\title{
Ground-Water Conditions in the Anza-Terwilliger Area, with Emphasis on the Cahuilla Indian Reservation, Riverside County, California, 1973-86
}

By Linda $R$. Woolfenden and Daniel J. Bright

\section{U.S. GEOLOGICAL SURVEY}

Water-Resources Investigations Report 88-4029

Prepared in cooperation with the

U.S. BUREAU OF INDIAN AFFAIRS

군
1
g
$\circ$
in 
DEPARTMENT OF THE INTERIOR

DONALD PAUL HODEL, Secretary

U.S. GEOLOGICAL SURVEY

Dallas L. Peck, Director

For additional information write to:

District Chief

U.S. Geological Survey

Federal Building, Room W2234

2800 Cottage Way

Sacramento, CA 95825
Copies of this report

can be purchased from:

U.S. Geological Survey

Books and Open-File Reports Section

Box 25425, Building 810

Federal Center

Denver, CO 80225 


\section{CONTENTS}

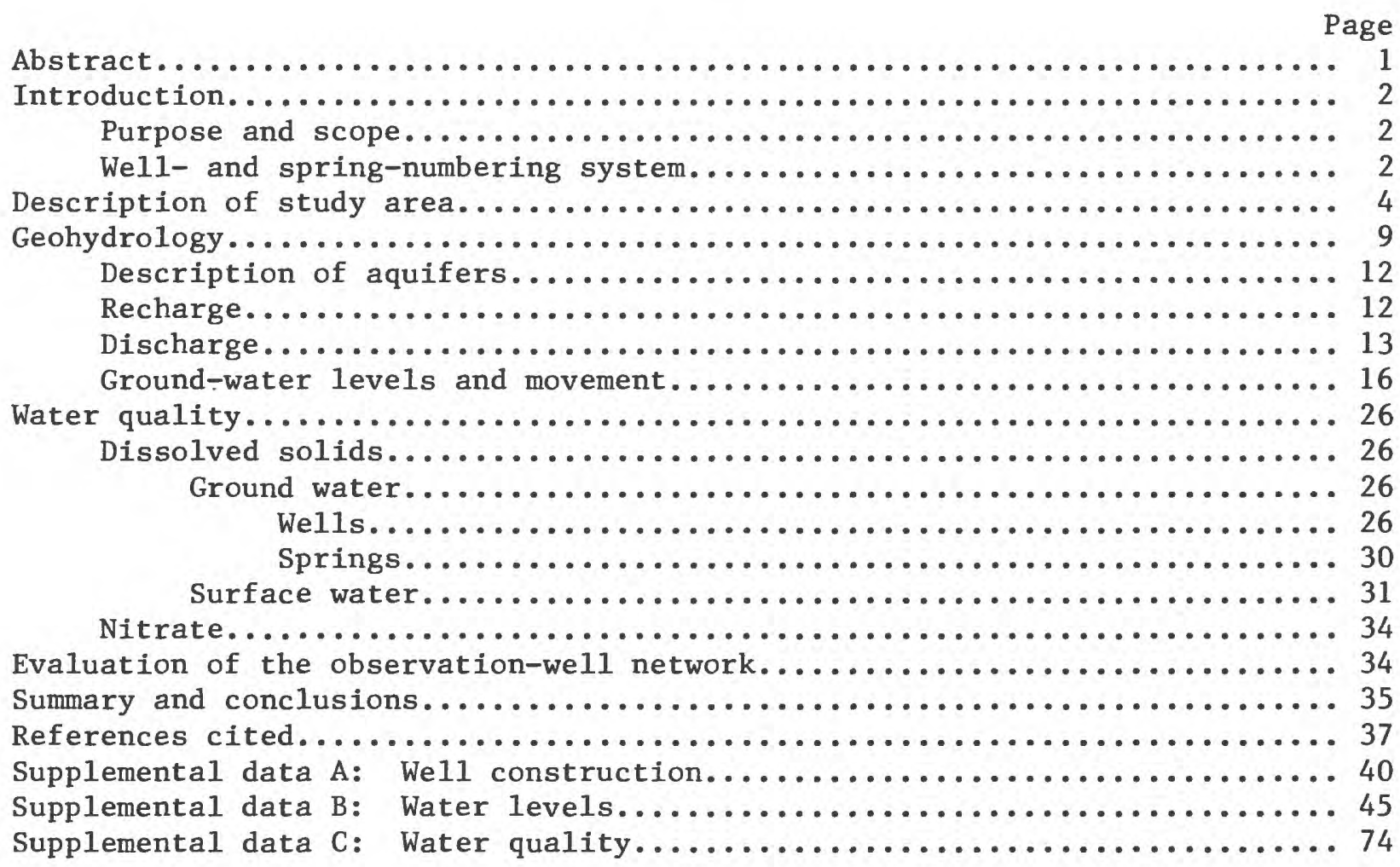

\section{ILLUSTRATIONS}

Figures 1-3. Maps showing:

1. Location of study area.................... 5

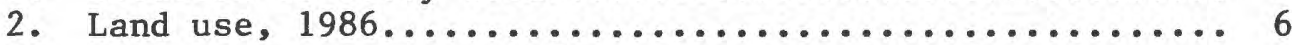

3. Geology and location of wells, springs, and surfacewater sampling sites..................... 10

4. Graphs showing cumulative departure from 1943-86 mean annual precipitation at Anza, and water-table altitudes in well

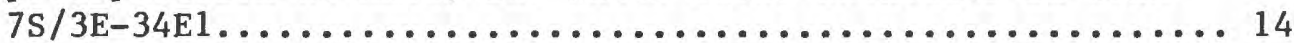

5-6. Maps showing altitude of the water table:

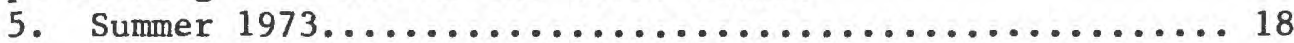

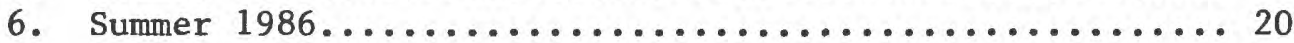

7. Hydrographs showing altitude of the water table in selected

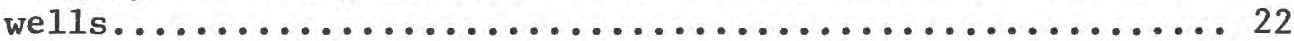

8-9. Maps showing:

8. Change in water-table altitudes between summer 1973

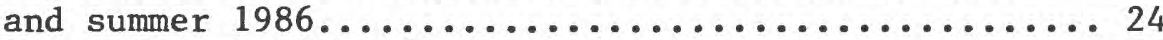

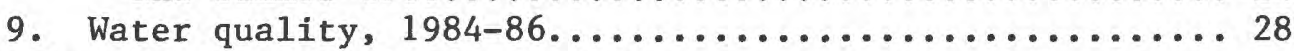

10. Graphs showing dissolved-solids concentration in water from

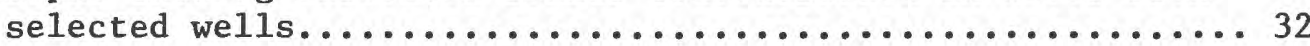




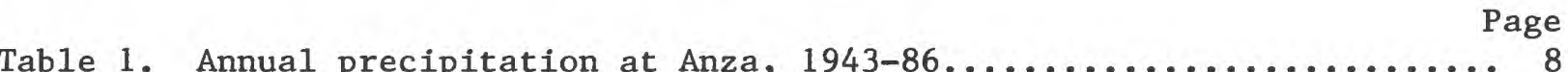

2. Changes in acreage for selected land uses, $1973-86 . \ldots \ldots \ldots \ldots . .9$

3. Estimated consumptive use of ground water, 1973 and $1986 \ldots \ldots \ldots 15$

4. Comparison of historical and 1984-86 dissolved-solids concentrations in water from selected wells.............. 31

\section{CONVERSION FACTORS}

The inch-pound system of units is used in this report. For readers who prefer metric (International System) units, the conversion factors for the terms used in this report are listed below:

Multiply inch-pound unit

acre

acre-foot (acre-ft)

acre-foot per year (acre-ft/yr)

foot ( $f t)$

gallon per day (gal/d)

gallon per minute (gal/min)

gallon per minute per foot

[(gal/min)/ft]

inch (in.)

mile (mi)

square mile $\left(\mathrm{mi}^{2}\right)$
$\underline{B y}$

0.4047

0.001233

0.001233

0.3048

0.003785

0.06309

0.2070

25.4

1.609

2.590

To obtain metric unit

hectare

cubic hectometer

cubic hectometer per annum meter

cubic meter per day

liter per second

liter per second per meter

millimeter

kilometer

square kilometer

\section{Abbreviations used:}

mg/L - milligram per 1iter

$\mu \mathrm{g} / \mathrm{L}$ - microgram per liter

$\mu \mathrm{S} / \mathrm{cm}$ - microsiemen per centimeter at $25^{\circ} \mathrm{Celsius.}$

\section{ALTITUDE DATUM}

In this report "sea level" refers to the National Geodetic Vertical Datum of 1929 (NGVD of 1929)--a geodetic datum derived from a general adjustment of the first-order level nets of both the United States and Canada, formerly called Sea Leve1 Datum of 1929. 


\author{
GROUND-WATER CONDITIONS IN THE ANZA-TERWILLIGER AREA, \\ WITH EMPHASIS ON THE CAHUILLA INDIAN RESERVATION, \\ RIVERSIDE COUNTY, CALIFORNIA, 1973-86
}

By Linda R. Woolfenden and Daniel J. Bright

\title{
ABSTRACT
}

Demand for ground water in the 96-square mile Anza-Terwilliger area has increased in recent years because of population growth and agricultural development. During 1950-73, the water table declined and chemical analyses showed elevated concentrations of nitrate in water from five wells. The U.S. Bureau of Indian Affairs is concerned that continued growth will cause greater water-table declines and further degrade ground-water quality at the Cahuilla Indian Reservation.

Water-leve1 measurements indicate that, as in previous years, ground water normally moves toward streams in Anza and Terwilliger Valleys. However, during the summer, when pumping is at a maximum, ground water moves toward two areas of ground-water withdrawals in Anza Valley. One area where ground-water levels were lowered extends to the northern boundary of Cahuilla Indian Reservation.

Ground-water use during 1986 is estimated at 10,000 acre-feet, 6,000 acre-feet more than in 1973. The water table, however, generally has risen since 1973. The rise is due to the wet climatic conditions that generally have prevailed since 1976, resulting in above average recharge.

Dissolved-solids concentrations in water from the wells sampled ranged from 184 to 1,320 milligrams per liter. During 1986, water from 14 wells of the 38 locations sampled had dissolved-solids concentrations greater than 500 milligrams per liter, which is the U.S. Environmental Protection Agency recommended limit for public water supplies. Two of these 14 wells are on Cahuilla Indian Reservation.

Nitrate (as nitrogen) concentrations ranged from 0.0 to 170 milligrams per liter. Water from 8 wells of the 38 locations sampled had nitrate concentrations higher than the U.S. Environmental Protection Agency recommended limit of 10 milligrams per liter. None of these eight wells are on Cahuilla Indian Reservation.

The observation-well network was found to be generally adequate for detecting changes in water levels and water quality, but the addition of one water-level observation well and two water-quality observation wells would further enhance its effectiveness. 
Demand for ground water in the rural Anza-Terwilliger area has increased significantly because of population growth and establishment of irrigated crops on previously unirrigated land. A previous study based on 1973 information (Moyle, 1976) identified water-table depressions adjacent to the Cahuilla Indian Reservation that had increased the hydraulic gradient and caused the ground water beneath the reservation to flow toward the depressions. The study also indicated that water from five wells outside the reservation contained concentrations of nitrate that exceeded the limit recommended by the U.S. Environmental Protection Agency for public water supplies. The U.S. Bureau of Indian Affairs is concerned that continued population growth and increases in irrigation will cause greater water-table declines and further degradation of the quality of ground water at Cahuilla Indian Reservation.

\section{Purpose and Scope}

This report, prepared in cooperation with the U.S. Bureau of Indian Affairs, evaluates the present (1986) occurrence, movement, and discharge of ground water, and documents changes in chemical quality that have occurred in the Anza-Terwilliger area during 1973-86. The present observation-well network, established in 1973, is evaluated to determine its effectiveness in detecting water-level and water-quality changes.

The study involved: (1) updating the well inventory and measuring water levels in 100 wells; (2) updating water-use data from current land-use and population data; and (3) sampling 30 wells, 5 springs, and 3 locations along Cahuilla Creek for chemical analyses.

\section{We11- and Spring-Numbering System}

Wells and springs are numbered according to their location in the rectangular system for the subdivision of public land. For example, in the number $7 \mathrm{~S} / 2 \mathrm{E}-28 \mathrm{Q} 1$ the part of the number preceding the slash indicates the township (T. $7 \mathrm{~S}$.$) , the part between the slash and the hyphen indicates the range (R.$ 2 E.), the number between the hyphen and the letter indicates the section (sec. 28), and the letter indicates the 40-acre subdivision of the section. Within the 40-acre tract wells are numbered serially, as indicated by the final digit. Thus, well $7 \mathrm{~S} / 2 \mathrm{E}-28 \mathrm{Q} 1$ is the first well to be listed in the SW1/4SE1/4 sec. 28, T. 7 S., R. 2 E., San Bernardino base line and meridian as shown on the facing page. The numbering of springs is the same as for wells except that an $\mathrm{S}$ is placed between the 40-acre letter and the final digit (as in $7 \mathrm{~S} / 2 \mathrm{E}-26 \mathrm{GS} 1$ ). 


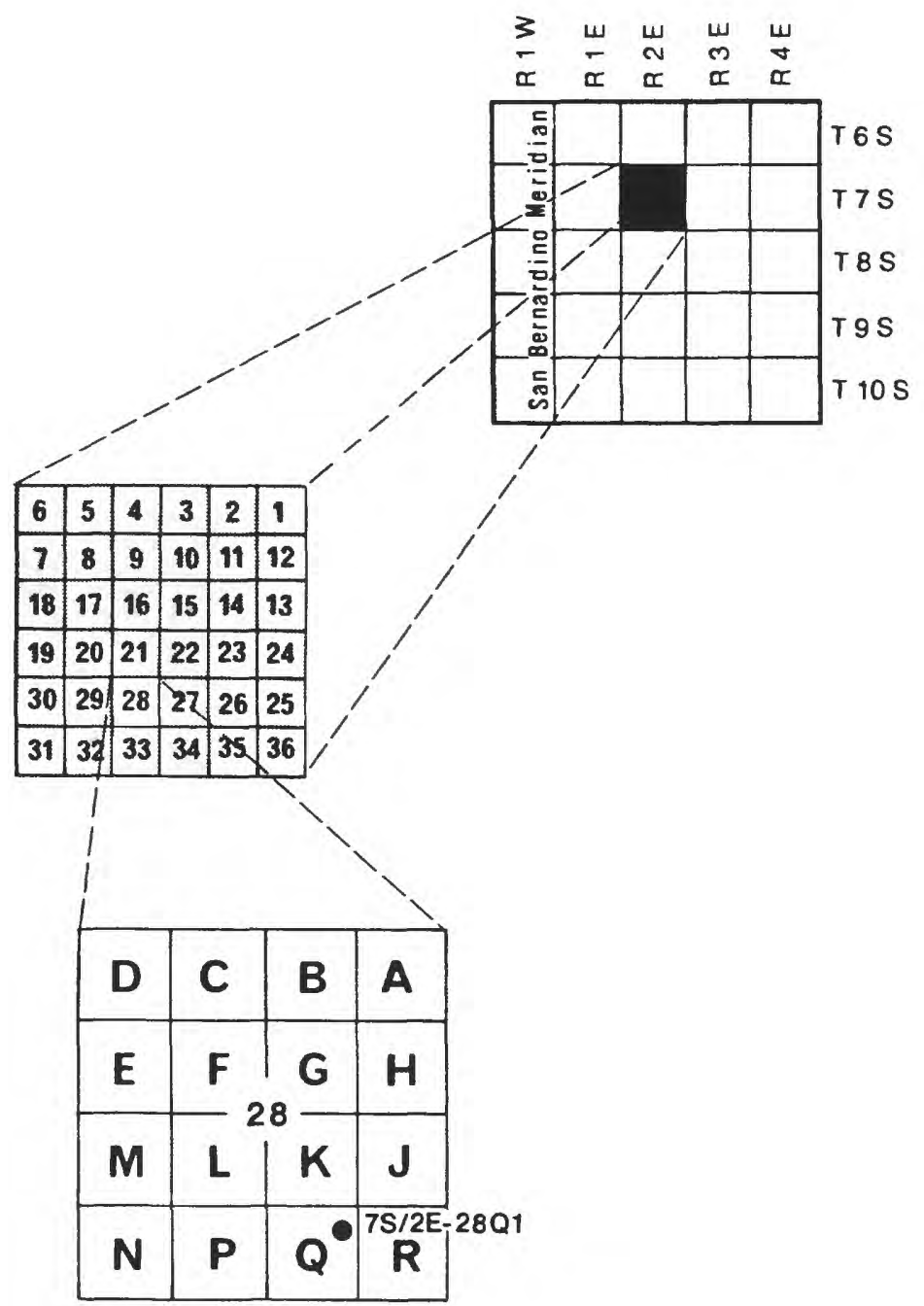

We11- and Spring-Numbering Diagram 
The Anza-Terwilliger study area (fig. 1) is in Riverside County about 90 miles southeast of Los Angeles. The $96-\mathrm{mi}^{2}$ study area is in the upper part of the Santa Margarita River and Coyote Creek hydrologic basins and includes the Cahuilla Indian Reservation. The Anza-Terwilliger area is drained by two ephemeral creeks, Cahuilla Creek and Coyote Creek. Anza, Burnt, Cahuilla, Durasna, and Durasno Valleys are drained by Cahuilla Creek (fig. 2). These valleys consist of $82 \mathrm{mi}^{2}$ and are designated the Anza area in this report. Terwilliger Valley, drained by Coyote Creek, consists of $14 \mathrm{mi}^{2}$ and is designated the Terwilliger area. The $29-\mathrm{mi}^{2}$ Cahuilla Indian Reservation extends into both the Anza and Terwilliger areas.

The main aquifer is composed of unconsolidated alluvial deposits that are bounded by consolidated rocks in the San Jacinto Mountains on the east and northeast, Cahuilla Mountain on the northwest, and low hills on the south. The alluvial deposits are dissected near the mountains, resulting in an undulating topography. Toward the center of the valleys, the deposits are less dissected and the relief is lower. The Anza-Terwilliger area slopes from east to west, and land-surface altitudes range from 6,890 feet above sea level on Thomas Mountain at the northern edge of the study area to 2,260 feet in the west where Cahuilla Creek exits the study area.

The study area has a semiarid climate, with warm, dry summers and cool winters. Most precipitation, partly snow, occurs during November-April; the rest of the precipitation, generally insignificant in comparison, occurs as scattered summer thundershowers. Precipitation data were collected at Anza by the California Department of Forestry from January 1943 to December 1986. Average annual precipitation for the period of record is 14.51 inches (table 1). Monthly precipitation throughout the period of record ranged from 0 inches for several months to a high of 11.61 inches in February 1980.

The current (1986) population of the study area is about 4,000. Of this total, about 50 people reside on Cahuilla Indian Reservation (Eugene Madrigal, business manager, Cahuilla Indians, oral commun., 1986) and about 1,300 reside near Anza, the principal town; the rest of the population is scattered throughout the study area.

The Anza-Terwilliger area is primarily an agricultural community. Figure 2 shows the distribution of land use throughout the study area. Land use was obtained from aerial photographs of 1984 and 1985 and was field checked in April 1986. Land-use categories include lake or reservoir, irrigated apple trees, irrigated potatoes, irrigated pasture, grain crops, ground water at land surface, and natural pasture (where ground water is within 10 feet of land surface). A large part of the study area is undefined and consists of residential areas, small businesses, unirrigated pasture, and brush. Residential and business areas are small compared to pasture and brush areas. 


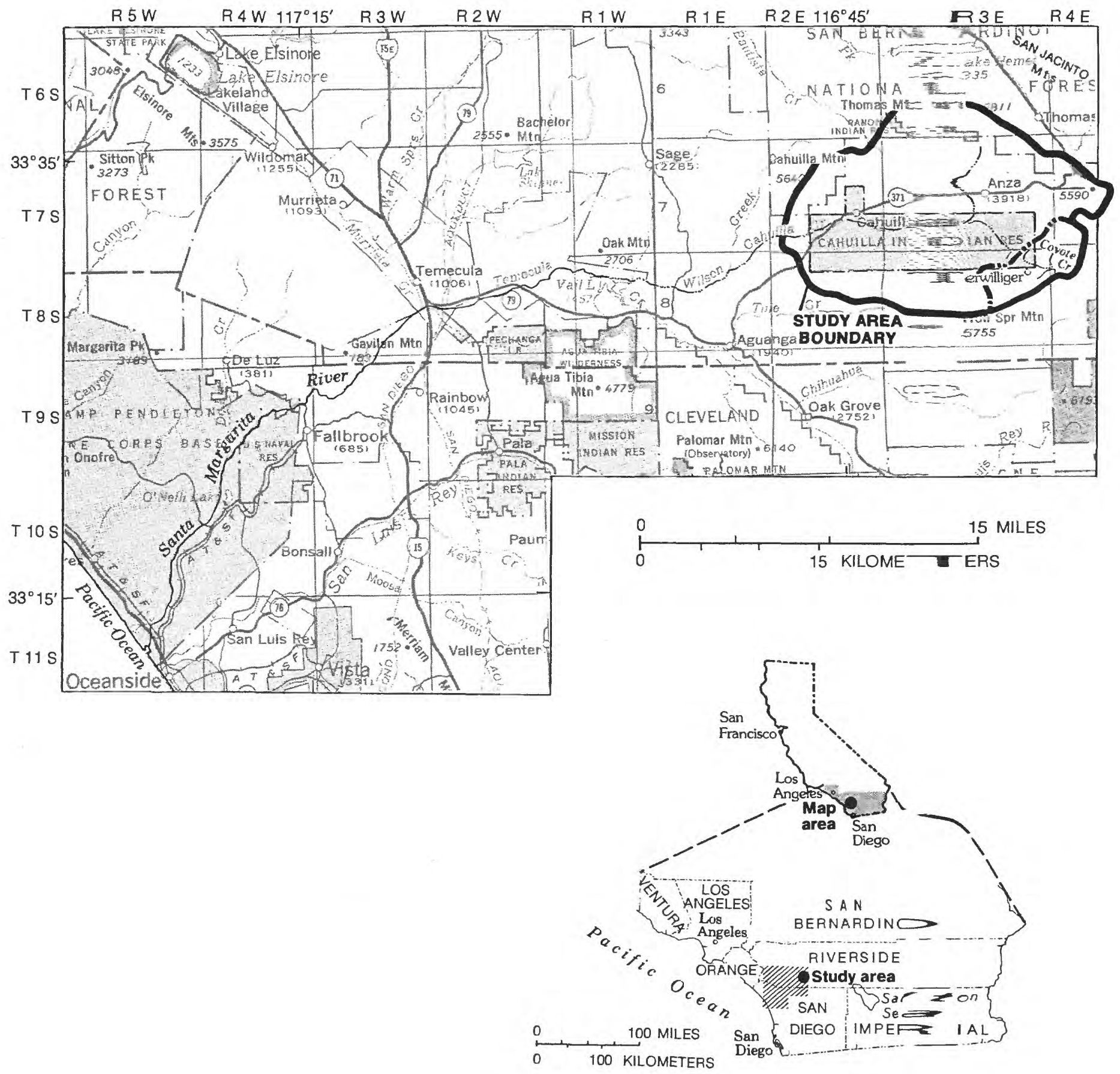

FIGURE 1.- Location of study area. 


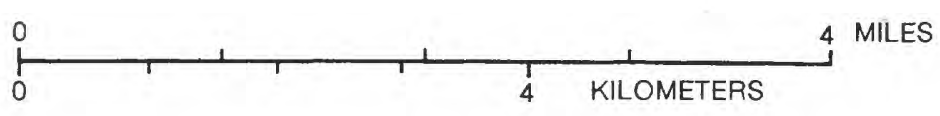

\section{EXPLANATION}

\begin{tabular}{|ll}
\hline & ANZA AREA \\
\hdashline$\because$ & TERWLLIGER AREA \\
& LAND USE - \\
LF & Landfill \\
& Irigated apple trees \\
& Irigated potatoes
\end{tabular}

Grain: barley, oats, or rye. Occasionally irrigated

Irrigated pasture

Natural pasture (Indicates ground water at or near land surface)

Lake or reservoir

Ground water at land surface

Note: Undefined area includes residential, small businesses, unirrigated pasture, and brush

\section{BOUNDARY OF SURFACE- WATER BASIN}

$7 \mathrm{C2}$ WELL AND NUMBER -

U.S. Geological Survey waterquality observation well

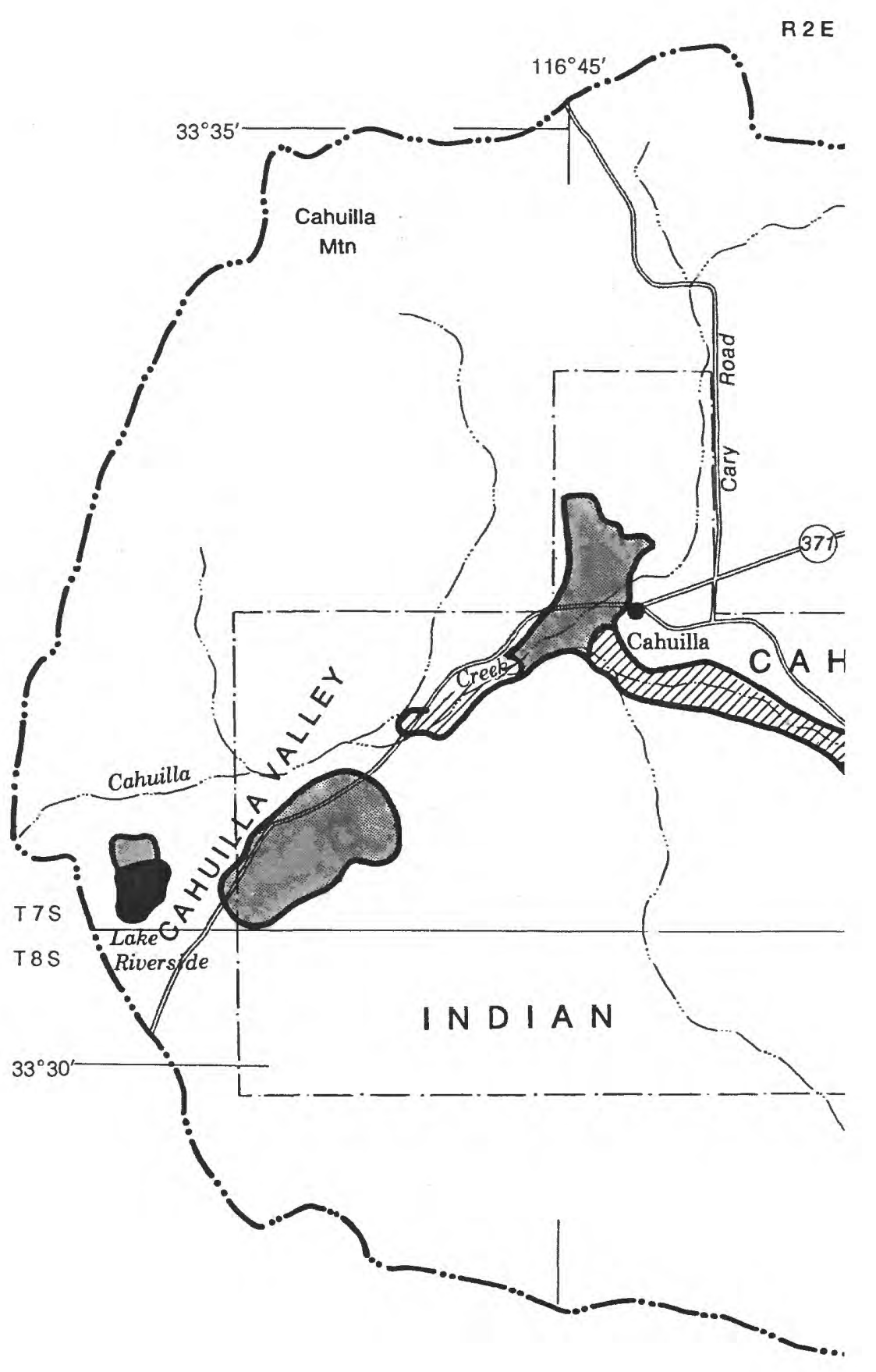

FIGURE 2.-Land use, 1986. 
Table 1.--Annual precipitation at Anza, 1943-86

[Data are from California State Department of Forestry station at Anza and are for calendar years. Precipitation: +, above average; -, below average]

\begin{tabular}{lccccc}
\hline Year & $\begin{array}{c}\text { Precipitation } \\
\text { (inches) }\end{array}$ & Year & $\begin{array}{c}\text { Precipitation } \\
\text { (inches) }\end{array}$ & Year & $\begin{array}{c}\text { Precipitation } \\
\text { (inches) }\end{array}$ \\
\hline 1943 & $22.38+$ & 1958 & $16.94+$ & 1973 & $11.66-$ \\
1944 & $15.51+$ & 1959 & $9.56-$ & 1974 & $11.07-$ \\
1945 & $17.50+$ & 1960 & $11.57-$ & 1975 & $11.07-$ \\
1946 & $14.11-$ & 1961 & $6.10-$ & 1976 & $17.15+$ \\
1947 & $9.72-$ & 1962 & $10.59-$ & 1977 & $13.69-$ \\
1948 & $7.19-$ & 1963 & $15.50+$ & 1978 & $29.07+$ \\
1949 & $8.09-$ & 1964 & $11.61-$ & 1979 & $16.49+$ \\
1950 & $7.28-$ & 1965 & $20.06+$ & 1980 & $29.86+$ \\
1951 & $25.21+$ & 1966 & $14.25-$ & 1981 & $11.47-$ \\
1952 & $17.46+$ & 1967 & $18.45+$ & 1982 & $23.47+$ \\
1953 & $5.65-$ & 1968 & $7.81-$ & 1983 & $27.97+$ \\
1954 & $11.82-$ & 1969 & $18.58+$ & 1984 & $16.09+$ \\
1955 & $9.96-$ & 1970 & $15.02+$ & 1985 & $10.52-$ \\
1956 & $5.24-$ & 1971 & $8.82-$ & 1986 & $16.54+$ \\
1957 & $21.44+$ & 1972 & $9.02-$ & & \\
\hline
\end{tabular}

Average annual precipitation $(1943-86) \ldots \ldots \ldots \ldots \ldots \ldots \ldots \ldots \ldots \ldots$

Lake Riverside is a manmade, private recreational lake in Cahuilla Valley. Throughout the study area there are several other manmade reservoirs that are used for irrigating crops. A constant water level is maintained in the reservoirs throughout the year by pumping of ground water (Jesse Pinales, foreman, Agri-Empire, oral commun., 1986). Water is pumped from high-capacity wells into the irrigation reservoirs and is used for irrigation of potatoes and, when necessary, of grain crops.

Apples are becoming an increasingly important crop in the study area. Minimum residential parcel size off the reservation is 2.5 acres, and many residents have small apple orchards. There are an estimated 30,000 apple trees in the study area (Anza Growers Association, oral commun., 1986). Most water for irrigation of these orchards is pumped from domestic wells. Virtually all the orchards are irrigated by drip systems that use water more efficiently than other methods because there is less loss from runoff, ponding, and evaporation.

Potatoes, the principal irrigated crop in the study area, are planted on selected parcels every third year. In the interim, grain crops (barley, oats, or rye) are grown. Potatoes are planted in April and harvested in October. During this time, irrigation is nearly continuous. The grain crops are occasionally irrigated. Most of the water for irrigation is pumped from the reservoirs and applied by sprinklers. Some land in the eastern part of Cahuilla Indian Reservation is used for growing potatoes and grain crops. 
A significant part of the study area is unirrigated pasture. Much of the unirrigated pasture on Cahuilla Indian Reservation is used to graze cattle. Some cattle also are grazed in Durasna Valley south of the reservation and in Cahuilla Valley west of the reservation. Water for cattle is provided by both springs and we1ls.

Table 2 shows the acreages of selected land uses for 1973 and 1986 . It is evident that there has been a significant increase in the amount of land devoted to growing both irrigated and grain crops. Of particular importance in terms of water use, is the tenfold increase in acreage of grain crops. The amounts of natural pasture and ground water at land surface also have increased significantly; these land uses are mainly in the western and central parts of the study area.

Most households and businesses in the study area obtain their water from individual domestic wells. There are two very small water districts in the study area--one in central Anza Valley and the other in the Table Mountain area of Terwilliger Valley.

Table 2.--Changes in acreage for selected land uses, 1973-86

\begin{tabular}{|c|c|c|c|c|}
\hline \multirow[t]{2}{*}{ Land use } & \multicolumn{2}{|c|}{$\begin{array}{c}\text { Total number } \\
\text { of acres }\end{array}$} & \multirow{2}{*}{$\begin{array}{l}\text { Change in } \\
\text { acreage } \\
(1973-86)\end{array}$} & \multirow{2}{*}{$\begin{array}{l}\text { Percent } \\
\text { difference } \\
\text { (rounded) }\end{array}$} \\
\hline & $\overline{1973}$ & 1986 & & \\
\hline Irrigated crops & 460 & 1,330 & 870 & 190 \\
\hline Natural pasture & 120 & 570 & 450 & 380 \\
\hline Lakes and reservoirs & 140 & 110 & -30 & -20 \\
\hline $\begin{array}{l}\text { Ground water at land } \\
\text { surface }\end{array}$ & 320 & 730 & 410 & 130 \\
\hline Grain crops & 210 & 2,270 & 2,060 & 980 \\
\hline
\end{tabular}

\section{GEOHYDROLOGY}

Geology of the study area has been described in previous reports by Moyle (1976) and Giessner and Mermod (1974). Igneous and metamorphic rocks crop out in the mountains and low hills of the study area. Hydraulic characteristics of the consolidated rocks are markedly different from those of the unconsolidated alluvial deposits that occur mainly along streams and other low-lying areas.

Geology and location of wells, springs, and surface-water sampling sites inventoried in 1985 and 1986 are shown in figure 3. Well-construction data for sites visited during 1985-86 are given in Supplemental Data A. 


\section{EXPLANATION}
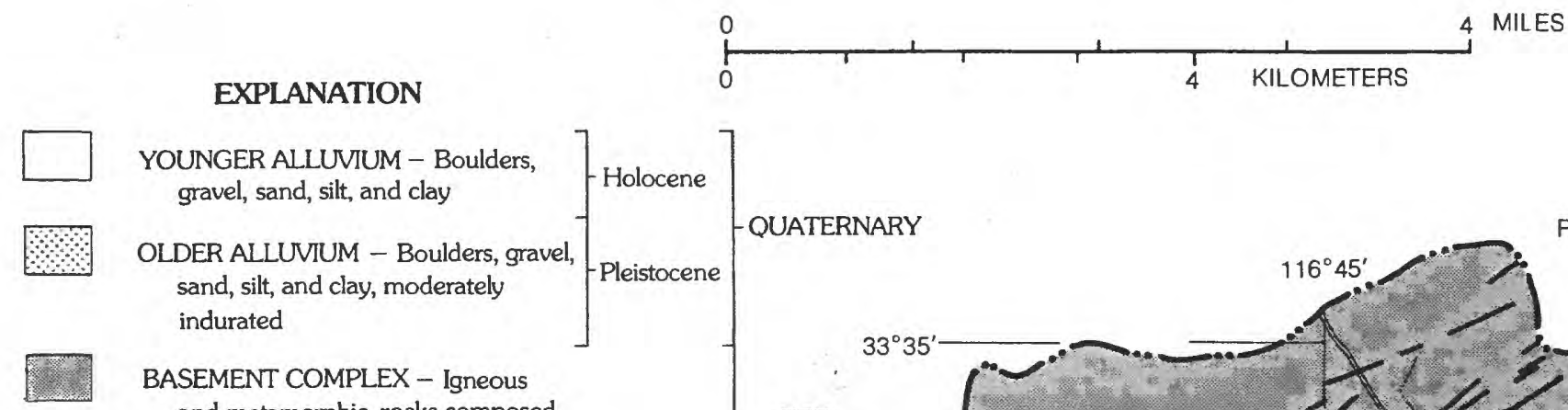

YOUNGER ALLUVIUM - Boulders, gravel, sand, silt, and clay

OLDER ALLUVIUM - Boulders, gravel, sand, silt, and clay, moderately indurated

BASEMENT COMPLEX - Igneous and metamorphic rocks composed of granite, tonalite, dionite, gneiss, hornblende and mica schists; contain inclusions and pegmatite dikes

\section{CONTACT}

FAULT - Dashed where approximately located, dotted where concealed

BOUNDARY OF SURFACE-WATER BASIN

$\nabla^{30 C C 1}$ SURFACE-WATER SAMPLING SITE AND NUMBER

$9 B 1$

$Q^{34 E 1}$ OBSERVATION WELL AND NUMBER (U.S. GEOLOGICAL SURVEY) $n^{27 H S 2}$ SPRING AND NUMBER
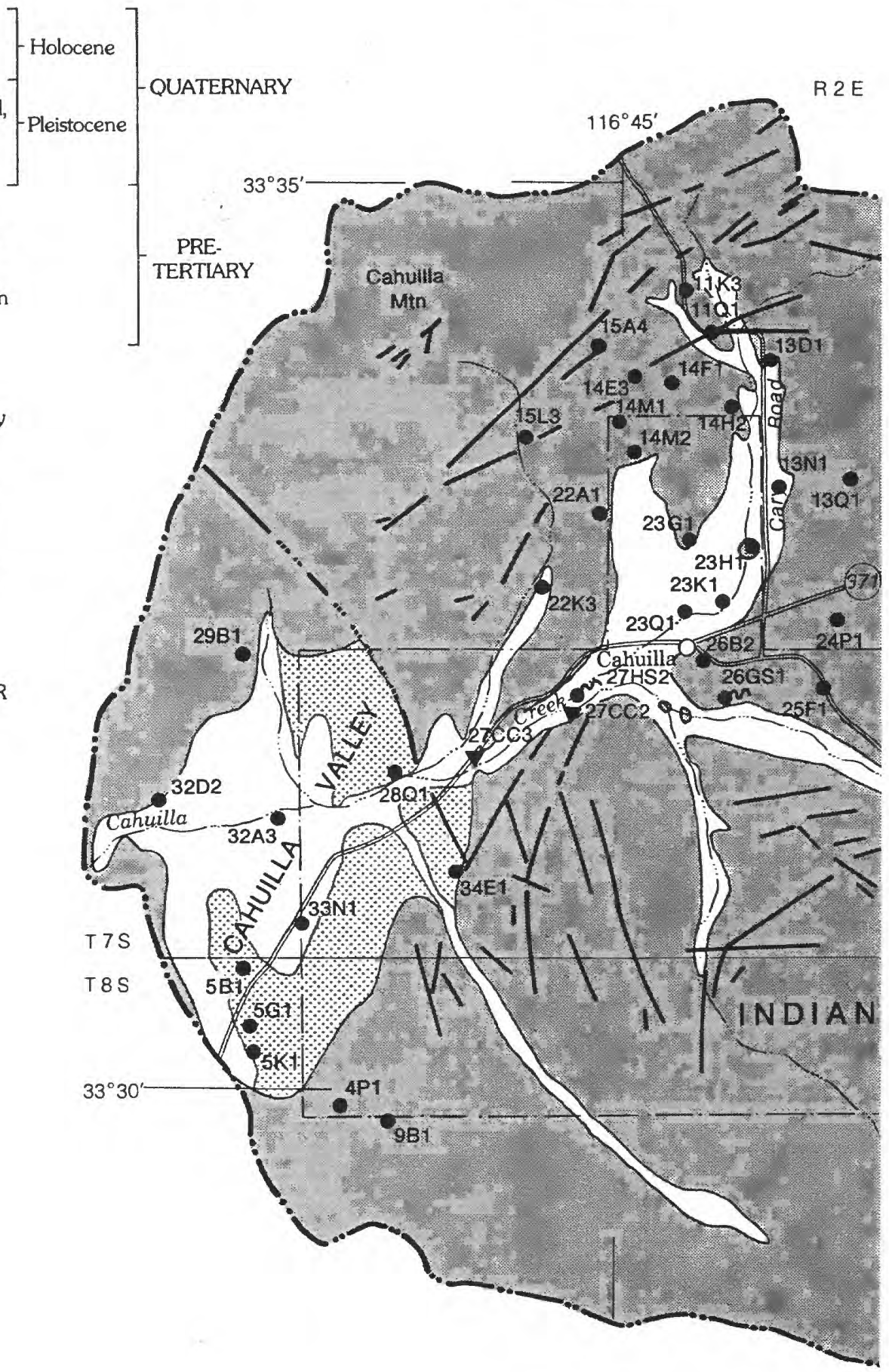

FIGURE 3.-Geology and location of wells, springs, and surface-water sampling sites. 


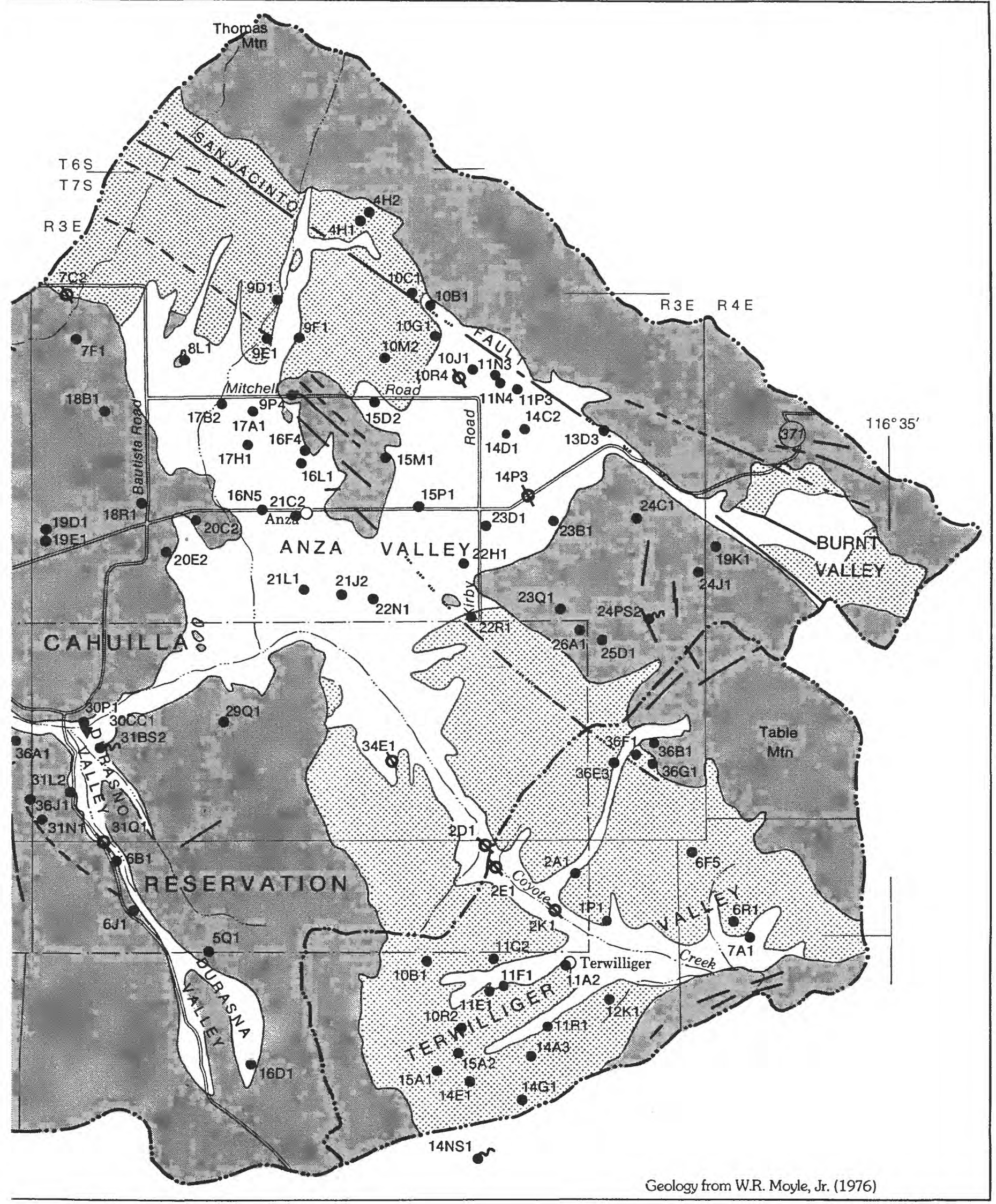




\section{Description of Aquifers}

Consolidated rocks of the mountains and hills are pre-Tertiary in age (fig. 3). The rocks consist of granite, diorite, tonalite, granite gneiss, diorite gneiss, hornblende schist, and mica schist and contain some xenoliths and pegmatite dikes (Moyle, 1976). Many domestic wells are drilled into the consolidated rocks throughout the study area. Small to moderate quantities (5 to $70 \mathrm{gal} / \mathrm{min}$ ) of water are obtained from wells that penetrate deeply weathered or fractured zones (Moyle, 1976). Specific capacities of wells perforated in the weathered or fractured rocks range from 0.1 to 2.4 ( $\mathrm{gal} / \mathrm{min}) / \mathrm{ft}$ of drawdown.

The older alluvium is of Pleistocene age and consists of moderately indurated boulders, grave1, sand, silt, and clay. Analysis of drillers' logs indicates that gravel (with occasional boulders) makes up 0 to 50 percent of this unit, sand 10 to 55 percent, and silt and clay 10 to 75 percent. The older alluvium contains many discontinuous clay lenses. The older alluvium is found mainly along mountain fronts and underlies the younger alluvium in most areas (fig. 3). The older alluvium is considered the principal aquifer of the study area, and most wells with large yields (200 to $1,100 \mathrm{gal} / \mathrm{min}$ ) obtain water from this unit. Specific capacities of wells perforated in the older alluvium range from 1.5 to 11.4 (gal/min)/ft of drawdown.

The younger alluvium consists of unconsolidated boulders, grave1, sand, silt, and clay of Holocene age. The younger alluvium is found mainly along stream channels and in the central part of Anza Valley (fig. 3). This unit is generally above the regional water table, but where it is saturated it yields water freely to wells (Moyle, 1976).

The main fault in the study area is the San Jacinto fault (fig. 3). It is a northwest-trending fault in the northeastern part of the study area. The fault acts as a barrier to ground-water flow, and water levels on either side of the fault differ as much as 400 feet.

An unnamed fault parallels the San Jacinto fault and extends from Anza Valley across the surface-water divide into Terwilliger Valley near the base of Table Mountain (fig. 3). Water-level measurements indicate that this fault probably is not a barrier to ground-water flow. Hydraulic characteristics of other faults in the area are unknown.

\section{$\underline{\text { Recharge }}$}

Ground water in the study area is derived entirely from precipitation. Precipitation in the Anza-Terwilliger area either moves downward into the fractures and weathered zones of the consolidated rocks, is held as soil moisture and consumed by evapotranspiration, infiltrates past the root zone and recharges unconsolidated deposits, runs off into stream channels, or recharges the ground-water system by seepage through the permeable streambeds. The quantity of ground water in storage and the water levels in wells are related 
to a cycle of extended periods of relatively wet and dry weather. A curve of cumulative departure from 1943-86 mean annual precipitation at Anza (see fig. 4a) shows wet and dry periods as follows:

\begin{tabular}{lccc}
\hline Type & Period & $\begin{array}{c}\text { Average } \\
\text { precipitation } \\
\text { (inches) }\end{array}$ & $\begin{array}{c}\text { Percentage above (+) } \\
\text { or below }(-) \text { 1943-86 } \\
\text { average precipitation }\end{array}$ \\
\hline Dry & $1943-75$ & 12.92 & -11.0 \\
Wet & $1976-86$ & 19.30 & +33.0 \\
\hline
\end{tabular}

Although the overa11 trend of the cumulative-departure curve during the dry period was decreasing, there were some minor reversals during this period. However, a major reversal of the trend, marking the beginning of the wet period, occurred in 1976, when precipitation was 2.64 inches above the 1943-86 mean of 14.51 inches.

As shown in figure 4, a close correlation exists between precipitation and measured water levels in the U.S. Geological Survey monitor we11 7S/3E-34E1. This unused well is in alluvium in the eastern part of the reservation. Although there is no continuous water-level record for most of the 1943-75 dry period, it can be seen that water-table altitudes in 1946 and 1951-54 were considerably higher than those in 1975. Water-table altitudes for 1960 and 1969 show a progressive lowering from 1951-54 to 1975 levels. The water table declined generally during 1946-75 because ground-water discharge exceeded recharge. During the 1976-86 wet period, water-table altitudes rose sharply as a result of increased recharge and a subsequent decrease in pumping.

Moyle (1976) estimated ground-water recharge in 1973 as 3,800 acre-ft. Average precipitation for 1973 was 11.66 inches (2.85 inches below the 1943-86 mean), so the long-term average rate of recharge may be higher than 3,800 acre-ft. No additional data were collected during this investigation to enable an accurate estimate of long-term recharge.

\section{Discharge}

Principal uses of ground water in 1986 were irrigation of crops, evapotranspiration from natural pasture, domestic supplies, livestock supplies, pumpage for maintenance of lakes and reservoirs, and evaporation in areas where ground water was at land surface. Table 3 shows estimated consumptive use for the above categories for 1973 and 1986. For the 1986 consumptive-use estimate, the total number of acres for each water-use category was estimated from figure 2. The population of the study area was estimated from Riverside County population data. The number of cattle and horses is assumed to be the same as in 1973. Consumptive-use rates and individual requirements were taken from Moyle (1976). Estimates of the consumptive use of ground water for 1973 and 1986 are rounded to one significant figure. 

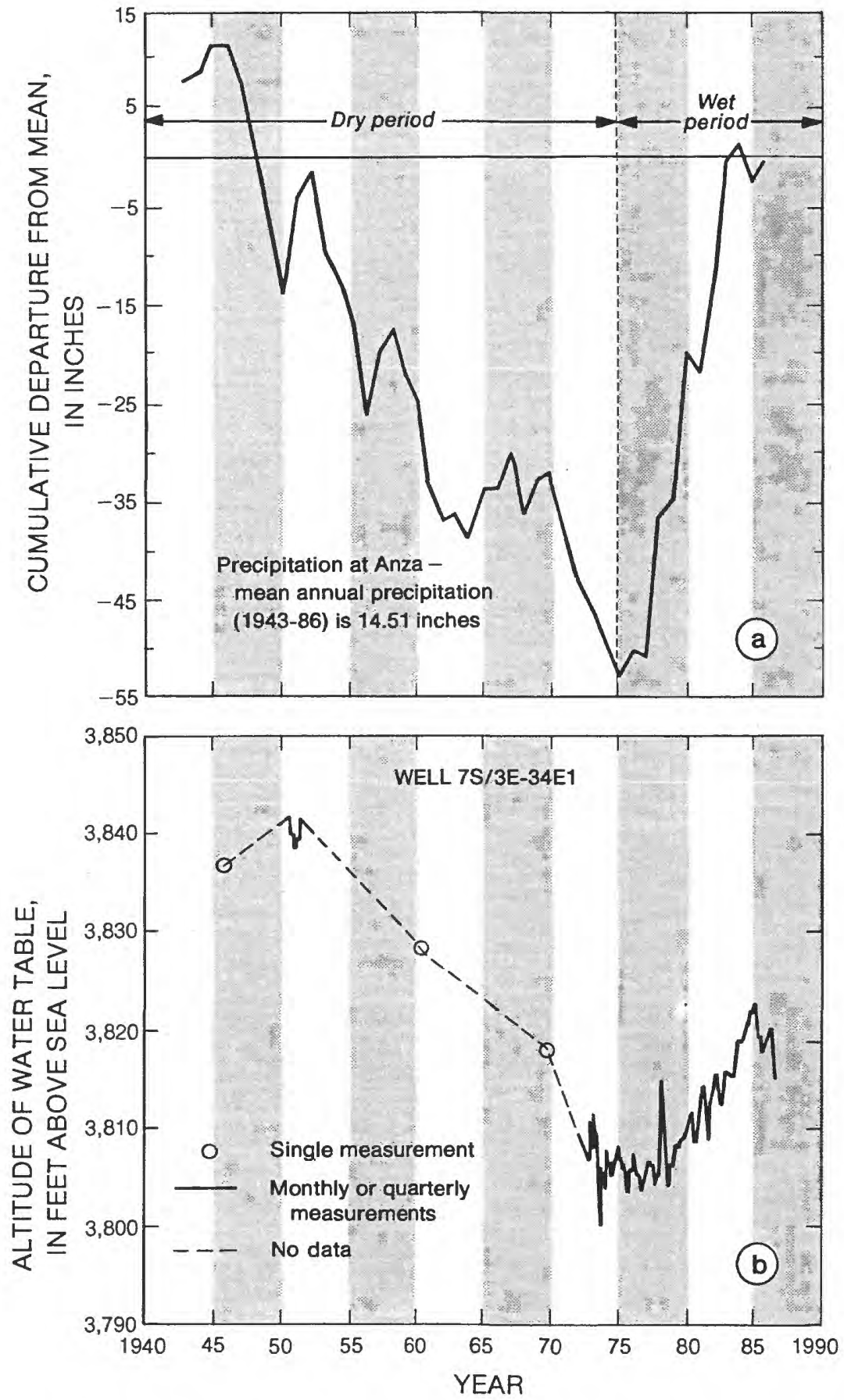

FIGURE 4.-(a) Cumulative departure from 1943-86 mean annual precipitation at Anza and (b) water-table altitudes in well 7S/3E-34E1. 
Table 3.--Estimated consumptive use of ground water, 1973 and 1986

\begin{tabular}{|c|c|c|c|c|c|c|}
\hline \multirow[t]{2}{*}{ Water use } & \multirow{2}{*}{$\begin{array}{c}\text { Total } \\
\text { number } \\
\text { of acres } \\
(1986)\end{array}$} & \multirow{2}{*}{$\begin{array}{l}\text { Individual } \\
\text { require- } \\
\text { ment, in } \\
\text { gallons } \\
\text { per day }\end{array}$} & \multirow{2}{*}{$\begin{array}{l}\text { Number } \\
\text { of } \\
\text { individuals } \\
\text { (1986) }\end{array}$} & \multirow{2}{*}{$\begin{array}{l}\text { Rate of } \\
\text { use, in } \\
\text { feet } \\
\text { per year }\end{array}$} & \multicolumn{2}{|c|}{$\begin{array}{c}\text { Consumptive use, } \\
\text { in acre-feet } \\
\text { per year }\end{array}$} \\
\hline & & & & & 1973 & 1986 \\
\hline Irrigated crops & 1,330 & -- & -- & 2.1 & 970 & 2,790 \\
\hline $\begin{array}{l}\text { Evaporation from } \\
\text { natural pasture }\end{array}$ & 570 & -- & -- & 3.5 & 420 & 2,000 \\
\hline Domestic use & -- & 125 & 4,000 & -- & 140 & 560 \\
\hline Cattle and horses & -- & 15 & 500 & -- & 10 & 10 \\
\hline $\begin{array}{l}\text { Evaporation from } \\
\text { lakes and reser- } \\
\text { voirs }\end{array}$ & 110 & -- & -- & 5.3 & 740 & 580 \\
\hline $\begin{array}{l}\text { Evaporation from } \\
\text { ground water at } \\
\text { land surface }\end{array}$ & 730 & -- & -- & 5.3 & 1,670 & 3,870 \\
\hline $\begin{array}{l}\text { Supplemental water } \\
\text { on grain crops }\end{array}$ & 2,270 & -- & -- & 1.0 & 210 & 2,270 \\
\hline $\begin{array}{l}\text { Estimated cor } \\
\text { use of grou }\end{array}$ & $\begin{array}{l}\text { nsumptiv } \\
\text { und wate }\end{array}$ & 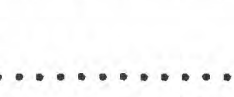 & & & 4,000 & ${ }^{1} 10,000$ \\
\hline
\end{tabular}

${ }^{1}$ Rounded to one significant figure.

The irrigated-crops category in table 3 includes both potatoes and apples. The total number of acres has increased by 190 percent since 1973 (table 2). Consumptive use for crops in 1986 was 1,820 acre-ft/yr more than in 1973.

Natural pastures are areas where ground water is within about 10 feet of land surface. Water is consumed from natural pasture by evapotranspiration, which includes transpiration of water by growing vegetation and water evaporated from soil. Natural pasture increased by 380 percent (table 2) during 1973-86, probably due to a rising water table. This resulted in an increase in consumptive use of $1,580 \mathrm{acre-ft/yr}$.

Domestic water supplies include those for household and business uses. Consumptive use for this category is based on total population, which increased by 400 percent during 1973-86. This accounts for an increase of $420 \mathrm{acre-ft} / \mathrm{yr}$ in consumptive use.

Consumptive use for cattle and horses is based on the number of animals. The number of cattle and horses is assumed to have remained the same during 1973-86, and the total consumptive use (10 acre-ft) for this category is relatively small in comparison with other use categories. 
Pumpage for maintenance of lakes and reservoirs is estimated from pan evaporation rates $(5.3 \mathrm{ft} / \mathrm{yr})$. These lakes and reservoirs are filled with ground water to maintain a constant level. Both Lake Riverside and the irrigation reservoirs are full year-round. Water is pumped into the irrigation reservoirs from February through October, and the water levels are maintained by precipitation from November through January (Jesse Pinales, foreman, Agri-Empire, oral commun., 1986). The area of lakes and reservoirs in 1986 was 20 percent less than in 1973 (table 2), resulting in a decrease of 160 acre-ft/yr in consumptive use.

In areas of ground water at land surface, there is standing water and the water table is at or above land surface. Estimation of consumptive use for this category also is based on pan evaporation rates. Total area for this category increased by 130 percent during 1973-86 (table 2). This resulted in an increase in consumptive use of 2,200 acre-ft/yr.

Grain crops are irrigated only when there is insufficient precipitation for their needs. This land-use category had the largest increase in acreage during 1973-86, 980 percent (table 2). Consumptive use for grain crops increased by 2,060 acre-ft/yr.

Estimated total consumptive use in 1986 was 10,000 acre-ft/yr, an increase of 6,000 acre-ft/yr since 1973. The increase in agricultural activities accounts for 49 percent of the additional consumptive use of ground water during 1973-86. Forty-six percent of the additional consumptive use during 1973-86 is due to the increase in the quantity of ground water evaporated in areas where the water table is near or above land surface. Pumpage for domestic supplies accounts for 5 percent of the increase.

\section{Ground-Water Levels and Movement}

Prior to 1950 when the water table in the study area was unaffected by pumping, movement of ground water was toward major streams in Anza and Terwilliger Valleys (Moyle, 1976). The water-table surface sloped from its highest altitudes in the consolidated rocks in the mountains toward Cahuilla and Coyote Creeks. Over the long term, ground-water discharge equaled recharge, and the system was in a steady-state condition.

Figures 5 and 6 show altitude of the water table for summer 1973 and summer 1986, respectively. The water-table maps are based on water-level measurements in we1ls that are completed at varying depths in the ground-water system. However, the limited data indicate that hydraulic head does not vary significantly with depth, and that the measured water levels closely approximate the altitude of the water table in both the consolidated rocks and alluvium. Historical water levels for wells measured in 1986 are given in Supplemental Data B. 
Figure 5 shows the altitude of the water table during summer 1973. Water-table altitudes were determined from land-surface altitudes estimated from topographic maps and original water-level measurements made in July and August 1973. Two areas in the alluvium are shown where ground water moved toward water-table depressions. One of the depressions was in Cahuilla Indian Reservation, and another was just north of the reservation. Grain crops were planted in both areas. Supplemental irrigation for crops probably was more intense than normal during 1973 because of the below-average precipitation.

Figure 6 shows the altitude of the water table during the summer 1986 pumping season. Water-table altitudes are based on water-level measurements made in July and August 1986, and the altitudes range from 3,413 feet in well $7 \mathrm{~S} / 3 \mathrm{E}-32 \mathrm{D} 2$ to 4,757 feet in we11 7S/3E-4H2. There are two areas in the alluvium where ground water flowed toward water-table depressions. One depression, in central Anza Valley, extended to the northern boundary of Cahuilla Indian Reservation. This depression was centered around the largest irrigation reservoir in the study area. The other water-table depression was at the northeast edge of Anza Valley where potatoes and grains were grown.

Hydrographs for four wells monitored by the U.S. Geological Survey are shown in figure 7. Two we1ls, $8 \mathrm{~S} / 3 \mathrm{E}-2 \mathrm{D} 1$ and $8 \mathrm{~S} / 3 \mathrm{E}-2 \mathrm{~K} 1$, are in the southeastern part of Cahuilla Indian Reservation in the alluvium (fig. 3). The hydrograph for wel1 8S/3E-2D1, an irrigation well, shows water-table altitudes for 1960 , 1969, and 1973-86. The water table in 1969 was much lower than in 1960 because of the dry conditions and increased ground-water use that prevailed during that period. Declines were less sharp between 1973 and 1977 because a wet period began in 1976. The water table then rose slightly during 1977-86. This corresponded to periods of higher-than-average precipitation, particularly in 1978 (19.07 inches) and 1980 (19.86 inches). The hydrograph for wel1 $8 \mathrm{~S} / 3 \mathrm{E}-2 \mathrm{~K} 1$, an unused we11, shows the same trend during 1973-86, except that the declines in this well were steeper between 1973 and 1977.

Water-table altitudes for we11s $7 \mathrm{~S} / 3 \mathrm{E}-7 \mathrm{C} 2$ and $7 \mathrm{~S} / 3 \mathrm{E}-31 \mathrm{Q} 1$ also show the effects of wet and dry periods. The hydrograph for we11 7S/3E-7C2 shows a fairly stable water table during 1969-76, but the water table rose markedly during 1977-86. We11 7S/3E-7C2 is a domestic well in the north end of the study area in alluvium and consolidated rocks (fig. 3). Well 7S/3E-31Q1 is a domestic well in the central part of Cahuilla Indian Reservation in a narrow strip of alluvium. The hydrograph for this well shows that the water table was relatively constant until 1977 when it rose sharply because of the higher-than-average precipitation.

Figure 8 shows changes in water-table altitudes between the summer of 1973 and the summer of 1986 at 39 wells. All water-level measurements were made in nonpumping wells in the middle of the summer pumping season when most irrigation pumps were running and maximum stress was imposed on the ground-water system. 


\section{EXPLANATION}

UNCONSOLIDATED DEPOSITS -

Younger and older alluvium of

Quaternary age

CONSOLIDATED ROCKS - Basement complex of pre-Tertiary age

\section{CONTACT}

FAULT - Dashed where approximately located, dotted where concealed

\section{BOUNDARY OF SURFACE-WATER} BASIN

WELL - Measured for water-table altitude, summer 1973

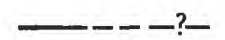

WATER-TABLE CONTOUR - Shows altitude of water table, in feet. Dashed where approximately located; queried where uncertain. Hachures indicate depression. Contour interval variable. Datum is sea level
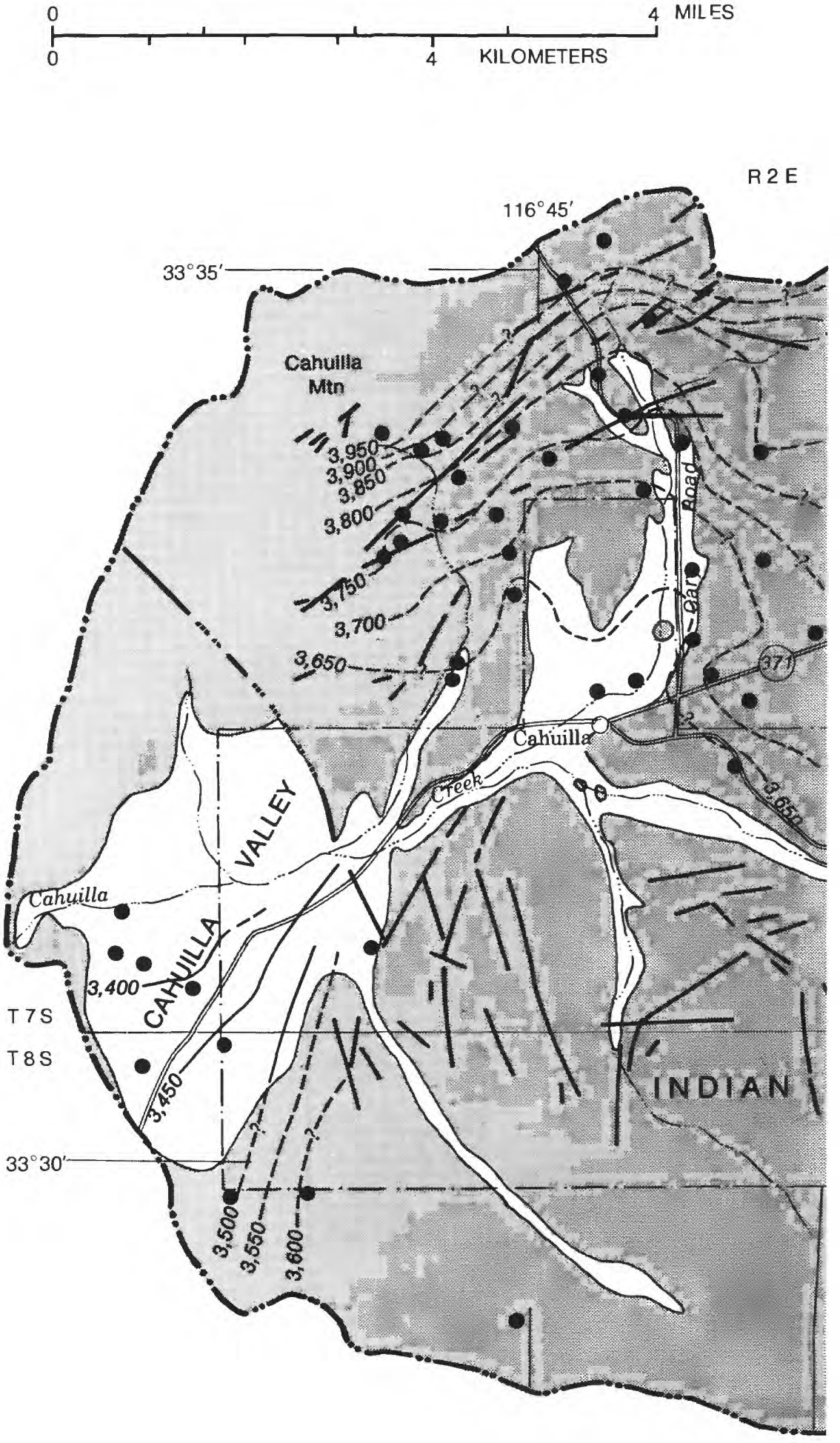

FIGURE 5. - Altitude of the water table, summer 1973. 


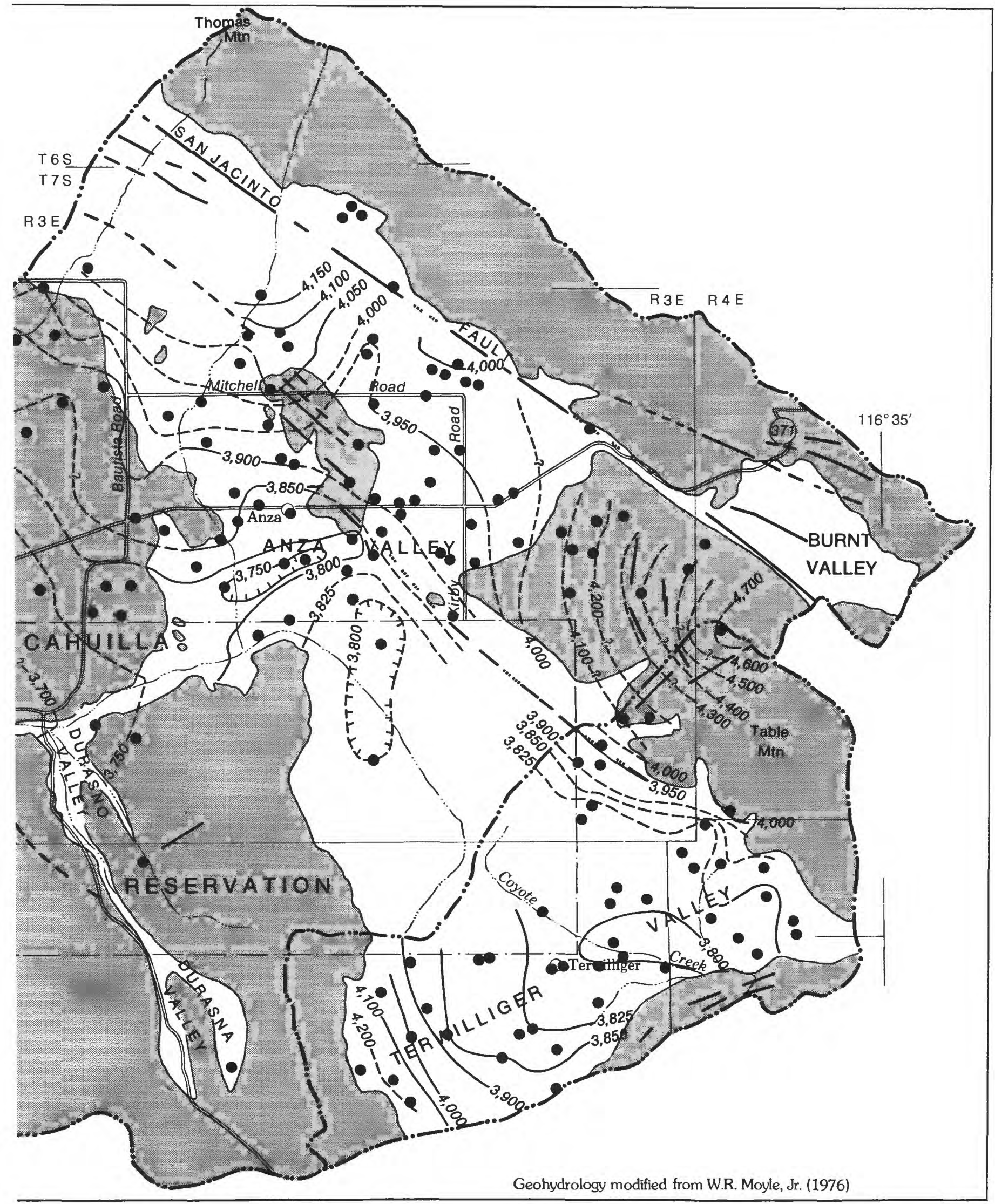




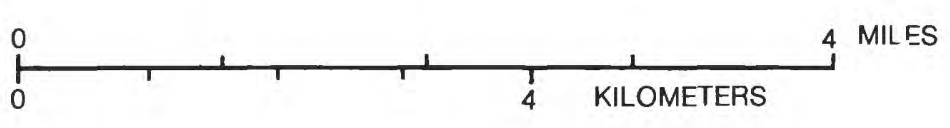

\section{EXPLANATION}

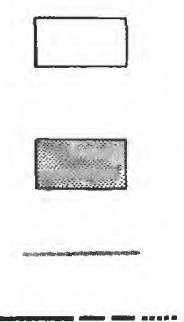

UNCONSOLIDATED DEPOSITS -

Younger and older alluvium of Quaternary age

CONSOLIDATED ROCKS - Basement complex of pre-Tertiary age

CONTACT

FAULT - Dashed where approximately located, dotted where concealed

BOUNDARY OF SURFACE-WATER BASIN

WELL - Measured for water-table altitude, summer 1986

WATER-TABLE CONTOUR - Shows altitude of water table, in feet. Dashed where approximately located; queried where uncertain. Hachures indicate depression. Contour interval variable. Datum is sea level

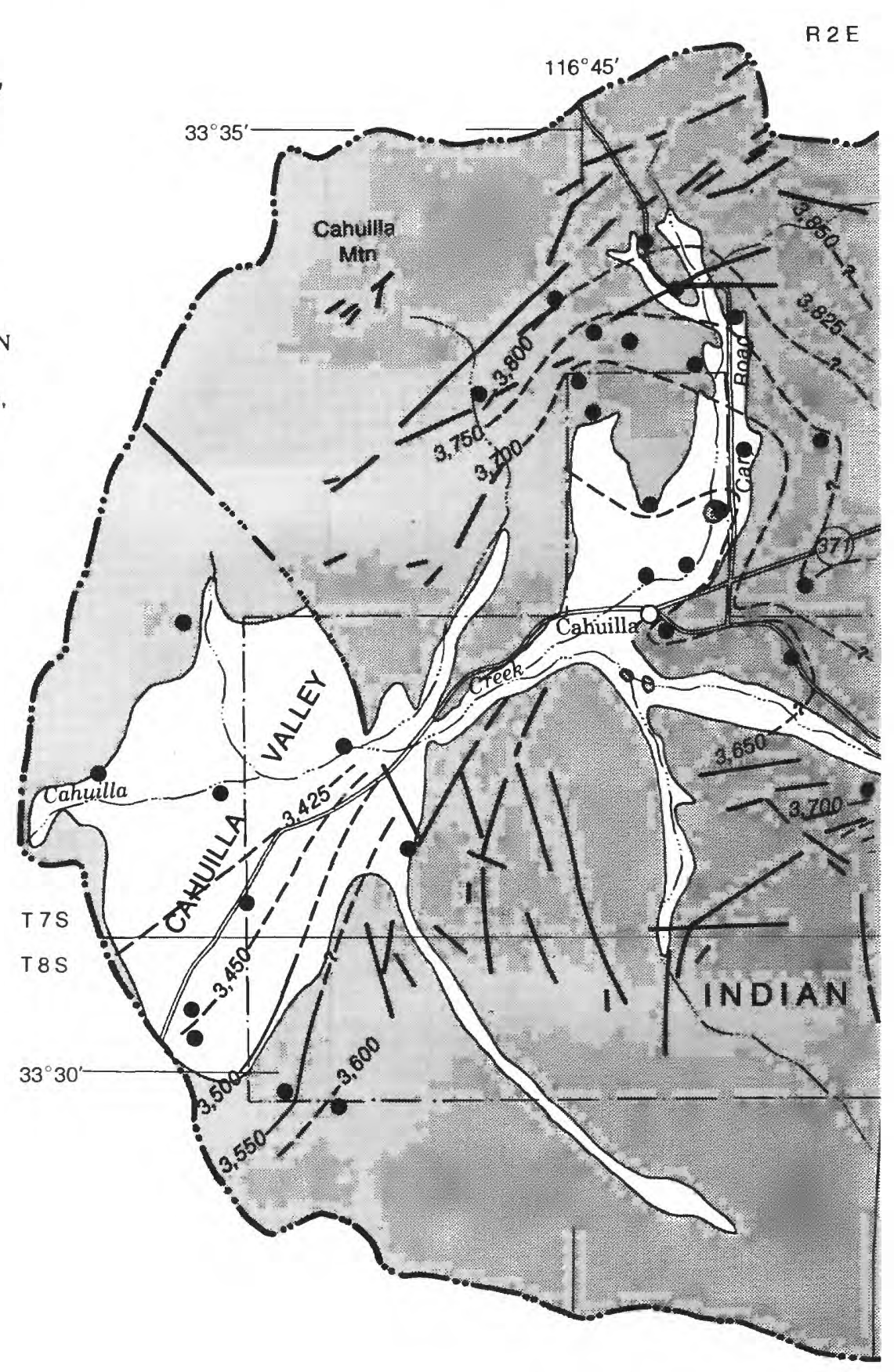

FIGURE 6.-Altitude of the water table, summer 1986. 


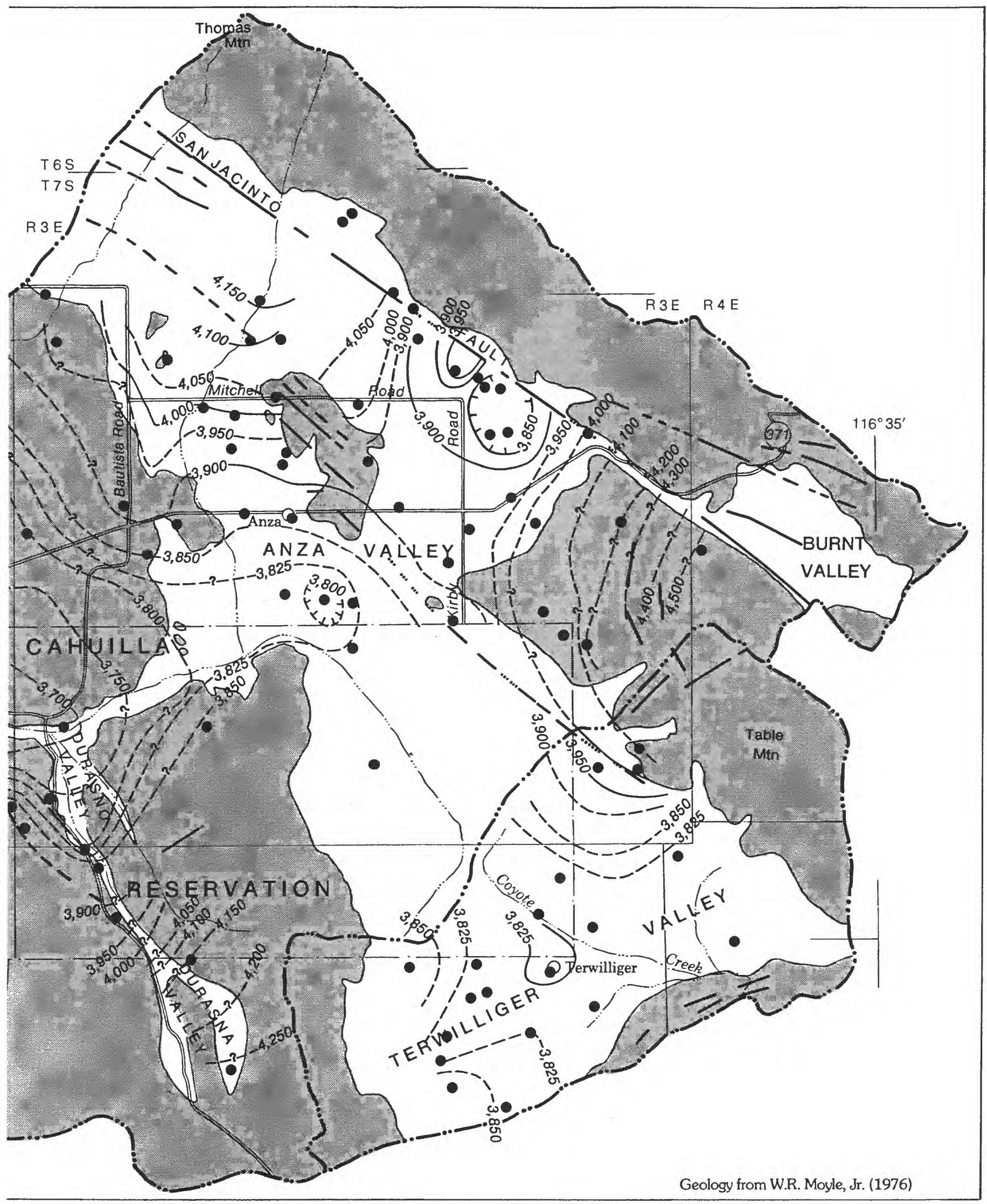




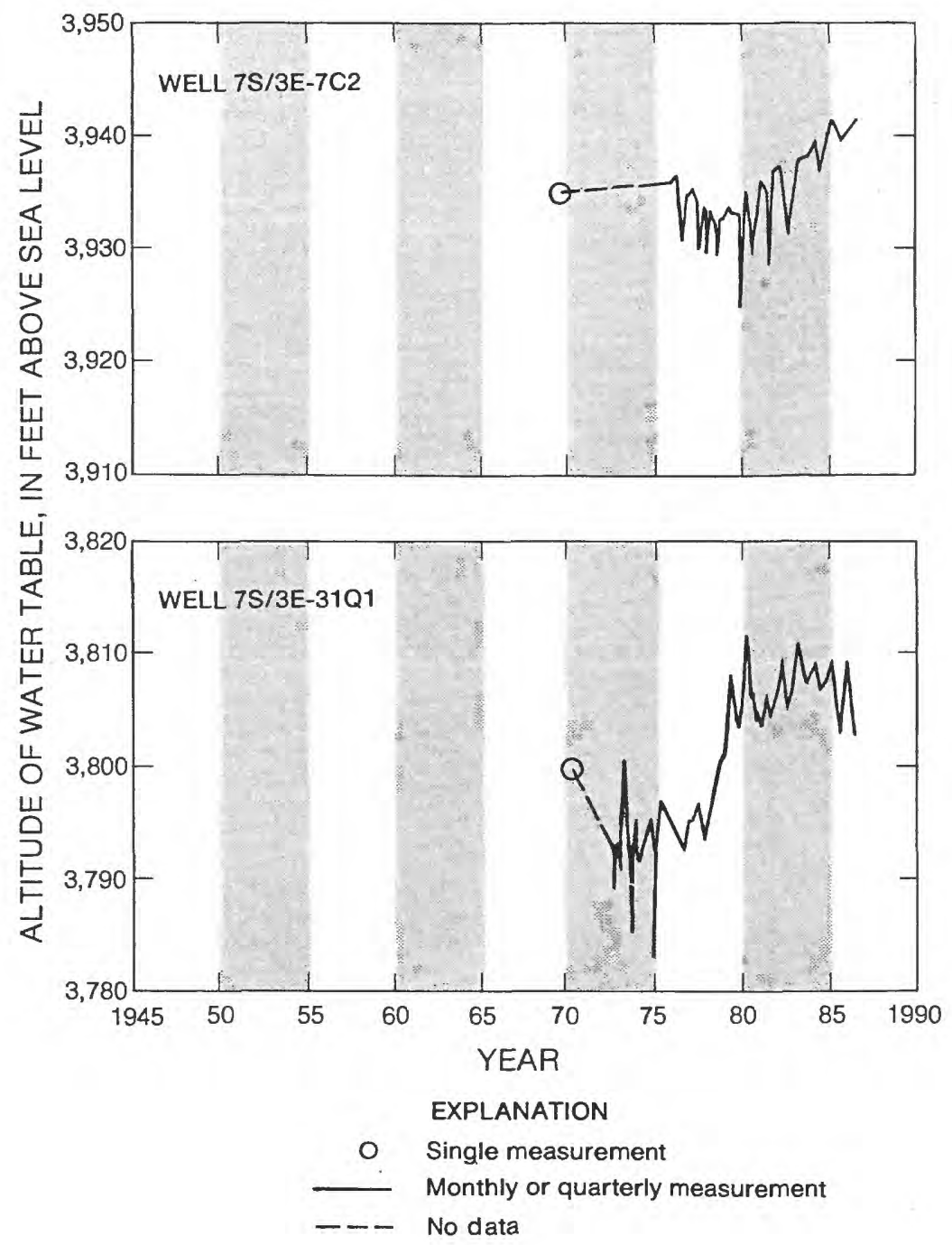

FIGURE 7.-Hydrographs showing altitude of the water table in selected wells. 

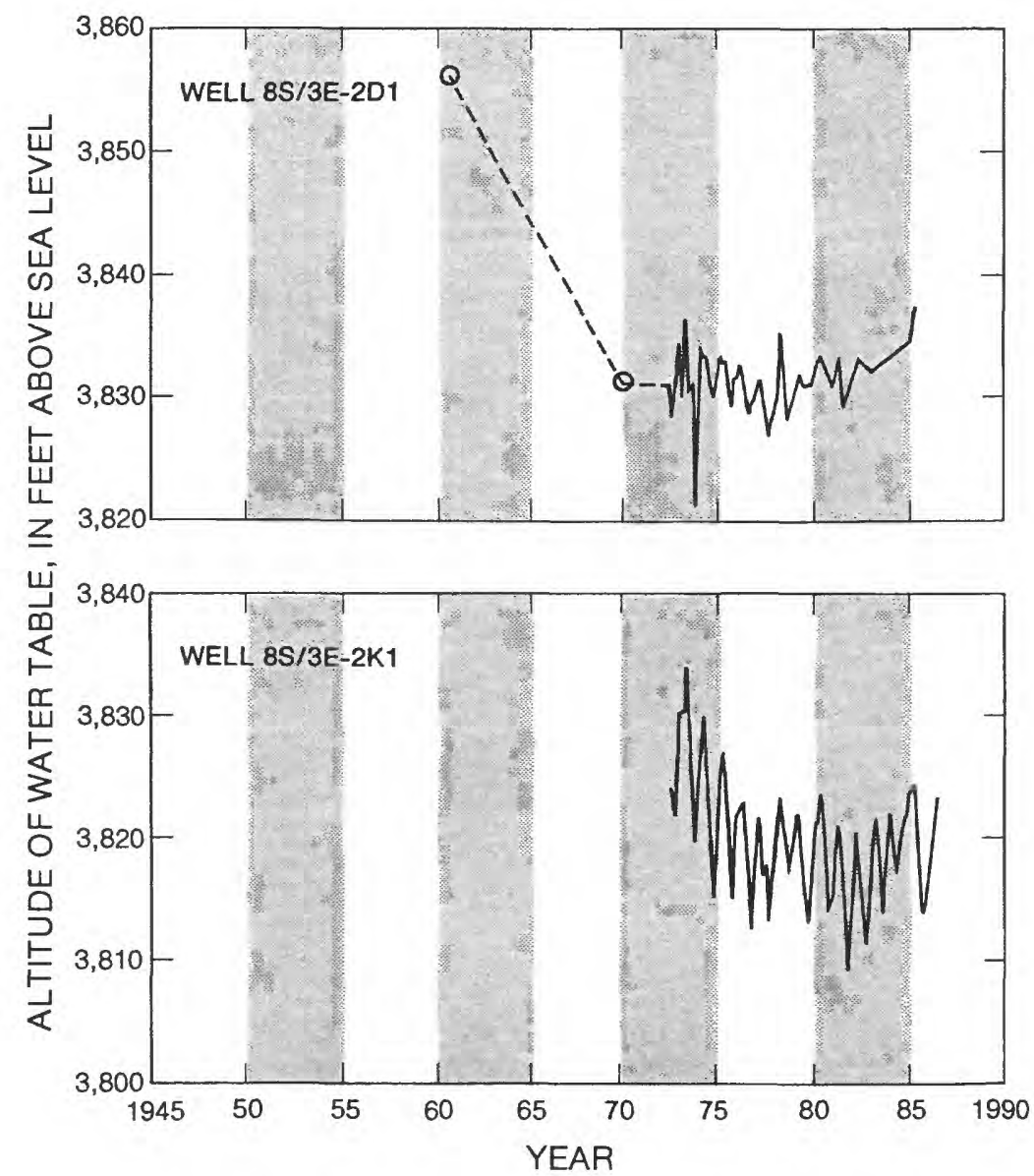

FIGURE 7. - Continued. 


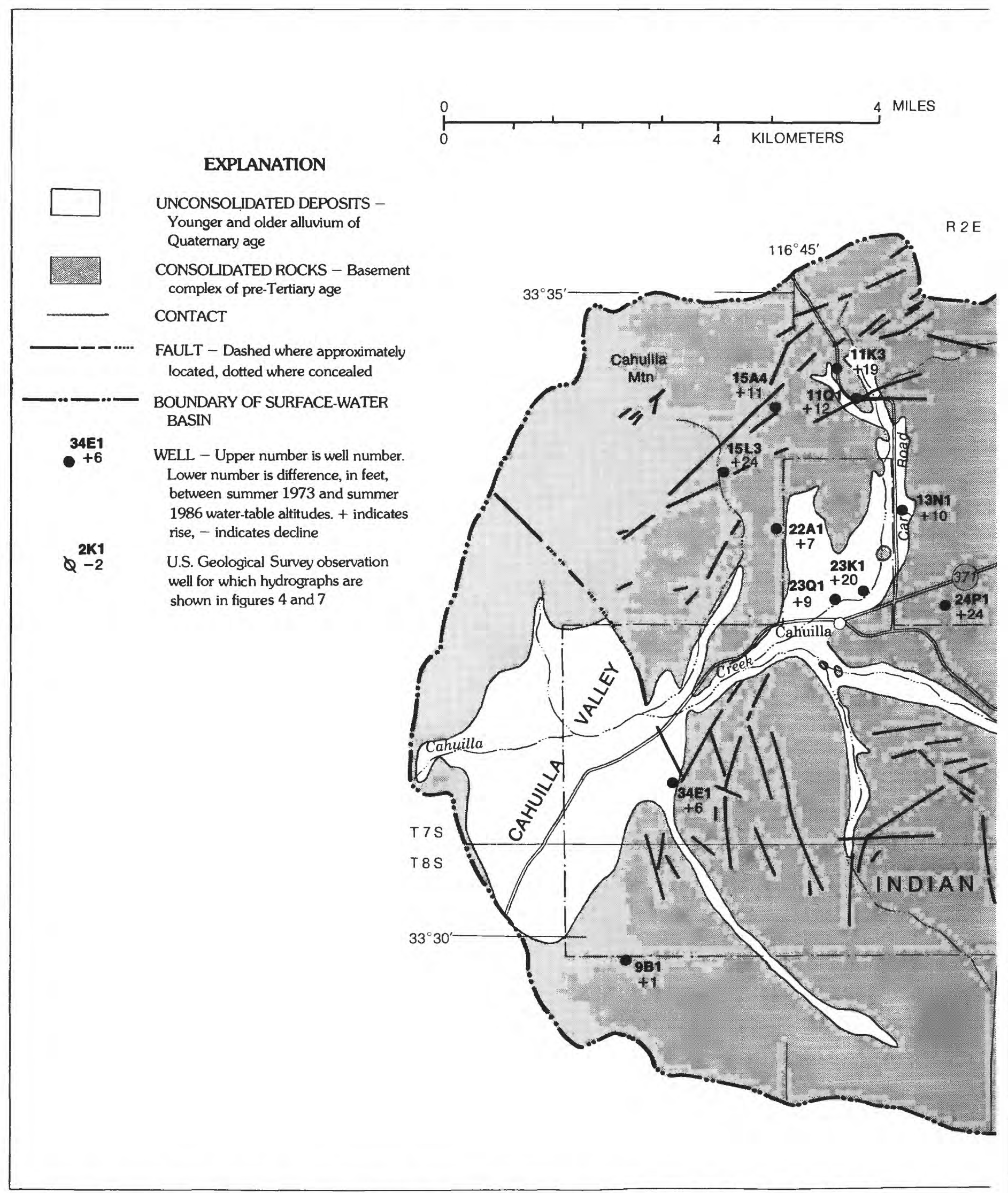

FIGURE 8.-Change in water-table altitudes between summer 1973 and summer 1986. 
Water-level measurements in 28 wells in the alluvium showed that changes in water-table altitude between the summers of 1973 and 1986 ranged from a decline of 21 feet (well 7S/3E-14P3) to a rise of 59 feet (well 8S/3E-16D1). The water table, on the average, rose 5 feet. Of the 28 wells in the alluvium, 23 were in Anza and Terwilliger Valleys where most of the pumping for irrigation occurs. Changes in water-table altitude between the summers of 1973 and 1986 in the 23 wells ranged from a decline of 21 feet (we11 7S/3E-14P3) to a rise of 39 feet (well 7S/3E-9E1). On the basis of water-level measurements in the 23 wells, the water-table rose an average of 1 foot.

Water-level measurements in 10 of 11 wells in the consolidated rocks showed higher water-table altitudes in the summer of 1986 than in the summer of 1973. Rises ranged from 1 foot (well $8 \mathrm{~S} / 2 \mathrm{E}-9 \mathrm{~B} 1$ ) to 30 feet (we11 7S/3E-7F1) in the consolidated rocks west of Anza and Terwilliger Valleys. The water table rose 31 feet in one well ( $7 \mathrm{~S} / 4 \mathrm{E}-19 \mathrm{~K} 1$ ) in the consolidated rocks east of Anza and Terwilliger Valleys. The water table in another well in the same area (7S/3E-24C1) declined 50 feet. On the basis of water-level measurements in the 11 wells, the water table rose an average of 10 feet.

There are insufficient data to accurately estimate the change in groundwater storage between the summer of 1973 and the summer of 1986. However, the average change in water-level altitude for wells measured in both years indicates that the change in storage was sma11.

WATER QUALITY

In November 1985 and January-March 1986, water from 30 wells, 5 springs, and Cahuilla Creek at three locations was sampled for chemical analyses of major anions and cations, and of nitrate. Selection of sampling sites was based on areal distribution, availability of previous water-quality records, and accessibility to sites. Chemical analyses are given in Supplemental Data C, along with water-quality records from four U.S. Geological Survey waterquality observation wells (sampled in 1984 and 1985) and wells recently drilled on Cahuilla Indian Reservation by Indian Health Services (sampled in 1984). The 1984 and 1985 chemical analyses were included to provide additional waterquality information for the study area. It is assumed that the water quality in 1986 is not significantly different from that in 1984 and 1985.

Dissolved Solids

Ground Water

We11s

Dissolved-solids and nitrate (as nitrogen) concentrations were determined for water from wells sampled for this study, from U.S. Geological Survey observation wells, and from wells drilled by the Indian Health Service. 
Dissolved-solids concentrations were estimated from specific-conductance measurements of water in wells without chemical analyses. The linear relation between dissolved-solids concentration and specific conductance serves as the basis for this technique. In general, dissolved-solids values are 0.55 to 0.75 times the value of specific conductance (Hem, 1985). Chemical analyses from this study indicate that the dissolved-solids concentration, in milligrams per liter, is approximately 0.61 times the value of specific conductance. Dissolved-solids and nitrate (as nitrogen) concentrations for 1984-86 are shown in figure 9.

Dissolved-solids concentrations in ground water ranged from 184 to 1,320 milligrams per liter $(\mathrm{mg} / \mathrm{L})$. Ground water in the eastern and central parts of Cahuilla Indian Reservation, in Lake Riverside Estates south of Highway 371, and in eastern Terwilliger Valley contained less than $500 \mathrm{mg} / \mathrm{L}$ dissolved solids. Population in these areas is sparse, and land use is limited to natural pasture, irrigated apple trees, and grain crops (fig. 2). Some wells are completed in consolidated rocks and some in unconsolidated deposits, indicating that water-quality differences (with respect to dissolved-solids concentration) between the two types of material are small.

Fourteen ground-water samples had dissolved-solids concentrations that exceeded the U.S. Environmental Protection Agency (EPA) recommended limit of $500 \mathrm{mg} / \mathrm{L}$ for drinking water (U.S. Environmental Protection Agency, 1986). In Cahuilla Valley and eastern Cahuilla Mountain, areal variation in dissolvedsolids concentration was large. Within these areas, five water samples with dissolved-solids concentrations ranging from 708 to $1,320 \mathrm{mg} / \mathrm{L}$ were collected from wells located short distances from other wells with much lower concentrations. Two of these five wells containing water with high dissolved-solids concentrations, $8 \mathrm{~S} / 2 \mathrm{E}-4 \mathrm{P} 1$ and $7 \mathrm{~S} / 2 \mathrm{E}-14 \mathrm{M1}$, are on Cahuilla Indian Reservation. Areal variation in dissolved-solids concentration within the eastern half of the study area, however, is more gradational. Water from four wells in southwestern Terwilliger Valley contained dissolved-solids concentrations ranging from 520 to $590 \mathrm{mg} / \mathrm{L}$. The remaining five samples with concentrations greater than $500 \mathrm{mg} / \mathrm{L}$ were collected from wells in Anza Valley, north of Cahuilla Indian Reservation. Dissolved-solids concentrations in these samples ranged from 570 to $810 \mathrm{mg} / \mathrm{L}$.

Most of the 14 wells that yielded water with dissolved-solids concentrations that exceed EPA limits are in areas where residential or agricultural land use predominate. High dissolved-solids concentrations are detected in ground-water samples in unsewered residential areas and usually indicate contamination from septic systems, which act as point sources of ground-water pollution (Todd and others, 1976). In addition, agricultural areas may serve as diffuse sources of high concentrations of dissolved solids through evapotranspiration; dissolution and leaching of mineral matter in the soil; and additives that are applied at land surface, such as fertilizers (Todd and others, 1976). Wells in the discharge area of a basin, such as the lower reaches of Cahuilla Creek, also may contain water with a high concentration of dissolved solids because of the increased time the water has been in contact with aquifer materials. In this case, however, evaporation from the shallow water table, often at land surface, increases the dissolved-solids concentrations in the ground water. All the above mechanisms probably contributed to the observed water-quality conditions in areas where dissolved-solids concentrations were highest. 


\section{EXPLANATION}

UNCONSOLIDATED DEPOSITS -

Younger and older alluvium of Quaternary age

CONSOLIDATED ROCKS - Basement complex of pre-Tertiary age

\section{CONTACT}

FAULT - Dashed where approximately located, dotted where concealed

SURFACE-WATER BASIN BOUNDARY SURFACE-WATER SAMPLING SITE AND NUMBER

26G51

m

SPRING AND NUMBER - Sampled for chemical analysis

34E1

Q

$23 \mathrm{H} 1$

(

32D2

$0^{6 B 1}$

$\frac{210}{0.85}$

\section{WELL AND NUMBER -}

U.S. Geological Survey water-quality observation well

Dissolved-solids concentration estimated from specific conductance

Sampled for chemical analysis

Sampled by Indian Health Services

WATER-QUALITY DATA - Upper number is dissolved solids, in milligrams per liter; lower number is nitrate (as nitrogen), in milligrams per liter. Parentheses indicate. a concentration greater than U.S. Environmental Protection Agency's recommended limit for dissolved solids, 500 milligrams per liter, and for nitrate (as nitrogen), 10 milligrams per liter

STIFF DIAGRAM FOR INDICATED SITE Differences in configuration reflect differences in chemical character. The larger

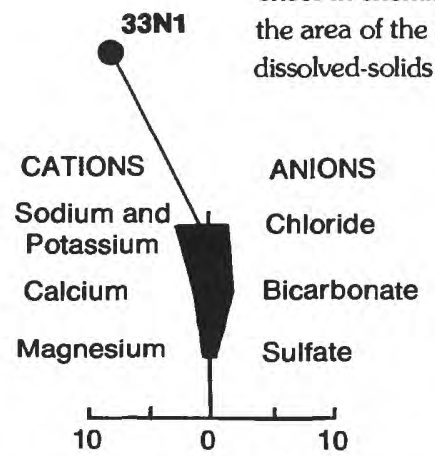

Milliequivalents per liter
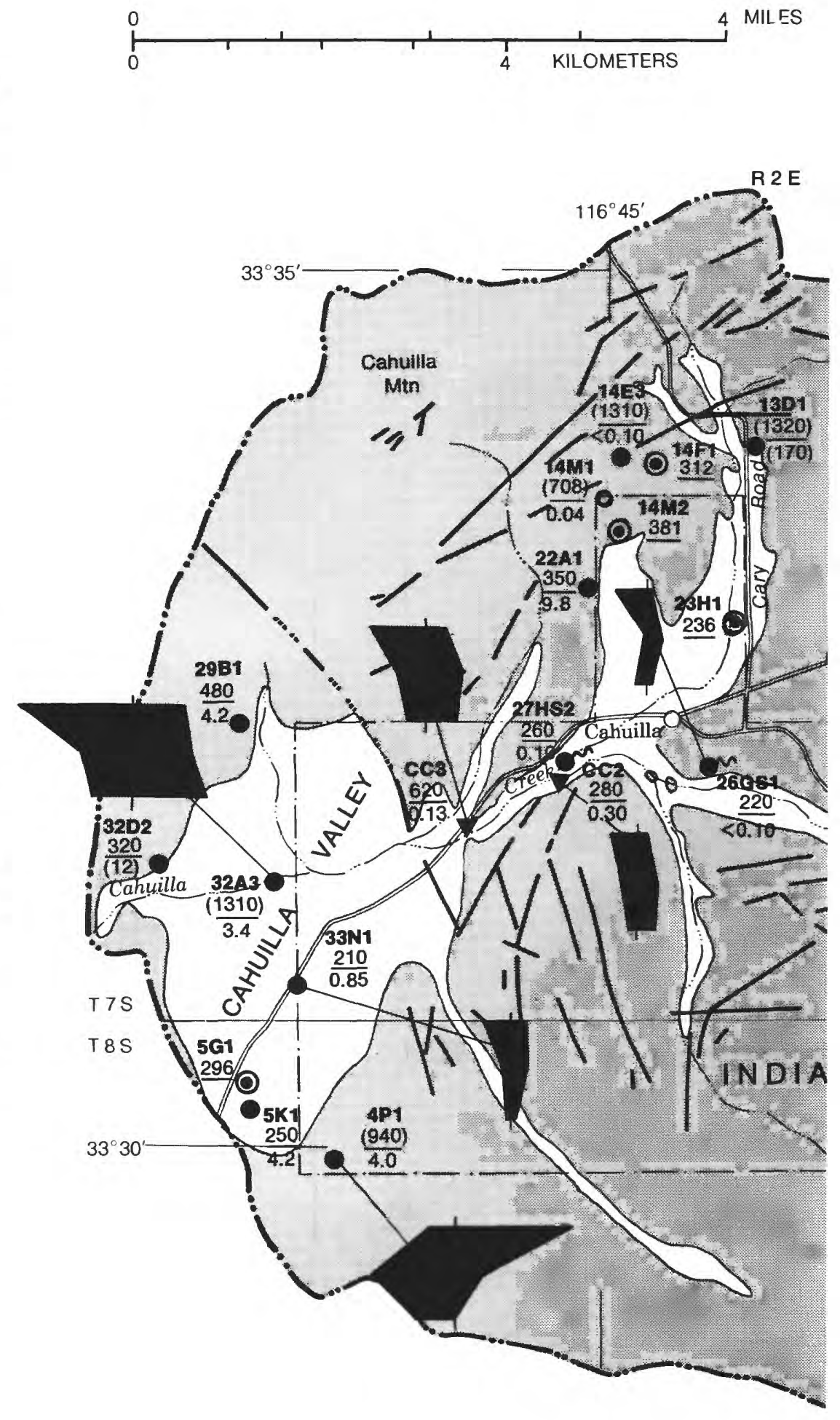

FIGURE 9.-Water quality, 1984-86. 


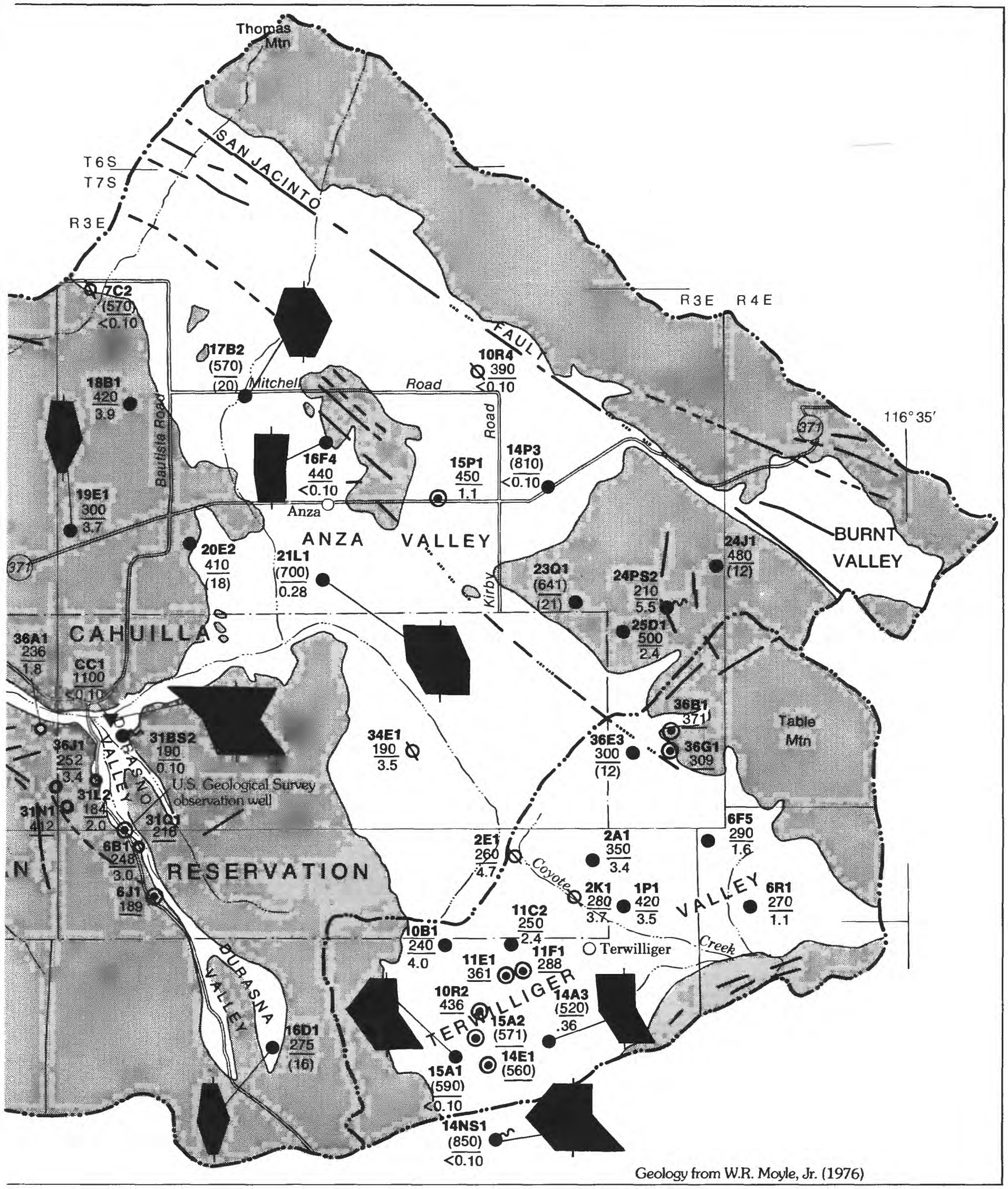


Figure 10 shows dissolved-solids concentration over a period of time for three U.S. Geological Survey water-quality observation wells in Anza Valley. Water in wells $7 \mathrm{~S} / 3 \mathrm{E}-7 \mathrm{C} 2$ and $8 \mathrm{~S} / 3 \mathrm{E}-2 \mathrm{E} 1$ had large fluctuations in dissolvedsolids concentration during 1978-81, a period of alternating high and low precipitation.

Samples from 12 wells were compared with previous water-quality records (Giessner and Mermod, 1974) to define changes in dissolved-solids concentration over time (table 4). Water from 4 of the 12 wells had increases greater than $100 \mathrm{mg} / \mathrm{L}$. Water from all wells sampled in 1984-86 that had increases are located in areas of increased agricultural development.

Most of the ground water in the study area is classified as a calcium sodium bicarbonate type, as shown by the water-quality diagrams in figure 9. Typical examples of this water type are found in wells $7 \mathrm{~S} / 3 \mathrm{E}-19 \mathrm{E} 1$ and 8S/3E-16D1. Sodium, however, occurs as the major cation in central Cahuilla Valley (wells $7 \mathrm{~S} / 2 \mathrm{E}-33 \mathrm{~N} 1$ and $7 \mathrm{~S} / 2 \mathrm{E}-32 \mathrm{~A} 3$ ). The distribution and concentration of both calcium and sodium may simply reflect the chemistry of the consolidated rocks within the study area. Tonalite, which typically contains large quantities of calcium minerals, is the predominant rock type; adamellite, which typically contains large quantities of sodium minerals, is common (Sharp, 1965). However, some occurrences of high sodium concentrations are more likely associated with the concentration of salts by evapotranspiration from irrigated fields.

Bicarbonate occurs as the major anion in most parts of the study area, especially where dissolved-solids concentrations are lower than $500 \mathrm{mg} / \mathrm{L}$. In areas where higher dissolved-solids concentrations occur, sulfate commonly is the predominant anion (for example, we11 8S/3E-15Al). Water from four of the wells sampled had sulfate concentrations that exceed the recommended limit of $250 \mathrm{mg} / \mathrm{L}$ for drinking water (U.S. Environmental Protection Agency, 1986; Supplemental Data C).

\section{Springs}

All spring samples collected throughout the study area had dissolvedsolids concentrations less than $300 \mathrm{mg} / \mathrm{L}$, except for spring $8 \mathrm{~S} / 3 \mathrm{E}-14 \mathrm{NSl}$, which contained water with a dissolved-solids concentration of $850 \mathrm{mg} / \mathrm{L}$. Water from spring $8 \mathrm{~S} / 3 \mathrm{E}-14 \mathrm{NSl}$ had a sulfate concentration of $390 \mathrm{mg} / \mathrm{L}$, which exceeds the EPA recommended limit for drinking water. Spring $8 \mathrm{~S} / 3 \mathrm{E}-14 \mathrm{NS} 1$ also is the only sampled spring in which the concentration of dissolved solids in the water exceeded the concentrations in water from nearby wells. The closest sampled well (8S/3E-15Al) to this spring contained water with a similar calcium sulfate type (fig. 9), indicating that the sulfate may be naturally occurring rather than from a point source of contamination such as a septic system. Sodium also occurs naturally in high concentrations, as shown by water from spring $7 \mathrm{~S} / 2 \mathrm{E}-26 \mathrm{GS} 1$, which was a sodium bicarbonate type. Water from the remaining sampled springs is classified as a calcium sodium bicarbonate type. 
Table 4.--Comparison of historical and 1984-86 dissolved-solids concentrations in water from selected wells

[Concentrations are given in milligrams per liter. Month and year we11 was sampled is in parentheses]

\begin{tabular}{lcr}
\hline $\begin{array}{c}\text { We11 } \\
\text { No. }\end{array}$ & $\begin{array}{c}\text { Historical } \\
\text { dissolved-solids } \\
\text { concentration }\end{array}$ & $\begin{array}{c}1984-86 \\
\text { dissolved-solids } \\
\text { concentration }\end{array}$ \\
\hline 7S/2E-13D1 & 415 (Dec. 1964) & 1,320 (Jan. 1986) \\
7S/2E-14E3 & 1,040 (June 1970) & 1,310 (Jan. 1986) \\
7S/3E-7C2 & 570 (May 1976) & 570 (July 1985) \\
7S/3E-15P1 & 405 (Nov. 1962) & 450 (Jan. 1986) \\
7S/3E-17B2 & 490 (Oct. 1962) & 570 (Jan. 1986) \\
7S/3E-20E2 & 310 (Oct. 1962) & 410 (Jan. 1986) \\
7S/3E-21L1 & 445 (May 1953) & 700 (Jan. 1986) \\
7S/3E-23Q1 & 600 (Nov. 1962) & 184 (Feb. 1984) \\
7S/3E-31L2 & 179 (June 1970) & 190 (Aug. 1985) \\
7S/3E-34E1 & 186 (July 1976) & 260 (Aug. 1984) \\
8S/3E-2E1 & 286 (May 1976) & 280 (Aug. 1985) \\
8S/3E-2K1 & 339 (Sept. 1977) & \\
\hline
\end{tabular}

Surface Water

Water samples collected from Cahuilla Creek in March 1986 had dissolved-solids concentrations of $1,100 \mathrm{mg} / \mathrm{L}$ upstream at site CC1, $280 \mathrm{mg} / \mathrm{L}$ at site CC2, and $620 \mathrm{mg} / \mathrm{L}$ at site CC3 farthest downstream (fig. 9). All three sites along Cahuilla Creek were sampled, at the same time, during a period of above-average discharge.

Distribution of dissolved-solids concentrations in water at the three sampling sites along Cahuilla Creek suggests that the high dissolved-solids concentrations in water at the upstream reaches of Cahuilla Creek most likely were a result of irrigation runoff and soil-zone leaching. Site CCl is approximately 2 miles downstream from the main agricultural areas in the study area. Improved surface-water quality at the central sampling site CC2 probab1y was the result of natural ground-water discharge from Durasno Valley. Ground water in Durasno Valley generally contained less than $300 \mathrm{mg} / \mathrm{L}$ dissolved solids. A change from sulfate as the predominant anion upstream at site CCl to bicarbonate as the predominant anion at site $\mathrm{CC} 2$ also indicates a downstream dilution by ground water. Increased dissolved-solids concentration in water at site CC3 probably was due to the introduction of water with a high dissolvedsolids concentration from a tributary that drains the eastern Cahuilla Mountain area. Ground water from wells located along this tributary contained dissolved-solids concentrations generally ranging from 200 to $1,300 \mathrm{mg} / \mathrm{L}$. 


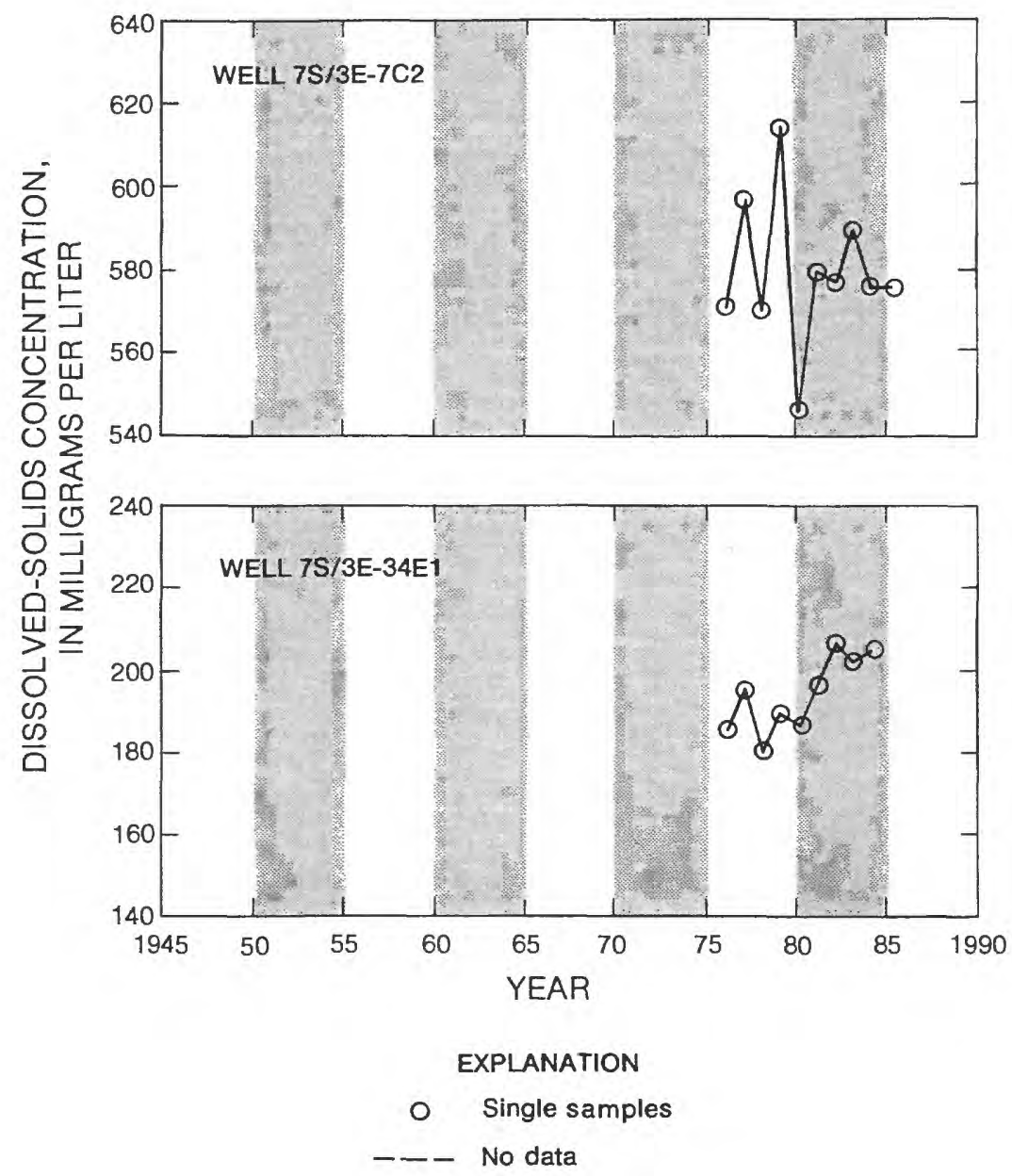

FIGURE 10.-Dissolved-solids concentration in water from selected wells. 


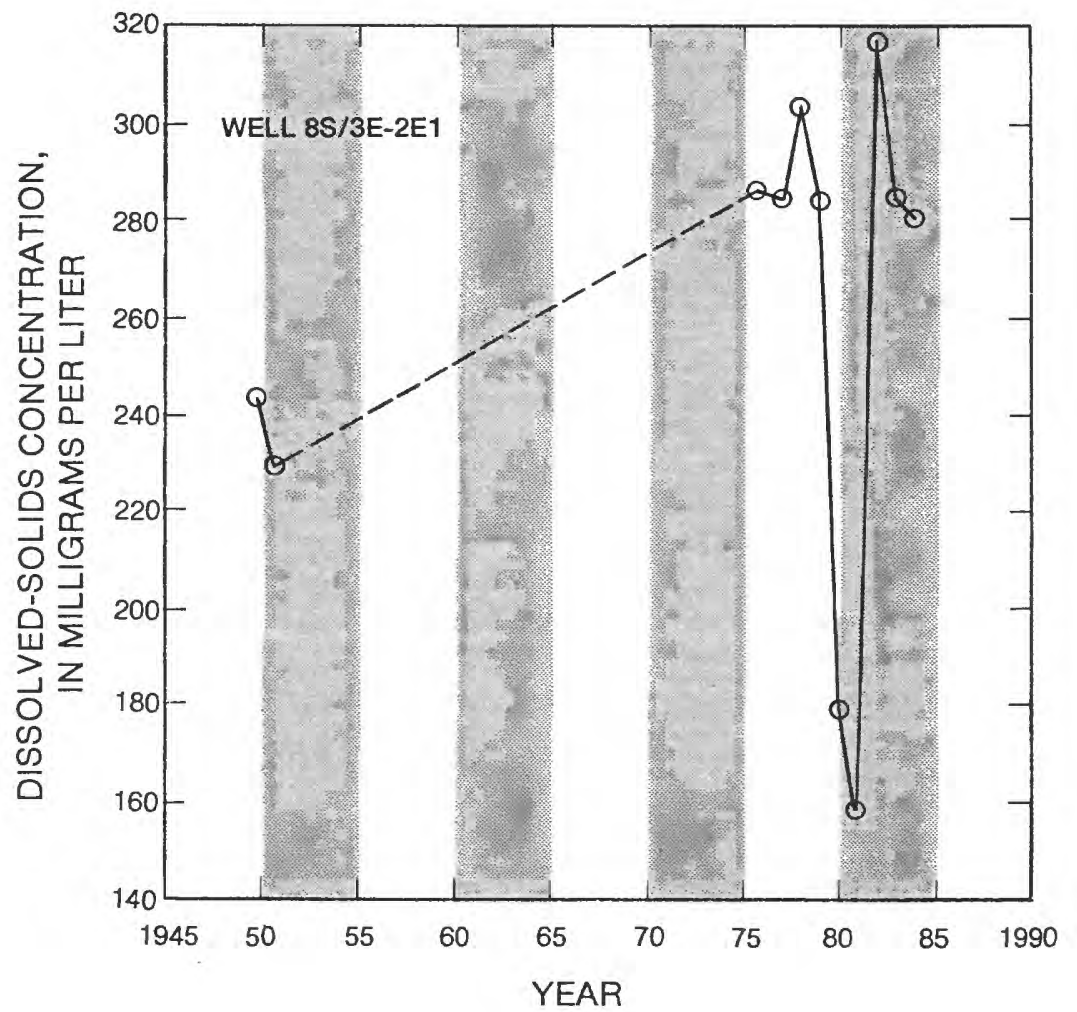

FIGURE 10.- Continued. 


\section{Nitrate}

Nitrate (as nitrogen) concentration in ground water exceeded the EPA drinking-water limit of $10 \mathrm{mg} / \mathrm{L}$ (U.S. Environmental Protection Agency, 1986) in eight of the wells sampled in 1986 (fig. 9). Nitrate concentrations in the eight samples ranged from 12 to $170 \mathrm{mg} / \mathrm{L}$ (Supplemental Data C). Most sampled wells containing water with high nitrate concentrations were perforated in weathered consolidated rocks. Water levels in these wells ranged from 13.4 to 78.5 feet below land surface.

Animal wastes and septic systems appear to be the main sources of nitrate in these areas. Most of the eight wells that yielded water with nitrate concentrations exceeding the EPA recommended limit are in residential areas where agricultural land use is low. Three wells, however, are on sites of previously active commercial animal farms (7S/2E-13D1 and 7S/3E-20E2) or within unirrigated pasture used for grazing cattle (8S/3E-16D1). Diffuse sources of nitrate include the application of nitrogen fertilizers, animal waste, and leachate from waste-disposal areas (U.S. Environmental Protection Agency, 1986). However, concentrations of nitrate (as nitrogen) were less than $10 \mathrm{mg} / \mathrm{L}$ in all water samples collected from wells in the main agricultural areas in Anza and Terwilliger Valleys, except for one sample. High nitrate concentrations as a result of nitrogen fertilizers are therefore thought to be minimal. Nitrate (as nitrogen) concentrations in all water samples collected on Cahuilla Indian Reservation were less than the EPA drinking-water limit.

\section{EVALUATION OF THE OBSERVATION-WELL NETWORK}

The existing observation-well network (fig. 3) has been operational since 1973. Currently (1986), water levels are measured quarterly in six wells $(7 \mathrm{~S} / 3 \mathrm{E}-7 \mathrm{C} 2$, 7S/3E-14P3, 7S/3E-31Q1, 7S/3E-34E $1,8 \mathrm{~S} / 3 \mathrm{E}-2 \mathrm{D} 1$, and $8 \mathrm{~S} / 3 \mathrm{E}-2 \mathrm{~K} 1)$, and water is sampled annually from five wells (7S/3E-7C2, 7S/3E-10R4, 7S/3E-34E 1 , $8 \mathrm{~S} / 3 \mathrm{E}-2 \mathrm{E} 1$, and $8 \mathrm{~S} / 3 \mathrm{E}-2 \mathrm{~K} 1$ ) for chemical analyses. All the wells are in the eastern part of the study area where agricultural development is most intense, except 7S/3E-31Q1, which is in Durasno Valley.

Hydrographs in figures 4 and 7 indicate that water levels in wells included in the existing network adequately reflect long-term water-level changes in agricultural areas. Current distribution of observation wells and the frequency of measurement are adequate most of the year, when ground-water flow is toward the streams. However, locally there is a depletion of groundwater storage during the summer heavy pumping season. Additional observation wells in Anza Valley near the reservation, where several irrigation wells are located, would allow monitoring of the effects of increased pumping during summer. Existing wells north of the reservation boundary in township 7S, range $3 E$, sections 21 or 22 , could be used to supplement the present observation-we11 network. Monthly measurements of water levels in all observation wells during the summer would improve definition of the extent of water-level declines. 
Distribution of wells in the existing water-quality observation-well network adequately reflects current water-quality conditions in the eastern part of the study area. Because recharge to the ground-water system was above normal during 1976-86, increases in concentrations of dissolved solids and nitrate have been minimized as a result of greater dilution.

Expansion of the water-quality observation-well network to include two other parts of the study area, however, would be desirable. The first area is in Durasno Valley. Water from well 8S/3E-16Dl, upgradient from Durasno Valley, had a nitrate (as nitrogen) concentration of $16 \mathrm{mg} / \mathrm{L}$ when sampled in 1986. This is greater than the EPA recommended limit for drinking water. The second area is in the northernmost part of the reservation, north of the town of Cahuilla. Two wells north of this part of the reservation, and one on the reservation, yielded water with dissolved-solids concentrations greater than $500 \mathrm{mg} / \mathrm{L}$ when sampled in 1986. In addition, water from one of the wells north of the reservation had a high $(170 \mathrm{mg} / \mathrm{L})$ nitrate concentration.

\section{SUMMARY AND CONCLUSIONS}

Principal ground-water uses in the Anza-Terwilliger area during 1986 were irrigation of crops, evapotranspiration from natural pasture, domestic supplies, livestock supplies, pumpage for maintenance of lakes and reservoirs, and evaporation in areas where the water table was at land surface. Consumptive use of ground water is estimated at 10,000 acre-ft during 1986, an increase of 6,000 acre-ft from 1973. The increase in agricultural activities accounts for almost half of the additional consumptive use since 1973. The remaining increase is due mainly to the increased amounts of ground water evaporated in high-water-table areas.

Ground water in the study area is derived entirely from precipitation. Precipitation data for 1943-86 indicate that 1943-75 was a relatively dry period. Water-level measurements for 1943-75 indicate that ground-water discharge exceeded recharge and the water table generally declined. During 1976-86, wet conditions prevailed, and the water table rose in most areas, including the Cahuilla Indian Reservation.

Prior to 1950 , movement of ground water was toward Cahuilla and Coyote Creeks. During 1986, ground water generally moved in the same direction, but ground water also moved toward two areas of ground-water withdrawal created by heavy summer pumping for irrigation. One area, in central Anza Valley, extended to the northern boundary of the reservation; the other was in northeastern Anza Valley northeast of the reservation.

Dissolved-solids concentrations in ground water during 1984-86 ranged from 184 to $1,320 \mathrm{mg} / \mathrm{L}$ within the study area. Water from 14 of the we11s had dissolved-solids concentrations greater than the EPA recommended limit for drinking water of $500 \mathrm{mg} / \mathrm{L}$. The high dissolved-solids concentrations in ground water were in residential and agricultural areas. 
Calcium was the predominant dissolved cation in ground water in most parts of the study area. Bicarbonate was the predominant dissolved anion in areas where dissolved-solids concentrations were less that $500 \mathrm{mg} / \mathrm{L}$. Where dissolved-solids concentrations were greater than $500 \mathrm{mg} / \mathrm{L}$, sulfate commonly was the predominant anion. Sulfate concentration exceeded the EPA recommended drinking-water 1 imit of $250 \mathrm{mg} / \mathrm{L}$ in water from four wells.

All water samples collected from springs had dissolved-solids concentrations less than $300 \mathrm{mg} / \mathrm{L}$, except for a concentration of $850 \mathrm{mg} / \mathrm{L}$ in water from one spring. Water from most springs that were sampled can be classified as calcium sodium bicarbonate type.

Water samples collected from Cahuilla Creek in 1986 had dissolved-solids concentrations that ranged from 280 to $1,100 \mathrm{mg} / \mathrm{L}$. Sodium and sulfate were the predominant dissolved ions in water from upstream reaches of the creek, but bicarbonate significantly increased in concentration farther downstream.

Nitrate (as nitrogen) concentration in ground water ranged from 0.0 to 170 $\mathrm{mg} / \mathrm{L}$. Water from eight of the sampling locations had concentrations higher than the EPA recommended limit for drinking water of $10 \mathrm{mg} / \mathrm{L}$. High nitrate concentrations were detected in samples throughout the study area, but most high concentrations were in water from wells completed in weathered consolidated rocks. Concentrations generally were less than $10 \mathrm{mg} / \mathrm{L}$ in the agricultural areas of Anza and Terwilliger Valleys, indicating that effects from nitrogen fertilizers were minimal. Nitrate (as nitrogen) concentrations in water from all sampling locations on Cahuilla Indian Reservation were less than the EPA drinking-water limit.

The observation-we11 network was found to be generally adequate for detecting changes in water level and water quality. However, the addition of observation wells in Anza Valley near the reservation would allow monitoring of water levels during the summer heavy pumping season. Also, additional observation wells downgradient from an area of high nitrate concentrations in Durasna Valley and in an area of high dissolved-solids concentrations north of the town of Cahuilla would be desirable. 
Giessner, F.W. and Mermod, M.J., 1974, Water wells and springs in the eastern part of the Upper Santa Margarita River watershed, Riverside and San Diego Counties, California: California Department of Water Resources Bulletin 91-22, $213 \mathrm{p}$.

Hem, J.D., 1985, Study and interpretation of the chemical characteristics of natural water: U.S. Geological Survey Water-Supply Paper 2254, 263 p.

Krieger and Stewart Engineering Consultants, 1986, Preliminary evaluation of groundwater pumping of AWD [Anza Water District] wells within the Anza-Terwilliger groundwater basin: Krieger and Stewart Engineering Consultants, Riverside, California, 16 p.

Moyle, W.R., Jr., 1976, Geohydrology of the Anza-Terwilliger area, Riverside County, California: U.S. Geological Survey Water-Resources Investigations $76-10,25 \mathrm{p}$.

Sharp, R.V., 1965, Geology of the San Jacinto fault zone in the Peninsular Ranges of southern California: Pasadena, California, California Institute of Technology, Ph.D. dissertation, $184 \mathrm{p}$.

Todd, D.K., Tinlin, R.M., Schmidt, K.D., and Everett, L.D., 1976, Monitoring groundwater quality: Monitoring methodology: U.S. Environmental Protection Agency-600/4-76-026, 154 p.

U.S. Environmental Protection Agency, 1986, Quality criteria for water: Washington, D.C., U.S. Government Printing Office, EPA 440/5-86-001. 
SUPPLEMENTAL DATA
A: Well Construction
B: Water Levels
C: Water Quality 


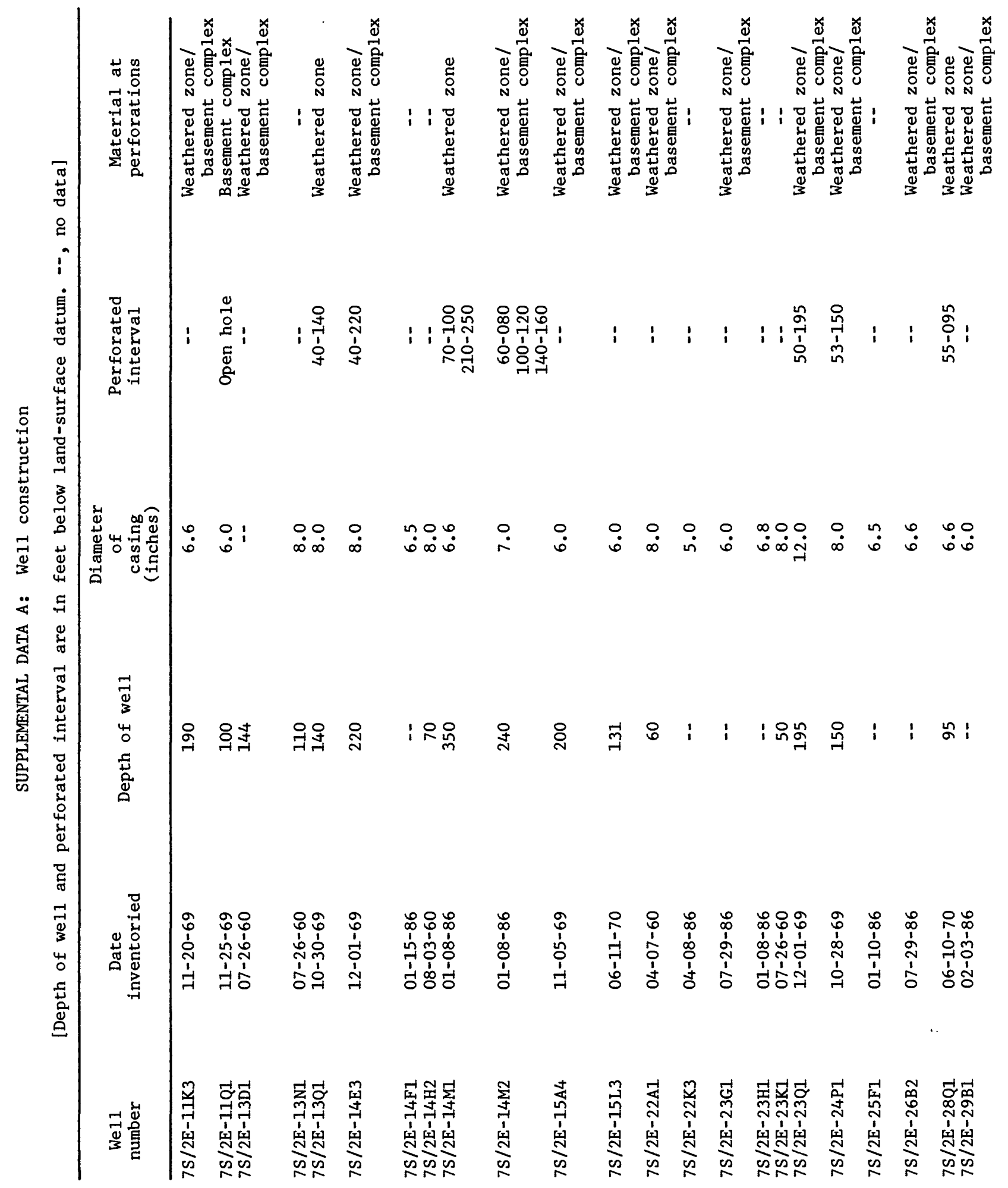




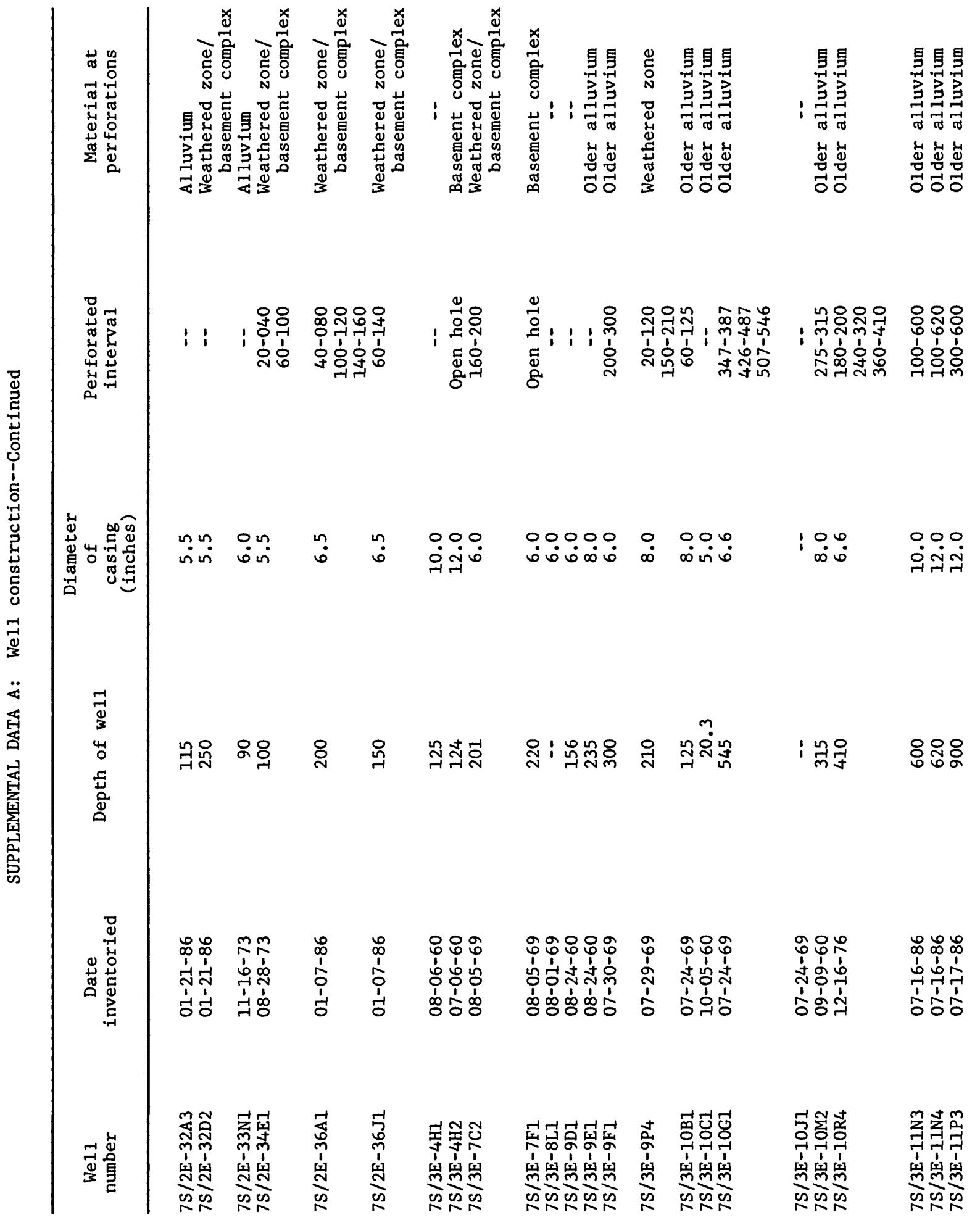




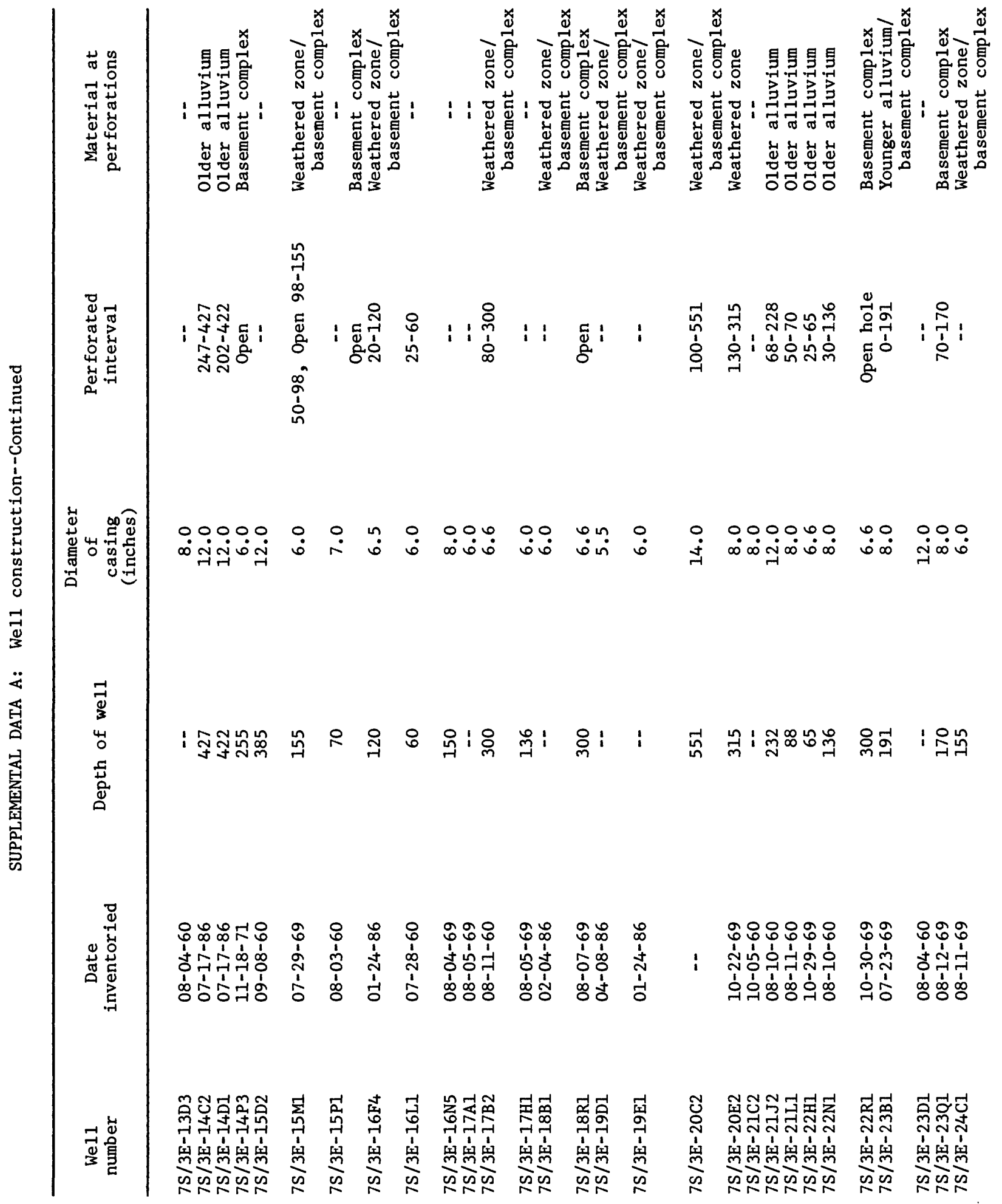




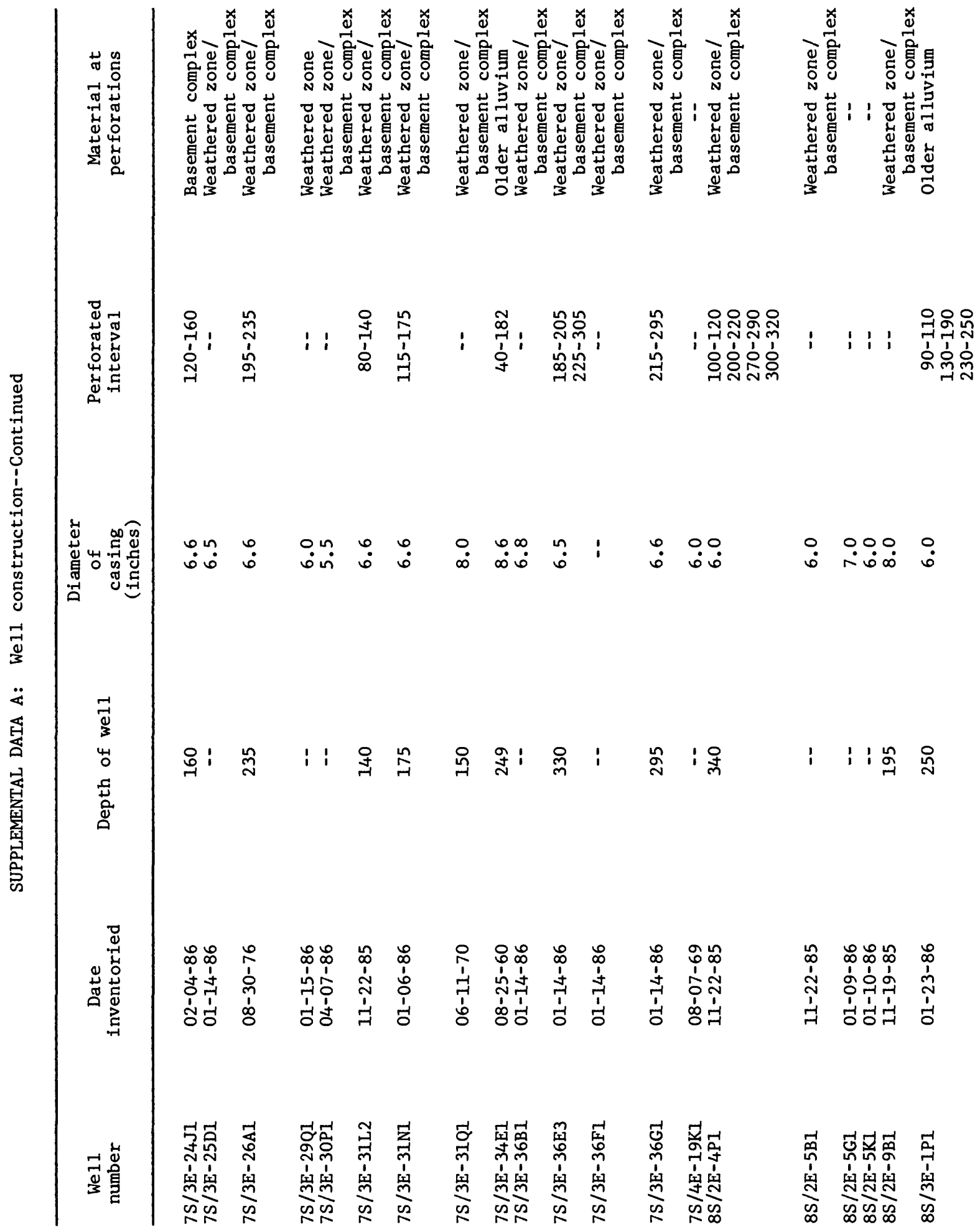




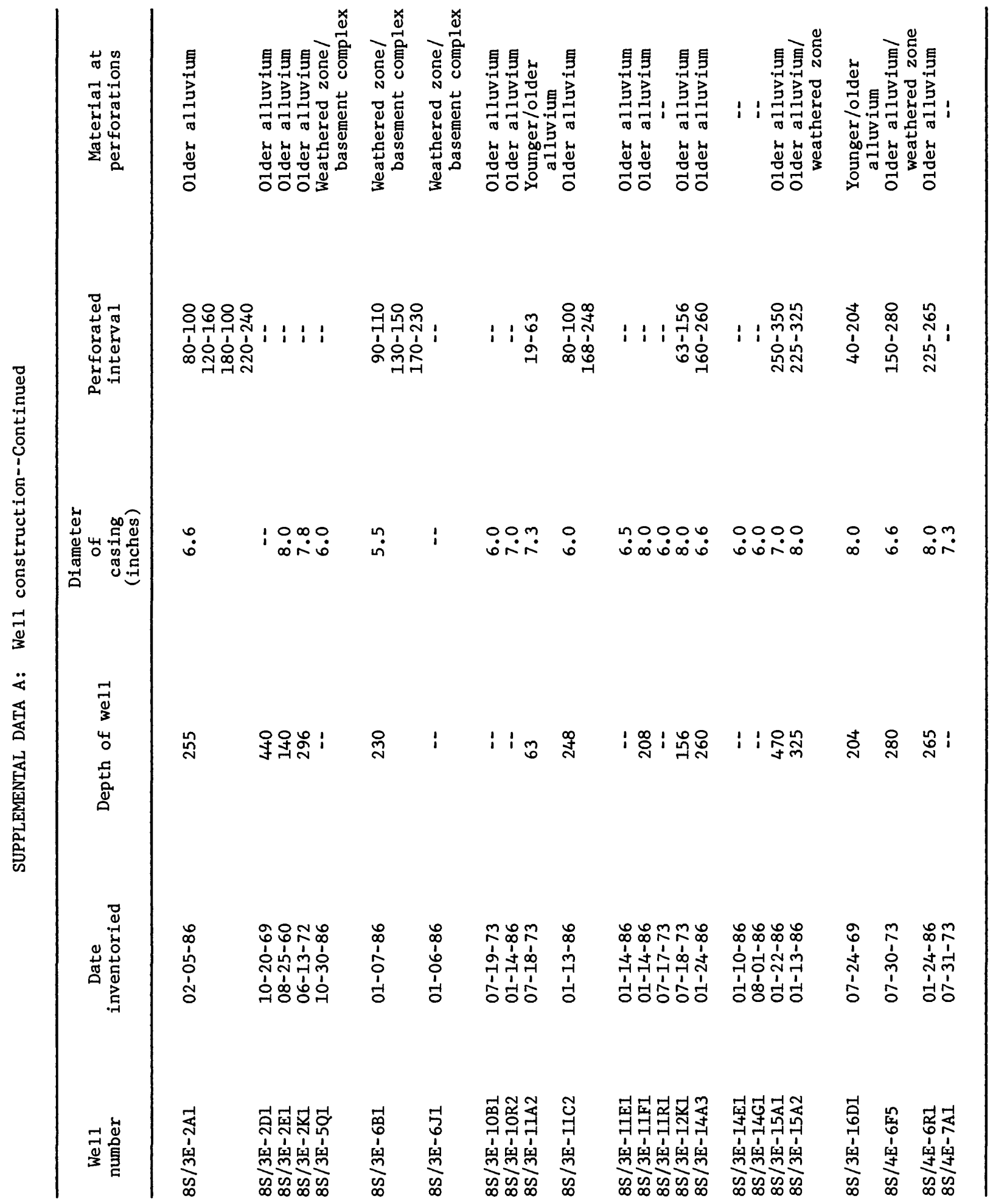


SUPPLEMENTAL DATA B: Water levels

[Altitude, in feet, refers to distance above sea level. Site status: $p$, pumping; $r$, recently pumped; $s$, static]

\begin{tabular}{|c|c|c|c|c|c|}
\hline $\begin{array}{l}\text { We11 } \\
\text { number }\end{array}$ & $\begin{array}{c}\text { Measurement } \\
\text { date }\end{array}$ & $\begin{array}{l}\text { Land- } \\
\text { surface } \\
\text { altitude } \\
\text { (feet) }\end{array}$ & $\begin{array}{c}\text { Depth } \\
\text { to water } \\
\text { (feet below } \\
\text { land surface) }\end{array}$ & $\begin{array}{l}\text { Water- } \\
\text { table } \\
\text { altitude } \\
\text { (feet) }\end{array}$ & $\begin{array}{l}\text { Site } \\
\text { status }\end{array}$ \\
\hline $7 \mathrm{~S} / 2 \mathrm{E}-11 \mathrm{~K} 3$ & $\begin{array}{l}11-20-69 \\
08-22-73 \\
08-01-86\end{array}$ & 3,860 & $\begin{array}{l}62.40 \\
62.93 \\
43.59\end{array}$ & $\begin{array}{l}3,798 \\
3,797 \\
3,816\end{array}$ & $\begin{array}{l}\mathrm{s} \\
\mathrm{s} \\
\mathrm{s}\end{array}$ \\
\hline $7 \mathrm{~S} / 2 \mathrm{E}-11 \mathrm{Q} 1$ & $\begin{array}{l}11-25-69 \\
08-22-73 \\
08-01-86\end{array}$ & 3,800 & $\begin{array}{l}27.42 \\
30.93 \\
18.58\end{array}$ & $\begin{array}{l}3,773 \\
3,769 \\
3,781\end{array}$ & $\begin{array}{l}\mathrm{s} \\
\mathrm{s} \\
\mathrm{s}\end{array}$ \\
\hline $7 \mathrm{~S} / 2 \mathrm{E}-13 \mathrm{D} 1$ & $\begin{array}{l}11-29-51 \\
11-21-52 \\
05-07-53 \\
11-09-53\end{array}$ & 3,772 & $\begin{array}{l}40.20 \\
21.10 \\
22.00 \\
24.90\end{array}$ & $\begin{array}{l}3,732 \\
3,751 \\
3,750 \\
3,747\end{array}$ & $\begin{array}{l}\mathrm{s} \\
\mathrm{s} \\
\mathrm{s} \\
\mathrm{s}\end{array}$ \\
\hline & $\begin{array}{l}05-10-54 \\
07-26-60 \\
10-31-69 \\
04-08-86 \\
07-29-86\end{array}$ & & $\begin{array}{l}31.80 \\
32.42 \\
35.40 \\
20.32 \\
19.65\end{array}$ & $\begin{array}{l}3,740 \\
3,740 \\
3,737 \\
3,752 \\
3,752\end{array}$ & $\begin{array}{l}\mathrm{s} \\
\mathrm{s} \\
\mathrm{s} \\
\mathrm{s} \\
\mathrm{s}\end{array}$ \\
\hline $7 \mathrm{~S} / 2 \mathrm{E}-13 \mathrm{~N} 1$ & $\begin{array}{l}11-29-51 \\
11-21-52 \\
05-07-53 \\
11-10-53 \\
05-10-54\end{array}$ & 3,700 & $\begin{array}{l}50.10 \\
40.10 \\
39.10 \\
42.30 \\
42.80\end{array}$ & $\begin{array}{l}3,650 \\
3,660 \\
3,661 \\
3,658 \\
3,657\end{array}$ & $\begin{array}{l}\mathrm{s} \\
\mathrm{s} \\
\mathrm{s} \\
\mathrm{s} \\
\mathrm{s}\end{array}$ \\
\hline & $\begin{array}{l}07-26-60 \\
10-30-69 \\
08-22-73 \\
07-31-86\end{array}$ & & $\begin{array}{l}53.93 \\
40.55 \\
38.94 \\
29.04\end{array}$ & $\begin{array}{l}3,646 \\
3,659 \\
3,661 \\
3,671\end{array}$ & $\begin{array}{l}\mathrm{s} \\
\mathrm{s} \\
\mathrm{s} \\
\mathrm{s}\end{array}$ \\
\hline $7 \mathrm{~S} / 2 \mathrm{E}-13 \mathrm{Q} 1$ & $07-31-86$ & 3,770 & 29.02 & 3,741 & s \\
\hline $7 \mathrm{~S} / 2 \mathrm{E}-14 \mathrm{E} 3$ & $\begin{array}{l}12-01-69 \\
06-11-70 \\
07-29-86\end{array}$ & 3,760 & $\begin{array}{l}38.10 \\
47.22 \\
24.24\end{array}$ & $\begin{array}{l}3,722 \\
3,713 \\
3,736\end{array}$ & $\begin{array}{l}\mathrm{s} \\
\mathrm{s} \\
\mathrm{s}\end{array}$ \\
\hline $7 \mathrm{~S} / 2 \mathrm{E}-14 \mathrm{~F} 1$ & $\begin{array}{l}01-15-86 \\
07-16-86\end{array}$ & 3,762 & $\begin{array}{l}51.59 \\
49.67\end{array}$ & $\begin{array}{l}3,710 \\
3,712\end{array}$ & $\begin{array}{l}\mathrm{s} \\
\mathrm{s}\end{array}$ \\
\hline
\end{tabular}


SUPPLEMENTAL DATA B: Water levels--Continued

\begin{tabular}{|c|c|c|c|c|c|}
\hline $\begin{array}{l}\text { We11 } \\
\text { number }\end{array}$ & $\begin{array}{l}\text { Measurement } \\
\text { date }\end{array}$ & $\begin{array}{l}\text { Land- } \\
\text { surface } \\
\text { altitude } \\
\text { (feet) }\end{array}$ & $\begin{array}{c}\text { Depth } \\
\text { to water } \\
\text { (feet below } \\
\text { land surface) }\end{array}$ & $\begin{array}{l}\text { Water- } \\
\text { table } \\
\text { altitude } \\
\text { (feet) }\end{array}$ & $\begin{array}{l}\text { Site } \\
\text { status }\end{array}$ \\
\hline $7 \mathrm{~S} / 2 \mathrm{E}-14 \mathrm{H} 2$ & $\begin{array}{l}11-10-53 \\
05-10-54 \\
08-03-60 \\
11-25-69 \\
07-31-86\end{array}$ & 3,730 & $\begin{array}{l}33.70 \\
30.80 \\
36.21 \\
28.20 \\
27.39\end{array}$ & $\begin{array}{l}3,696 \\
3,699 \\
3,694 \\
3,702 \\
3,703\end{array}$ & $\begin{array}{l}\mathrm{s} \\
\mathrm{s} \\
\mathrm{s} \\
\mathrm{s} \\
\mathrm{s}\end{array}$ \\
\hline $7 \mathrm{~S} / 2 \mathrm{E}-14 \mathrm{Ml}$ & $\begin{array}{l}01-08-86 \\
04-07-86 \\
07-17-86\end{array}$ & 3,700 & $\begin{array}{r}10.79 \\
6.40 \\
10.60\end{array}$ & $\begin{array}{l}3,689 \\
3,694 \\
3,689\end{array}$ & $\begin{array}{l}\mathrm{s} \\
\mathrm{s} \\
\mathrm{s}\end{array}$ \\
\hline $7 \mathrm{~S} / 2 \mathrm{E}-14 \mathrm{M} 2$ & $\begin{array}{l}01-08-86 \\
04-07-86 \\
07-17-86\end{array}$ & 3,690 & $\begin{array}{l}23.55 \\
19.50 \\
20.44\end{array}$ & $\begin{array}{l}3,666 \\
3,670 \\
3,670\end{array}$ & $\begin{array}{l}\mathrm{r} \\
\mathrm{s} \\
\mathrm{s}\end{array}$ \\
\hline $7 \mathrm{~S} / 2 \mathrm{E}-15 \mathrm{~A} 4$ & $\begin{array}{l}11-05-69 \\
08-22-73 \\
08-01-86\end{array}$ & 3,830 & $\begin{array}{l}35.07 \\
38.98 \\
28.38\end{array}$ & $\begin{array}{l}3,795 \\
3,791 \\
3,802\end{array}$ & $\begin{array}{l}\mathbf{s} \\
\mathbf{s} \\
\mathbf{s}\end{array}$ \\
\hline $7 \mathrm{~S} / 2 \mathrm{E}-15 \mathrm{~L} 3$ & $\begin{array}{l}08-23-73 \\
08-01-86\end{array}$ & 3,820 & $\begin{array}{r}32.72 \\
9.38\end{array}$ & $\begin{array}{l}3,787 \\
3,811\end{array}$ & $\begin{array}{l}\mathrm{s} \\
\mathrm{s}\end{array}$ \\
\hline $7 \mathrm{~S} / 2 \mathrm{E}-22 \mathrm{Al}$ & $\begin{array}{l}04-07-53 \\
11-09-53 \\
05-10-54 \\
09-08-60\end{array}$ & 3,670 & $\begin{array}{l}23.50 \\
32.00 \\
27.90 \\
28.55\end{array}$ & $\begin{array}{l}3,646 \\
3,638 \\
3,642 \\
3,641\end{array}$ & $\begin{array}{l}\mathrm{s} \\
\mathrm{s} \\
\mathrm{s} \\
\mathrm{s}\end{array}$ \\
\hline & $\begin{array}{l}10-23-69 \\
08-23-73 \\
04-08-86 \\
07-30-86\end{array}$ & & $\begin{array}{l}23.78 \\
29.12 \\
17.34 \\
22.00\end{array}$ & $\begin{array}{l}3,646 \\
3,641 \\
3,653 \\
3,648\end{array}$ & $\begin{array}{l}\mathrm{s} \\
\mathrm{s} \\
\mathrm{s} \\
\mathrm{s}\end{array}$ \\
\hline $7 \mathrm{~S} / 2 \mathrm{E}-22 \mathrm{~K} 3$ & $\begin{array}{l}10-23-69 \\
08-23-73 \\
04-08-86\end{array}$ & 3,560 & $\begin{array}{l}7.83 \\
8.89 \\
5.31\end{array}$ & $\begin{array}{l}3,552 \\
3,661 \\
3,555\end{array}$ & $\begin{array}{l}\mathbf{s} \\
\mathbf{s} \\
\mathbf{s}\end{array}$ \\
\hline $7 \mathrm{~S} / 2 \mathrm{E}-23 \mathrm{Gl}$ & $07-29-86$ & 3,690 & 27.80 & 3,662 & $\mathbf{s}$ \\
\hline $7 \mathrm{~S} / 2 \mathrm{E}-23 \mathrm{H} 1$ & $\begin{array}{l}01-07-86 \\
04-07-86 \\
07-17-86\end{array}$ & 3,670 & $\begin{array}{l}35.45 \\
34.47 \\
36.29\end{array}$ & $\begin{array}{l}3,635 \\
3,636 \\
3,634\end{array}$ & $\begin{array}{l}r \\
s \\
s\end{array}$ \\
\hline $7 \mathrm{~S} / 2 \mathrm{E}-23 \mathrm{~K} 1$ & $\begin{array}{l}11-29-51 \\
11-21-52 \\
05-07-53 \\
11-09-53\end{array}$ & $3,636.6$ & $\begin{array}{l}27.00 \\
21.50 \\
19.20 \\
19.90\end{array}$ & $\begin{array}{l}3,610 \\
3,615 \\
3,617 \\
3,617\end{array}$ & $\begin{array}{l}\mathrm{s} \\
\mathrm{s} \\
\mathrm{s} \\
\mathrm{s}\end{array}$ \\
\hline
\end{tabular}


SUPPLEMENTAL DATA B: Water levels--Continued

\begin{tabular}{|c|c|c|c|c|c|}
\hline $\begin{array}{l}\text { We11 } \\
\text { number }\end{array}$ & $\begin{array}{l}\text { Measurement } \\
\text { date }\end{array}$ & $\begin{array}{l}\text { Land- } \\
\text { surface } \\
\text { altitude } \\
\text { (feet) }\end{array}$ & $\begin{array}{c}\text { Depth } \\
\text { to water } \\
\text { (feet below } \\
\text { land surface) }\end{array}$ & $\begin{array}{l}\text { Water- } \\
\text { table } \\
\text { a1titude } \\
\text { (feet) }\end{array}$ & $\begin{array}{l}\text { Site } \\
\text { status }\end{array}$ \\
\hline $7 \mathrm{~S} / 2 \mathrm{E}-23 \mathrm{~K} 1$ & $\begin{array}{l}05-10-54 \\
07-26-60 \\
12-01-69 \\
08-31-73 \\
07-30-86\end{array}$ & $3,636.6$ & $\begin{array}{r}19.80 \\
22.81 \\
10.51 \\
29.90 \\
9.92\end{array}$ & $\begin{array}{l}3,617 \\
3,614 \\
3,616 \\
3,607 \\
3,627\end{array}$ & $\begin{array}{l}\mathrm{s} \\
\mathrm{s} \\
\mathrm{s} \\
\mathrm{p} \\
\mathrm{s}\end{array}$ \\
\hline $7 \mathrm{~S} / 2 \mathrm{E}-23 \mathrm{Q} 1$ & $\begin{array}{l}04-24-60 \\
12-01-69 \\
08-31-73 \\
07-16-86\end{array}$ & 3,620 & $\begin{array}{r}15.00 \\
11.43 \\
12.05 \\
2.78\end{array}$ & $\begin{array}{l}3,605 \\
3,609 \\
3,608 \\
3,617\end{array}$ & $\begin{array}{l}\mathrm{s} \\
\mathrm{s} \\
\mathrm{s} \\
\mathrm{s}\end{array}$ \\
\hline $7 \mathrm{~S} / 2 \mathrm{E}-24 \mathrm{P} 1$ & $\begin{array}{l}08-22-73 \\
08-01-86\end{array}$ & 3,780 & $\begin{array}{l}55.35 \\
30.90\end{array}$ & $\begin{array}{l}3,725 \\
3,749\end{array}$ & $\begin{array}{l}\mathrm{s} \\
\mathrm{s}\end{array}$ \\
\hline $7 \mathrm{~S} / 2 \mathrm{E}-25 \mathrm{~F} 1$ & $\begin{array}{l}01-10-86 \\
04-07-86 \\
07-14-86\end{array}$ & 3,675 & $\begin{array}{l}39.01 \\
37.99 \\
41.46\end{array}$ & $\begin{array}{l}3,636 \\
3,637 \\
3,634\end{array}$ & $\begin{array}{l}\mathrm{s} \\
\mathrm{s} \\
\mathrm{s}\end{array}$ \\
\hline $7 \mathrm{~S} / 2 \mathrm{E}-26 \mathrm{~B} 2$ & $07-29-86$ & 3,675 & 17.04 & 3,658 & $\mathbf{s}$ \\
\hline $7 \mathrm{~S} / 2 \mathrm{E}-28 \mathrm{Q} 1$ & $\begin{array}{l}06-10-70 \\
09-14-73 \\
02-05-86 \\
04-07-86 \\
07-14-86\end{array}$ & 3,450 & $\begin{array}{l}48.97 \\
66.00 \\
28.34 \\
19.73 \\
28.40\end{array}$ & $\begin{array}{l}3,401 \\
3,384 \\
3,422 \\
3,430 \\
3,422\end{array}$ & $\begin{array}{l}\mathrm{s} \\
\mathrm{p} \\
\mathrm{s} \\
\mathrm{s} \\
\mathrm{s}\end{array}$ \\
\hline $7 \mathrm{~S} / 2 \mathrm{E}-29 \mathrm{~B} 1$ & $\begin{array}{l}02-03-86 \\
04-08-86 \\
07-17-86\end{array}$ & 3,560 & $\begin{array}{l}31.80 \\
29.29 \\
37.71\end{array}$ & $\begin{array}{l}3,528 \\
3,531 \\
3,522\end{array}$ & $\begin{array}{l}\mathrm{s} \\
\mathrm{s} \\
\mathrm{s}\end{array}$ \\
\hline $7 \mathrm{~S} / 2 \mathrm{E}-32 \mathrm{~A} 3$ & $\begin{array}{l}01-21-86 \\
04-08-86 \\
07-17-86\end{array}$ & 3,430 & $\begin{array}{r}12.53 \\
9.80 \\
14.16\end{array}$ & $\begin{array}{l}3,417 \\
3,420 \\
3,416\end{array}$ & $\begin{array}{l}\mathrm{s} \\
\mathrm{p} \\
\mathrm{p}\end{array}$ \\
\hline $7 \mathrm{~S} / 2 \mathrm{E}-32 \mathrm{D} 2$ & $\begin{array}{l}01-21-86 \\
04-08-86 \\
07-17-86\end{array}$ & 3,430 & $\begin{array}{l}14.31 \\
13.44 \\
16.73\end{array}$ & $\begin{array}{l}3,416 \\
3,417 \\
3,413\end{array}$ & $\begin{array}{l}\mathrm{s} \\
\mathrm{s} \\
\mathrm{s}\end{array}$ \\
\hline $7 \mathrm{~S} / 2 \mathrm{E}-33 \mathrm{~N} 1$ & $\begin{array}{l}11-16-73 \\
11-20-85 \\
04-07-86 \\
07-14-86\end{array}$ & 3,430 & $\begin{array}{r}16.17 \\
0.43 \\
0.30 \\
0.41\end{array}$ & $\begin{array}{l}3,414 \\
3,430 \\
3,430 \\
3,430\end{array}$ & $\begin{array}{l}\mathrm{s} \\
\mathrm{s} \\
\mathrm{s} \\
\mathrm{s}\end{array}$ \\
\hline
\end{tabular}


SUPPLEMENTAL DATA B: Water levels--Continued

\begin{tabular}{|c|c|c|c|c|c|}
\hline $\begin{array}{l}\text { Well } \\
\text { number }\end{array}$ & $\begin{array}{l}\text { Measurement } \\
\text { date }\end{array}$ & $\begin{array}{l}\text { Land- } \\
\text { surface } \\
\text { altitude } \\
(\mathrm{feet})\end{array}$ & $\begin{array}{c}\text { Depth } \\
\text { to water } \\
\text { (feet below } \\
\text { land surface) }\end{array}$ & $\begin{array}{l}\text { Water- } \\
\text { table } \\
\text { altitude } \\
\text { (feet) }\end{array}$ & $\begin{array}{l}\text { Site } \\
\text { status }\end{array}$ \\
\hline $7 \mathrm{~S} / 2 \mathrm{E}-34 \mathrm{E} 1$ & $\begin{array}{l}08-28-73 \\
04-09-86 \\
07-14-86\end{array}$ & 3,580 & $\begin{array}{r}5.21 \\
-1.78 \\
-1.49\end{array}$ & $\begin{array}{l}3,575 \\
3,582 \\
3,581\end{array}$ & $\begin{array}{l}s \\
s \\
s\end{array}$ \\
\hline $7 \mathrm{~S} / 2 \mathrm{E}-36 \mathrm{~A} 1$ & $\begin{array}{l}01-07-86 \\
07-14-86\end{array}$ & 3,720 & $\begin{array}{l}36.87 \\
36.90\end{array}$ & $\begin{array}{l}3,683 \\
3,683\end{array}$ & $\begin{array}{l}s \\
s\end{array}$ \\
\hline $7 \mathrm{~S} / 2 \mathrm{E}-36 \mathrm{~J} 1$ & $\begin{array}{l}01-07-86 \\
07-14-86\end{array}$ & 3,910 & $\begin{array}{l}44.81 \\
43.95\end{array}$ & $\begin{array}{l}3,865 \\
3,866\end{array}$ & $\begin{array}{l}\mathrm{s} \\
\mathrm{s}\end{array}$ \\
\hline $7 \mathrm{~S} / 3 \mathrm{E}-4 \mathrm{H} 1$ & $\begin{array}{l}07-28-69 \\
08-08-73 \\
07-15-86\end{array}$ & 4,720 & $\begin{array}{r}8.92 \\
10.05 \\
7.52\end{array}$ & $\begin{array}{l}4,711 \\
4,710 \\
4,712\end{array}$ & $\begin{array}{l}\mathrm{s} \\
\mathbf{s} \\
\mathrm{s}\end{array}$ \\
\hline $7 \mathrm{~S} / 3 \mathrm{E}-4 \mathrm{H} 2$ & $\begin{array}{l}07-28-69 \\
08-08-73 \\
07-14-86\end{array}$ & 4,780 & $\begin{array}{l}21.09 \\
18.36 \\
23.46\end{array}$ & $\begin{array}{l}4,759 \\
4,752 \\
4,757\end{array}$ & $\begin{array}{l}s \\
s \\
s\end{array}$ \\
\hline $7 S / 3 E-7 C 2$ & $\begin{array}{l}08-05-69 \\
12-10-75 \\
01-22-76 \\
03-29-76 \\
05-27-76\end{array}$ & 4,055 & $\begin{array}{l}120.33 \\
119.48 \\
119.10 \\
118.74 \\
120.39\end{array}$ & $\begin{array}{l}3,935 \\
3,936 \\
3,936 \\
3,936 \\
3,935\end{array}$ & $\begin{array}{l}\mathrm{s} \\
\mathrm{s} \\
\mathrm{s} \\
\mathrm{s} \\
\mathrm{s}\end{array}$ \\
\hline & $\begin{array}{l}07-07-76 \\
08-04-76 \\
09-02-76 \\
10-12-76 \\
11-18-76\end{array}$ & & $\begin{array}{l}124.75 \\
123.97 \\
122.46 \\
120.87 \\
120.26\end{array}$ & $\begin{array}{l}3,930 \\
3,931 \\
3,933 \\
3,934 \\
3,935\end{array}$ & $\begin{array}{l}\mathrm{s} \\
\mathrm{s} \\
\mathrm{s} \\
\mathrm{s} \\
\mathrm{s}\end{array}$ \\
\hline & $\begin{array}{l}12-16-76 \\
02-04-77 \\
03-24-77 \\
04-21-77 \\
06-08-77\end{array}$ & & $\begin{array}{l}120.05 \\
119.80 \\
119.75 \\
120.24 \\
120.63\end{array}$ & $\begin{array}{l}3,935 \\
3,935 \\
3,935 \\
3,935 \\
3,934\end{array}$ & $\begin{array}{l}\mathrm{s} \\
\mathrm{s} \\
\mathrm{s} \\
\mathrm{s} \\
\mathrm{s}\end{array}$ \\
\hline & $\begin{array}{l}07-21-77 \\
08-24-77 \\
09-22-77 \\
11-21-77 \\
12-19-77\end{array}$ & & $\begin{array}{l}125.55 \\
124.40 \\
121.50 \\
121.31 \\
121.32\end{array}$ & $\begin{array}{l}3,929 \\
3,931 \\
3,934 \\
3,934 \\
3,934\end{array}$ & $\begin{array}{l}s \\
s \\
s \\
s \\
s\end{array}$ \\
\hline
\end{tabular}


SUPPLEMENTAL DATA B: Water levels--Continued

\begin{tabular}{|c|c|c|c|c|c|}
\hline $\begin{array}{c}\text { Well } \\
\text { number }\end{array}$ & $\begin{array}{c}\text { Measurement } \\
\text { date }\end{array}$ & $\begin{array}{l}\text { Land- } \\
\text { surface } \\
\text { altitude } \\
\text { (feet) }\end{array}$ & $\begin{array}{c}\text { Depth } \\
\text { to water } \\
\text { (feet below } \\
\text { land surface) }\end{array}$ & $\begin{array}{l}\text { Water- } \\
\text { table } \\
\text { altitude } \\
\text { (feet) }\end{array}$ & $\begin{array}{c}\text { Site } \\
\text { status }\end{array}$ \\
\hline $7 S / 3 E-7 C 2$ & $\begin{array}{l}01-25-78 \\
02-16-78 \\
03-08-78 \\
07-19-78 \\
09-07-78\end{array}$ & 4,055 & $\begin{array}{l}125.88 \\
123.89 \\
121.11 \\
123.44 \\
126.13\end{array}$ & $\begin{array}{l}3,929 \\
3,931 \\
3,934 \\
3,932 \\
3,929\end{array}$ & $\begin{array}{l}\mathrm{s} \\
\mathrm{s} \\
\mathrm{s} \\
\mathrm{s} \\
\mathrm{s}\end{array}$ \\
\hline & $\begin{array}{l}10-10-78 \\
01-11-79 \\
02-10-79 \\
03-30-79 \\
04-25-79\end{array}$ & & $\begin{array}{l}122.83 \\
122.39 \\
121.90 \\
121.42 \\
124.00\end{array}$ & $\begin{array}{l}3,932 \\
3,933 \\
3,933 \\
3,934 \\
3,931\end{array}$ & $\begin{array}{l}s \\
s \\
s \\
s \\
r\end{array}$ \\
\hline & $\begin{array}{l}05-14-79 \\
08-13-79 \\
09-14-79 \\
10-16-79 \\
11-15-79\end{array}$ & & $\begin{array}{l}122.01 \\
129.75 \\
123.67 \\
124.27 \\
122.35\end{array}$ & $\begin{array}{l}3,933 \\
3,925 \\
3,931 \\
3,931 \\
3,933\end{array}$ & $\begin{array}{l}r \\
r \\
r \\
s \\
s\end{array}$ \\
\hline & $\begin{array}{l}12-20-79 \\
01-23-80 \\
02-28-80 \\
03-31-80 \\
05-14-80\end{array}$ & & $\begin{array}{l}131.29 \\
130.72 \\
120.45 \\
120.32 \\
120.02\end{array}$ & $\begin{array}{l}3,924 \\
3,924 \\
3,935 \\
3,935 \\
3,935\end{array}$ & $\begin{array}{l}r \\
s \\
s \\
s \\
s\end{array}$ \\
\hline & $\begin{array}{l}07-02-80 \\
07-30-80 \\
09-03-80 \\
10-10-80 \\
11-07-80\end{array}$ & & $\begin{array}{l}123.87 \\
124.04 \\
125.97 \\
124.51 \\
122.37\end{array}$ & $\begin{array}{l}3,931 \\
3,931 \\
3,929 \\
3,930 \\
3,933\end{array}$ & $\begin{array}{l}\mathrm{s} \\
\mathrm{s} \\
\mathrm{s} \\
\mathrm{s} \\
\mathrm{s}\end{array}$ \\
\hline & $\begin{array}{l}12-11-80 \\
01-27-81 \\
02-17-81 \\
03-10-81 \\
04-07-81\end{array}$ & & $\begin{array}{l}121.18 \\
119.99 \\
119.59 \\
119.28 \\
120.38\end{array}$ & $\begin{array}{l}3,934 \\
3,935 \\
3,935 \\
3,936 \\
3,935\end{array}$ & $\begin{array}{l}s \\
s \\
s \\
s \\
s\end{array}$ \\
\hline & $\begin{array}{l}06-04-81 \\
07-09-81 \\
08-06-81 \\
09-15-81 \\
10-15-81\end{array}$ & & $\begin{array}{l}119.93 \\
123.24 \\
127.04 \\
121.70 \\
118.27\end{array}$ & $\begin{array}{l}3,935 \\
3,932 \\
3,928 \\
3,933 \\
3,937\end{array}$ & $\begin{array}{l}\text { s } \\
\text { s } \\
\text { s } \\
\text { s } \\
\text { s }\end{array}$ \\
\hline
\end{tabular}


SUPPLEMENTAL DATA B: Water levels--Continued

\begin{tabular}{|c|c|c|c|c|c|}
\hline $\begin{array}{l}\text { We11 } \\
\text { number }\end{array}$ & $\begin{array}{c}\text { Measurement } \\
\text { date }\end{array}$ & $\begin{array}{l}\text { Land- } \\
\text { surface } \\
\text { altitude } \\
\text { (feet) }\end{array}$ & $\begin{array}{c}\text { Depth } \\
\text { to water } \\
\text { (feet below } \\
\text { land surface) }\end{array}$ & $\begin{array}{l}\text { Water- } \\
\text { table } \\
\text { altitude } \\
\text { (feet) }\end{array}$ & $\begin{array}{l}\text { Site } \\
\text { status }\end{array}$ \\
\hline \multirow[t]{4}{*}{$7 S / 3 E-7 C 2$} & $\begin{array}{l}12-28-81 \\
03-03-82 \\
04-16-12 \\
06-30-82 \\
08-24-82\end{array}$ & 4,055 & $\begin{array}{l}118.93 \\
117.93 \\
118.04 \\
120.84 \\
124.40\end{array}$ & $\begin{array}{l}3,936 \\
3,937 \\
3,937 \\
3,934 \\
3,931\end{array}$ & $\begin{array}{l}\mathrm{r} \\
\mathrm{s} \\
\mathrm{s} \\
\mathrm{r} \\
\mathrm{s}\end{array}$ \\
\hline & $\begin{array}{l}12-02-82 \\
03-24-83 \\
06-28-83 \\
10-05-83 \\
12-09-83\end{array}$ & & $\begin{array}{l}119.62 \\
117.40 \\
121.39 \\
120.11 \\
116.72\end{array}$ & $\begin{array}{l}3,935 \\
3,938 \\
3,934 \\
3,935 \\
3,938\end{array}$ & $\begin{array}{l}r \\
s \\
r \\
r \\
s\end{array}$ \\
\hline & $\begin{array}{l}03-15-84 \\
06-26-84 \\
10-02-84 \\
12-03-84 \\
03-15-85\end{array}$ & & $\begin{array}{l}115.51 \\
118.41 \\
115.99 \\
115.07 \\
113.76\end{array}$ & $\begin{array}{l}3,939 \\
3,937 \\
3,939 \\
3,940 \\
3,941\end{array}$ & $\begin{array}{l}\mathrm{s} \\
\mathrm{s} \\
\mathrm{s} \\
\mathrm{s} \\
\mathrm{s}\end{array}$ \\
\hline & $\begin{array}{l}09-12-85 \\
07-30-86\end{array}$ & & $\begin{array}{l}115.76 \\
113.65\end{array}$ & $\begin{array}{l}3,939 \\
3,941\end{array}$ & $\begin{array}{l}\mathrm{s} \\
\mathrm{s}\end{array}$ \\
\hline $7 S / 3 E-7 F 1$ & $\begin{array}{l}08-05-69 \\
08-21-73 \\
07-16-86\end{array}$ & 4,090 & $\begin{array}{l}134.88 \\
142.70 \\
112.80\end{array}$ & $\begin{array}{l}3,955 \\
3,947 \\
3,977\end{array}$ & $\begin{array}{l}\mathrm{s} \\
\mathrm{s} \\
\mathrm{s}\end{array}$ \\
\hline $7 \mathrm{~S} / 3 \mathrm{E}-8 \mathrm{~L} 1$ & $\begin{array}{l}08-01-69 \\
04-19-73 \\
08-17-73 \\
07-30-86\end{array}$ & 4,160 & $\begin{array}{r}92.66 \\
96.24 \\
120.20 \\
82.65\end{array}$ & $\begin{array}{l}4,067 \\
4,064 \\
4,040 \\
4,077\end{array}$ & $\begin{array}{l}\mathrm{s} \\
\mathrm{s} \\
\mathrm{p} \\
\mathrm{s}\end{array}$ \\
\hline 7S / 3E-9D1 & $\begin{array}{l}08-24-60 \\
07-31-69 \\
08-16-73 \\
07-29-86\end{array}$ & 4,290 & $\begin{array}{l}140.00 \\
122.37 \\
122.94 \\
130.78\end{array}$ & $\begin{array}{l}4,150 \\
4,168 \\
4,167 \\
4,159\end{array}$ & $\begin{array}{l}\mathrm{s} \\
\mathrm{s} \\
\mathrm{s} \\
\mathrm{s}\end{array}$ \\
\hline $7 \mathrm{~S} / 3 \mathrm{E}-9 \mathrm{E} 1$ & $\begin{array}{l}08-24-60 \\
06-10-70 \\
08-16-73 \\
07-29-86\end{array}$ & 4,220 & $\begin{array}{l}117.10 \\
149.73 \\
148.59 \\
110.16\end{array}$ & $\begin{array}{l}4,103 \\
4,070 \\
4,071 \\
4,110\end{array}$ & $\begin{array}{l}\mathrm{s} \\
\mathrm{s} \\
\mathrm{s} \\
\mathrm{s}\end{array}$ \\
\hline
\end{tabular}


SUPPLEMENTAL DATA B: Water levels--Continued

\begin{tabular}{|c|c|c|c|c|c|}
\hline $\begin{array}{l}\text { Well } \\
\text { number }\end{array}$ & $\begin{array}{c}\text { Measurement } \\
\text { date }\end{array}$ & $\begin{array}{l}\text { Land- } \\
\text { surface } \\
\text { altitude } \\
(\text { feet })\end{array}$ & $\begin{array}{c}\text { Depth } \\
\text { to water } \\
\text { (feet below } \\
\text { land surface) }\end{array}$ & $\begin{array}{l}\text { Water- } \\
\text { table } \\
\text { altitude } \\
\text { (feet) }\end{array}$ & $\begin{array}{l}\text { Site } \\
\text { status }\end{array}$ \\
\hline $7 \mathrm{~S} / 3 \mathrm{E}-9 \mathrm{~F} 1$ & $\begin{array}{l}07-30-69 \\
12-08-71 \\
04-19-73 \\
08-21-73 \\
07-31-86\end{array}$ & 4,280 & $\begin{array}{l}170.25 \\
152.74 \\
152.84 \\
179.89 \\
192.13\end{array}$ & $\begin{array}{l}4,110 \\
4,127 \\
4,127 \\
4,100 \\
4,088\end{array}$ & $\begin{array}{l}\mathrm{s} \\
\mathrm{s} \\
\mathrm{s} \\
\mathrm{s} \\
\mathrm{s}\end{array}$ \\
\hline $7 S / 3 E-9 P 4$ & $\begin{array}{l}07-29-69 \\
08-16-73 \\
07-16-86\end{array}$ & 4,120 & $\begin{array}{l}56.70 \\
69.38 \\
63.70\end{array}$ & $\begin{array}{l}4,063 \\
4,051 \\
4,056\end{array}$ & $\begin{array}{l}\mathbf{s} \\
\mathbf{s} \\
\mathbf{s}\end{array}$ \\
\hline $7 \mathrm{~S} / 3 \mathrm{E}-10 \mathrm{~B} 1$ & $\begin{array}{l}07-24-69 \\
07-15-86\end{array}$ & 4,360 & $\begin{array}{l}28.57 \\
26.15\end{array}$ & $\begin{array}{l}4,331 \\
4,334\end{array}$ & $\begin{array}{l}\mathrm{s} \\
\mathrm{s}\end{array}$ \\
\hline $7 \mathrm{~S} / 3 \mathrm{E}-10 \mathrm{C} 1$ & $\begin{array}{l}10-05-60 \\
07-24-69 \\
08-08-73 \\
07-17-86\end{array}$ & 4,390 & $\begin{array}{r}14.84 \\
6.00 \\
17.63 \\
15.75\end{array}$ & $\begin{array}{l}4,375 \\
4,384 \\
4,372 \\
4,374\end{array}$ & $\begin{array}{l}\mathrm{s} \\
\mathrm{s} \\
\mathrm{s} \\
\mathrm{s}\end{array}$ \\
\hline $7 \mathrm{~S} / 3 \mathrm{E}-10 \mathrm{G} 1$ & $07-16-86$ & 4,280 & 413.19 & 3,867 & s \\
\hline $7 \mathrm{~S} / 3 \mathrm{E}-10 \mathrm{~J} 1$ & $\begin{array}{l}07-24-69 \\
08-06-73 \\
07-15-86\end{array}$ & 4,180 & $\begin{array}{l}186.35 \\
164.70 \\
183.33\end{array}$ & $\begin{array}{l}3,994 \\
4,015 \\
3,997\end{array}$ & $\begin{array}{l}\mathbf{s} \\
\mathbf{s} \\
\mathbf{s}\end{array}$ \\
\hline $7 \mathrm{~S} / 3 \mathrm{E}-10 \mathrm{M} 2$ & $\begin{array}{l}09-09-60 \\
08-08-73 \\
07-16-86\end{array}$ & 4,250 & $\begin{array}{r}179.50 \\
265.92 \\
49.82\end{array}$ & $\begin{array}{l}4,070 \\
3,984 \\
4,200\end{array}$ & $\begin{array}{l}\mathrm{s} \\
\mathrm{p} \\
\mathrm{s}\end{array}$ \\
\hline $\begin{array}{l}7 S / 3 E-11 N 3 \\
7 S / 3 E-11 N 4 \\
7 S / 3 E-11 P 3\end{array}$ & $\begin{array}{l}07-16-86 \\
07-16-86 \\
07-17-86\end{array}$ & $\begin{array}{l}4,150 \\
4,143 \\
4,145\end{array}$ & $\begin{array}{l}275.91 \\
295.12 \\
301.35\end{array}$ & $\begin{array}{l}3,874 \\
3,848 \\
3,843\end{array}$ & $\begin{array}{l}\mathrm{s} \\
\mathrm{r} \\
\mathrm{p}\end{array}$ \\
\hline $7 \mathrm{~S} / 3 \mathrm{E}-13 \mathrm{D} 3$ & $\begin{array}{l}11-03-53 \\
08-04-60 \\
07-23-69 \\
08-07-73 \\
07-15-86\end{array}$ & 4,230 & $\begin{array}{r}6.70 \\
13.71 \\
6.75 \\
2.06 \\
11.68\end{array}$ & $\begin{array}{l}4,223 \\
4,216 \\
4,223 \\
4,228 \\
4,218\end{array}$ & $\begin{array}{l}\mathrm{s} \\
\mathrm{r} \\
\mathrm{s} \\
\mathrm{s} \\
\mathrm{r}\end{array}$ \\
\hline
\end{tabular}


SUPPLEMENTAL DATA B: Water levels--Continued

\begin{tabular}{|c|c|c|c|c|c|}
\hline $\begin{array}{l}\text { We11 } \\
\text { number }\end{array}$ & $\begin{array}{c}\text { Measurement } \\
\text { date }\end{array}$ & $\begin{array}{l}\text { Land- } \\
\text { surface } \\
\text { altitude } \\
(\text { feet) }\end{array}$ & $\begin{array}{l}\text { Depth } \\
\text { to water } \\
\text { (feet below } \\
\text { land surface) }\end{array}$ & $\begin{array}{l}\text { Water- } \\
\text { table } \\
\text { altitude } \\
\text { (feet) }\end{array}$ & $\begin{array}{l}\text { Site } \\
\text { status }\end{array}$ \\
\hline $\begin{array}{l}7 \mathrm{~S} / 3 \mathrm{E}-14 \mathrm{C} 2 \\
7 \mathrm{~S} / 3 \mathrm{E}-14 \mathrm{D} 1\end{array}$ & $\begin{array}{l}07-17-86 \\
07-17-86\end{array}$ & $\begin{array}{l}4,070 \\
4,060\end{array}$ & $\begin{array}{l}255.82 \\
255.38\end{array}$ & $\begin{array}{l}3,814 \\
3,805\end{array}$ & $\begin{array}{l}\mathrm{p} \\
\mathrm{p}\end{array}$ \\
\hline $7 S / 3 E-14 P 3$ & $\begin{array}{l}08-06-73 \\
08-20-79 \\
09-14-79 \\
10-16-79 \\
11-15-79\end{array}$ & 4,030 & $\begin{array}{l}74.98 \\
88.79 \\
88.85 \\
89.13 \\
91.98\end{array}$ & $\begin{array}{l}3,955 \\
3,941 \\
3,941 \\
3,941 \\
3,938\end{array}$ & $\begin{array}{l}\mathrm{s} \\
\mathrm{s} \\
\mathrm{s} \\
\mathrm{s} \\
\mathrm{s}\end{array}$ \\
\hline & $\begin{array}{l}12-20-79 \\
01-23-80 \\
02-28-80 \\
03-31-80 \\
05-14-80\end{array}$ & & $\begin{array}{l}89.73 \\
89.35 \\
95.58 \\
89.80 \\
88.77\end{array}$ & $\begin{array}{l}3,940 \\
3,941 \\
3,934 \\
3,940 \\
3,941\end{array}$ & $\begin{array}{l}s \\
s \\
s \\
s \\
s\end{array}$ \\
\hline & $\begin{array}{l}07-02-80 \\
07-30-80 \\
07-03-80 \\
10-10-80 \\
11-07-80\end{array}$ & & $\begin{array}{l}87.52 \\
86.90 \\
86.14 \\
86.37 \\
85.90\end{array}$ & $\begin{array}{l}3,942 \\
3,943 \\
3,944 \\
3,944 \\
3,944\end{array}$ & $\begin{array}{l}s \\
s \\
s \\
s \\
r\end{array}$ \\
\hline & $\begin{array}{l}12-11-80 \\
01-27-81 \\
02-17-81 \\
03-10-81 \\
04-07-81\end{array}$ & & $\begin{array}{l}85.51 \\
86.59 \\
84.87 \\
85.00 \\
89.80\end{array}$ & $\begin{array}{l}3,944 \\
3,943 \\
3,945 \\
3,945 \\
3,940\end{array}$ & $\begin{array}{l}s \\
s \\
s \\
s \\
r\end{array}$ \\
\hline & $\begin{array}{l}06-04-81 \\
07-08-81 \\
07-09-81 \\
08-06-81 \\
09-15-81\end{array}$ & & $\begin{array}{l}86.73 \\
90.00 \\
86.09 \\
92.20 \\
87.59\end{array}$ & $\begin{array}{l}3,943 \\
3,940 \\
3,944 \\
3,938 \\
3,942\end{array}$ & $\begin{array}{l}\mathrm{s} \\
\mathrm{s} \\
\mathrm{s} \\
\mathrm{r} \\
\mathrm{s}\end{array}$ \\
\hline & $\begin{array}{l}10-15-81 \\
12-28-81 \\
03-03-82 \\
04-12-82 \\
06-30-82\end{array}$ & & $\begin{array}{l}88.10 \\
88.51 \\
88.52 \\
88.30 \\
92.44\end{array}$ & $\begin{array}{l}3,942 \\
3,941 \\
3,941 \\
3,942 \\
3,938\end{array}$ & $\begin{array}{l}\mathbf{s} \\
\mathrm{r} \\
\mathrm{r} \\
\mathrm{s} \\
\mathrm{r}\end{array}$ \\
\hline
\end{tabular}


SUPPLEMENTAL DATA B: Water levels--Continued

\begin{tabular}{|c|c|c|c|c|c|}
\hline $\begin{array}{l}\text { Wel1 } \\
\text { number }\end{array}$ & $\begin{array}{c}\text { Measurement } \\
\text { date }\end{array}$ & $\begin{array}{l}\text { Land- } \\
\text { surface } \\
\text { a1titude } \\
\text { (feet) }\end{array}$ & $\begin{array}{c}\text { Depth } \\
\text { to water } \\
\text { (feet below } \\
\text { land surface) }\end{array}$ & $\begin{array}{l}\text { Water- } \\
\text { table } \\
\text { altitude } \\
\text { (feet) }\end{array}$ & $\begin{array}{l}\text { Site } \\
\text { status }\end{array}$ \\
\hline $7 \mathrm{~S} / 3 \mathrm{E}-14 \mathrm{P} 3$ & $\begin{array}{l}08-24-82 \\
12-02-82 \\
03-24-83 \\
06-28-83 \\
10-05-83\end{array}$ & 4,030 & $\begin{array}{l}91.60 \\
95.69 \\
95.68 \\
92.97 \\
90.27\end{array}$ & $\begin{array}{l}3,938 \\
3,934 \\
3,934 \\
3,937 \\
3,940\end{array}$ & $\begin{array}{l}r \\
r \\
r \\
r \\
r\end{array}$ \\
\hline & $\begin{array}{l}12-09-83 \\
04-07-86 \\
07-16-86\end{array}$ & & $\begin{array}{l}90.70 \\
95.52 \\
95.71\end{array}$ & $\begin{array}{l}3,939 \\
3,934 \\
3,934\end{array}$ & $\begin{array}{l}r \\
r \\
s\end{array}$ \\
\hline $7 S / 3 E-15 D 2$ & $\begin{array}{l}09-08-60 \\
07-30-86\end{array}$ & 4,100 & $\begin{array}{l}94.39 \\
94.29\end{array}$ & $\begin{array}{l}4,006 \\
4,006\end{array}$ & $\begin{array}{l}\mathrm{s} \\
\mathrm{s}\end{array}$ \\
\hline $7 \mathrm{~S} / 3 \mathrm{E}-15 \mathrm{M} 1$ & $\begin{array}{l}07-29-69 \\
07-30-86\end{array}$ & 3,995 & $\begin{array}{l}52.65 \\
52.22\end{array}$ & $\begin{array}{l}3,942 \\
3,943\end{array}$ & $\begin{array}{l}s \\
s\end{array}$ \\
\hline $7 \mathrm{~S} / 3 \mathrm{E}-15 \mathrm{P} 1$ & $\begin{array}{l}05-22-53 \\
11-24-53 \\
04-24-54 \\
08-03-60 \\
07-29-69\end{array}$ & $3,935.68$ & $\begin{array}{l}30.00 \\
-2.80 \\
25.20 \\
29.22 \\
19.12\end{array}$ & $\begin{array}{l}3,906 \\
3,938 \\
3,910 \\
3,906 \\
3,917\end{array}$ & $\begin{array}{l}\mathrm{s} \\
\mathrm{s} \\
\mathrm{p} \\
\mathrm{s} \\
\mathrm{s}\end{array}$ \\
\hline & $\begin{array}{l}08-09-73 \\
04-08-86 \\
07-17-86\end{array}$ & & $\begin{array}{l}22.18 \\
11.60 \\
12.10\end{array}$ & $\begin{array}{l}3,913 \\
3,924 \\
3,924\end{array}$ & $\begin{array}{l}\mathrm{s} \\
\mathrm{r} \\
\mathrm{s}\end{array}$ \\
\hline $7 \mathrm{~S} / 3 \mathrm{E}-16 \mathrm{~F} 4$ & $\begin{array}{l}01-24-86 \\
04-07-86 \\
07-16-86\end{array}$ & 3,940 & $\begin{array}{l}27.50 \\
26.07 \\
27.32\end{array}$ & $\begin{array}{l}3,912 \\
3,914 \\
3,913\end{array}$ & $\begin{array}{l}\mathrm{s} \\
\mathrm{s} \\
\mathrm{s}\end{array}$ \\
\hline $7 \mathrm{~S} / 3 \mathrm{E}-16 \mathrm{~L} 1$ & $\begin{array}{l}07-28-60 \\
07-30-69 \\
08-16-73 \\
07-30-86\end{array}$ & 3,975 & $\begin{array}{l}61.40 \\
48.47 \\
50.73 \\
46.10\end{array}$ & $\begin{array}{l}3,914 \\
3,927 \\
3,924 \\
3,929\end{array}$ & $\begin{array}{l}s \\
s \\
s \\
s\end{array}$ \\
\hline $7 \mathrm{~S} / 3 \mathrm{E}-16 \mathrm{~N} 5$ & $\begin{array}{l}08-04-69 \\
11-18-71 \\
05-30-72 \\
09-27-72 \\
04-19-73 \\
07-29-86\end{array}$ & 3,930 & $\begin{array}{l}90.59 \\
90.58 \\
91.20 \\
93.09 \\
90.83 \\
74.75\end{array}$ & $\begin{array}{l}3,839 \\
3,839 \\
3,839 \\
3,837 \\
3,839 \\
3,855\end{array}$ & $\begin{array}{l}\mathrm{s} \\
\mathrm{s} \\
\mathrm{s} \\
\mathrm{s} \\
\mathrm{s} \\
\mathrm{s}\end{array}$ \\
\hline
\end{tabular}


SUPPLEMENTAL DATA B: Water levels--Continued

\begin{tabular}{|c|c|c|c|c|c|}
\hline $\begin{array}{l}\text { We11 } \\
\text { number }\end{array}$ & $\begin{array}{c}\text { Measurement } \\
\text { date }\end{array}$ & $\begin{array}{l}\text { Land- } \\
\text { surface } \\
\text { altitude } \\
\text { (feet) }\end{array}$ & $\begin{array}{c}\text { Depth } \\
\text { to water } \\
\text { (feet below } \\
\text { land surface) }\end{array}$ & $\begin{array}{l}\text { Water- } \\
\text { table } \\
\text { altitude } \\
\text { (feet) }\end{array}$ & $\begin{array}{l}\text { Site } \\
\text { status }\end{array}$ \\
\hline $7 \mathrm{~S} / 3 \mathrm{E}-17 \mathrm{Al}$ & $\begin{array}{l}08-05-69 \\
07-31-86\end{array}$ & 4,065 & $\begin{array}{l}87.85 \\
70.30\end{array}$ & $\begin{array}{l}3,977 \\
3,995\end{array}$ & $\begin{array}{l}s \\
s\end{array}$ \\
\hline $7 \mathrm{~S} / 3 \mathrm{E}-17 \mathrm{~B} 2$ & $\begin{array}{l}08-11-60 \\
08-31-62 \\
08-05-69 \\
08-15-73 \\
04-07-86 \\
07-16-86\end{array}$ & 4,075 & $\begin{array}{l}81.00 \\
67.00 \\
77.05 \\
80.46 \\
70.90 \\
75.00\end{array}$ & $\begin{array}{l}3,994 \\
4,008 \\
3,998 \\
3,995 \\
4,004 \\
4,000\end{array}$ & $\begin{array}{l}\text { s } \\
s \\
s \\
s \\
s \\
s\end{array}$ \\
\hline $7 \mathrm{~S} / 3 \mathrm{E}-17 \mathrm{H} 1$ & $07-31-86$ & 4,020 & 87.72 & 3,932 & s \\
\hline $7 \mathrm{~S} / 3 \mathrm{E}-18 \mathrm{~B} 1$ & $\begin{array}{l}02-04-86 \\
04-07-86 \\
07-15-86\end{array}$ & 3,900 & $\begin{array}{l}211.03 \\
216.99 \\
278.80\end{array}$ & $\begin{array}{l}3,689 \\
3,683 \\
3,621\end{array}$ & $\begin{array}{l}s \\
s \\
p\end{array}$ \\
\hline $7 \mathrm{~S} / 3 \mathrm{E}-18 \mathrm{R} 1$ & $\begin{array}{l}08-07-69 \\
07-31-86\end{array}$ & 4,030 & $\begin{array}{r}145.30 \\
92.23\end{array}$ & $\begin{array}{l}3,885 \\
3,938\end{array}$ & $\begin{array}{l}s \\
s\end{array}$ \\
\hline $7 S / 3 E-19 D 1$ & $\begin{array}{l}04-08-86 \\
07-30-86 \\
07-31-86\end{array}$ & 3,840 & $\begin{array}{l}35.10 \\
44.24 \\
37.27\end{array}$ & $\begin{array}{l}3,805 \\
3,796 \\
3,803\end{array}$ & $\begin{array}{l}\mathrm{s} \\
\mathrm{p} \\
\mathrm{s}\end{array}$ \\
\hline $7 S / 3 E-20 C 2$ & $07-16-86$ & 3,958 & 66.85 & 3,891 & s \\
\hline $7 S / 3 E-20 E 2$ & $\begin{array}{l}10-22-69 \\
04-08-86 \\
07-18-86\end{array}$ & 3,900 & $\begin{array}{l}79.00 \\
42.70 \\
44.56\end{array}$ & $\begin{array}{l}3,821 \\
3,857 \\
3,855\end{array}$ & $\begin{array}{l}\mathrm{s} \\
\mathrm{s} \\
\mathrm{s}\end{array}$ \\
\hline $7 S / 3 E-21 C 2$ & $\begin{array}{l}10-05-60 \\
10-23-69 \\
07-29-86\end{array}$ & 3,920 & $\begin{array}{l}81.00 \\
96.05 \\
64.32\end{array}$ & $\begin{array}{l}3,839 \\
3,824 \\
3,856\end{array}$ & $\begin{array}{l}s \\
s \\
s\end{array}$ \\
\hline $7 \mathrm{~S} / 3 \mathrm{E}-21 \mathrm{~J} 2$ & $\begin{array}{l}11-30-50 \\
11-29-51 \\
11-18-52 \\
05-26-53 \\
04-22-54\end{array}$ & $3,849.25$ & $\begin{array}{r}8.50 \\
31.20 \\
13.00 \\
26.00 \\
31.90\end{array}$ & $\begin{array}{l}3,841 \\
3,818 \\
3,836 \\
3,823 \\
3,817\end{array}$ & $\begin{array}{l}s \\
s \\
s \\
s \\
s\end{array}$ \\
\hline & $\begin{array}{l}10-19-54 \\
10-28-69 \\
08-10-73 \\
08-20-86\end{array}$ & & $\begin{array}{l}25.30 \\
44.80 \\
98.00 \\
72.79\end{array}$ & $\begin{array}{l}3,824 \\
3,804 \\
3,751 \\
3,776\end{array}$ & $\begin{array}{l}\mathrm{s} \\
\mathrm{s} \\
\mathrm{p} \\
\mathrm{s}\end{array}$ \\
\hline
\end{tabular}


SUPPLEMENTAL DATA B: Water levels--Continued

\begin{tabular}{|c|c|c|c|c|c|}
\hline $\begin{array}{l}\text { We11 } \\
\text { number }\end{array}$ & $\begin{array}{c}\text { Measurement } \\
\text { date }\end{array}$ & $\begin{array}{l}\text { Land- } \\
\text { surface } \\
\text { altitude } \\
\text { (feet) }\end{array}$ & $\begin{array}{c}\text { Depth } \\
\text { to water } \\
\text { (feet below } \\
\text { land surface) }\end{array}$ & $\begin{array}{l}\text { Water- } \\
\text { table } \\
\text { altitude } \\
\text { (feet) }\end{array}$ & $\begin{array}{l}\text { Site } \\
\text { status }\end{array}$ \\
\hline $7 \mathrm{~S} / 3 \mathrm{E}-21 \mathrm{~L} 1$ & $\begin{array}{l}11-13-52 \\
05-27-53 \\
11-18-53 \\
11-24-53 \\
04-22-54\end{array}$ & $3,842.51$ & $\begin{array}{l}17.50 \\
34.50 \\
17.50 \\
44.70 \\
49.00\end{array}$ & $\begin{array}{l}3,825 \\
3,808 \\
3,825 \\
3,798 \\
3,794\end{array}$ & $\begin{array}{l}\mathrm{s} \\
\mathrm{p} \\
\mathrm{s} \\
\mathrm{p} \\
\mathrm{p}\end{array}$ \\
\hline & $\begin{array}{l}08-22-60 \\
08-15-73 \\
07-16-86\end{array}$ & & $\begin{array}{l}55.62 \\
64.80 \\
18.20\end{array}$ & $\begin{array}{l}3,787 \\
3,778 \\
3,824\end{array}$ & $\begin{array}{l}\mathrm{p} \\
\mathrm{p} \\
\mathrm{s}\end{array}$ \\
\hline $7 \mathrm{~S} / 3 \mathrm{E}-22 \mathrm{H} 1$ & $\begin{array}{l}10-29-69 \\
08-09-73 \\
08-01-86\end{array}$ & 3,940 & $\begin{array}{l}8.25 \\
8.66 \\
9.50\end{array}$ & $\begin{array}{l}3,932 \\
3,931 \\
3,930\end{array}$ & $\begin{array}{l}\mathrm{s} \\
\mathrm{s} \\
\mathrm{s}\end{array}$ \\
\hline $7 \mathrm{~S} / 3 \mathrm{E}-22 \mathrm{~N} 1$ & $\begin{array}{l}01-20-50 \\
11-20-51 \\
11-18-52 \\
03-26-53 \\
11-24-53\end{array}$ & $3,861.29$ & $\begin{array}{l}16.20 \\
18.00 \\
18.60 \\
22.20 \\
26.20\end{array}$ & $\begin{array}{l}3,845 \\
3,843 \\
3,843 \\
3,839 \\
3,835\end{array}$ & $\begin{array}{l}\mathrm{s} \\
\mathrm{s} \\
\mathrm{s} \\
\mathrm{s} \\
\mathrm{s}\end{array}$ \\
\hline & $\begin{array}{l}04-22-54 \\
10-19-54 \\
08-10-60 \\
10-28-69 \\
08-08-73 \\
08-01-86\end{array}$ & & $\begin{array}{l}25.00 \\
25.80 \\
42.06 \\
45.42 \\
55.91 \\
39.70\end{array}$ & $\begin{array}{l}3,836 \\
3,835 \\
3,819 \\
3,816 \\
3,805 \\
3,822\end{array}$ & $\begin{array}{l}\mathrm{s} \\
\mathrm{s} \\
\mathrm{p} \\
\mathrm{s} \\
\mathrm{s} \\
\mathrm{s}\end{array}$ \\
\hline $7 \mathrm{~S} / 3 \mathrm{E}-22 \mathrm{R} 1$ & $\begin{array}{l}10-30-69 \\
08-10-73 \\
07-17-86 \\
08-01-86\end{array}$ & 3,920 & $\begin{array}{l}43.17 \\
44.45 \\
49.55 \\
46.94\end{array}$ & $\begin{array}{l}3,877 \\
3,876 \\
3,870 \\
3,873\end{array}$ & $\begin{array}{l}\mathrm{s} \\
\mathrm{s} \\
\mathrm{r} \\
\mathrm{s}\end{array}$ \\
\hline $7 \mathrm{~S} / 3 \mathrm{E}-23 \mathrm{~B} 1$ & $\begin{array}{l}07-13-69 \\
08-01-86\end{array}$ & 4,060 & $\begin{array}{l}62.72 \\
52.00\end{array}$ & $\begin{array}{l}3,997 \\
4,008\end{array}$ & $\begin{array}{l}\mathrm{s} \\
\mathrm{s}\end{array}$ \\
\hline $7 \mathrm{~S} / 3 \mathrm{E}-23 \mathrm{D} 1$ & $\begin{array}{l}05-26-53 \\
11-23-53 \\
04-20-54 \\
08-04-60 \\
08-12-69\end{array}$ & $3,974.58$ & $\begin{array}{l}23.10 \\
22.40 \\
22.30 \\
29.84 \\
35.38\end{array}$ & $\begin{array}{l}3,951 \\
3,952 \\
3,952 \\
3,945 \\
3,939\end{array}$ & $\begin{array}{l}\mathrm{s} \\
\mathrm{s} \\
\mathrm{s} \\
\mathrm{s} \\
\mathrm{s}\end{array}$ \\
\hline & $\begin{array}{l}08-06-73 \\
07-17-86\end{array}$ & & $\begin{array}{l}29.13 \\
45.07\end{array}$ & $\begin{array}{l}3,945 \\
3,930\end{array}$ & $\begin{array}{l}\mathrm{s} \\
\mathrm{s}\end{array}$ \\
\hline
\end{tabular}


SUPPLEMENTAL DATA B: Water levels--Continued

\begin{tabular}{|c|c|c|c|c|c|}
\hline $\begin{array}{l}\text { We11 } \\
\text { number }\end{array}$ & $\begin{array}{c}\text { Measurement } \\
\text { date }\end{array}$ & $\begin{array}{l}\text { Land- } \\
\text { surface } \\
\text { altitude } \\
\text { (feet) }\end{array}$ & $\begin{array}{c}\text { Depth } \\
\text { to water } \\
\text { (feet below } \\
\text { land surface) }\end{array}$ & $\begin{array}{l}\text { Water- } \\
\text { table } \\
\text { altitude } \\
\text { (feet) }\end{array}$ & $\begin{array}{c}\text { Site } \\
\text { status }\end{array}$ \\
\hline $7 S / 3 E-23 Q 1$ & $\begin{array}{l}04-08-86 \\
07-18-86\end{array}$ & 4,080 & $\begin{array}{l}45.70 \\
46.71\end{array}$ & $\begin{array}{l}4,034 \\
4,033\end{array}$ & $\begin{array}{l}r \\
s\end{array}$ \\
\hline $7 S / 3 E-24 C 1$ & $\begin{array}{l}08-11-69 \\
08-03-73 \\
08-01-86\end{array}$ & 4,320 & $\begin{array}{r}45.78 \\
75.80 \\
126.45\end{array}$ & $\begin{array}{l}4,274 \\
4,244 \\
4,194\end{array}$ & $\begin{array}{l}\mathrm{s} \\
\mathrm{s} \\
\mathrm{s}\end{array}$ \\
\hline $7 \mathrm{~S} / 3 \mathrm{E}-25 \mathrm{D} 1$ & $\begin{array}{l}01-14-86 \\
04-09-86 \\
07-15-86\end{array}$ & 4,240 & $\begin{array}{l}30.85 \\
29.50 \\
28.03\end{array}$ & $\begin{array}{l}4,209 \\
4,210 \\
4,212\end{array}$ & $\begin{array}{l}s \\
s \\
s\end{array}$ \\
\hline $7 \mathrm{~S} / 3 \mathrm{E}-26 \mathrm{~A} 1$ & $\begin{array}{l}08-30-73 \\
04-09-86 \\
07-30-86\end{array}$ & $\begin{array}{l}4,170 \\
4,170\end{array}$ & $\begin{array}{r}191.30 \\
79.95 \\
84.43\end{array}$ & $\begin{array}{l}3,979 \\
4,090 \\
4,086\end{array}$ & $\begin{array}{l}r \\
s \\
s\end{array}$ \\
\hline $7 \mathrm{~S} / 3 \mathrm{E}-29 \mathrm{Q} 1$ & $\begin{array}{l}01-15-86 \\
07-14-86\end{array}$ & 3,890 & $\begin{array}{l}33.52 \\
32.85\end{array}$ & $\begin{array}{l}3,856 \\
3,857\end{array}$ & $\begin{array}{l}\mathrm{p} \\
\mathrm{s}\end{array}$ \\
\hline $7 \mathrm{~S} / 3 \mathrm{E}-30 \mathrm{P} 1$ & $\begin{array}{l}04-07-86 \\
07-14-86\end{array}$ & 3,680 & $\begin{array}{l}1.50 \\
4.15\end{array}$ & $\begin{array}{l}3,678 \\
3,676\end{array}$ & $\begin{array}{l}s \\
s\end{array}$ \\
\hline $7 \mathrm{~S} / 3 \mathrm{E}-31 \mathrm{~L} 2$ & $\begin{array}{l}11-23-85 \\
04-07-86 \\
07-15-86\end{array}$ & 3,790 & $\begin{array}{l}15.54 \\
13.43 \\
15.35\end{array}$ & $\begin{array}{l}3,774 \\
3,777 \\
3,775\end{array}$ & $\begin{array}{l}r \\
r \\
r\end{array}$ \\
\hline $7 \mathrm{~S} / 3 \mathrm{E}-31 \mathrm{~N} 1$ & $\begin{array}{l}01-06-86 \\
04-07-86 \\
07-14-86\end{array}$ & 3,900 & $\begin{array}{l}44.30 \\
40.56 \\
40.16\end{array}$ & $\begin{array}{l}3,856 \\
3,859 \\
3,860\end{array}$ & $\begin{array}{l}r \\
s \\
s\end{array}$ \\
\hline $7 \mathrm{~S} / 3 \mathrm{E}-31 \mathrm{Q} 1$ & $\begin{array}{l}06-11-70 \\
06-13-72 \\
07-19-72 \\
08-24-72 \\
09-28-72\end{array}$ & 3,840 & $\begin{array}{l}41.00 \\
58.18 \\
58.40 \\
63.25 \\
47.94\end{array}$ & $\begin{array}{l}3,799 \\
3,782 \\
3,782 \\
3,777 \\
3,792\end{array}$ & $\begin{array}{l}\mathrm{s} \\
\mathrm{r} \\
\mathrm{r} \\
\mathrm{r} \\
\mathrm{s}\end{array}$ \\
\hline & $\begin{array}{l}10-16-72 \\
11-30-72 \\
01-03-73 \\
02-06-73 \\
03-09-73\end{array}$ & & $\begin{array}{l}51.71 \\
49.06 \\
45.22 \\
49.56 \\
43.45\end{array}$ & $\begin{array}{l}3,788 \\
3,791 \\
3,795 \\
3,790 \\
3,797\end{array}$ & $\begin{array}{l}\mathrm{s} \\
\mathrm{s} \\
\mathrm{s} \\
\mathrm{s} \\
\mathrm{s}\end{array}$ \\
\hline
\end{tabular}


SUPPLEMENTAL DATA B: Water levels--Continued

\begin{tabular}{|c|c|c|c|c|c|}
\hline $\begin{array}{l}\text { Well } \\
\text { number }\end{array}$ & $\begin{array}{c}\text { Measurement } \\
\text { date }\end{array}$ & $\begin{array}{l}\text { Land- } \\
\text { surface } \\
\text { a1titude } \\
(\text { feet) }\end{array}$ & $\begin{array}{c}\text { Depth } \\
\text { to water } \\
\text { (feet below } \\
\text { land surface) }\end{array}$ & $\begin{array}{l}\text { Water- } \\
\text { table } \\
\text { a1titude } \\
\text { (feet) }\end{array}$ & $\begin{array}{l}\text { Site } \\
\text { status }\end{array}$ \\
\hline $7 S / 3 E-31 Q 1$ & $\begin{array}{l}04-18-73 \\
05-31-73 \\
07-24-73 \\
08-29-73 \\
09-14-73\end{array}$ & 3,840 & $\begin{array}{l}40.14 \\
57.24 \\
61.68 \\
61.54 \\
49.09\end{array}$ & $\begin{array}{l}3,800 \\
3,783 \\
3,778 \\
3,778 \\
3,791\end{array}$ & $\begin{array}{l}\mathrm{s} \\
\mathrm{r} \\
\mathrm{p} \\
\mathrm{p} \\
\mathrm{s}\end{array}$ \\
\hline & $\begin{array}{l}10-12-73 \\
11-16-73 \\
12-24-73 \\
01-25-74 \\
02-22-74\end{array}$ & & $\begin{array}{l}47.48 \\
55.80 \\
45.00 \\
45.86 \\
49.28\end{array}$ & $\begin{array}{l}3,793 \\
3,784 \\
3,795 \\
3,794 \\
3,791\end{array}$ & $\begin{array}{l}\mathrm{s} \\
\mathrm{s} \\
\mathrm{s} \\
\mathrm{s} \\
\mathrm{s}\end{array}$ \\
\hline & $\begin{array}{l}03-26-74 \\
04-18-74 \\
05-09-74 \\
06-05-74 \\
07-05-74\end{array}$ & & $\begin{array}{l}56.90 \\
66.70 \\
56.80 \\
48.30 \\
68.60\end{array}$ & $\begin{array}{l}3,783 \\
3,773 \\
3,783 \\
3,792 \\
3,771\end{array}$ & $\begin{array}{l}\mathrm{p} \\
\mathrm{p} \\
\mathrm{p} \\
\mathrm{r} \\
\mathrm{r}\end{array}$ \\
\hline & $\begin{array}{l}08-06-74 \\
09-05-74 \\
10-03-74 \\
11-11-74 \\
12-27-74\end{array}$ & & $\begin{array}{l}48.00 \\
46.40 \\
57.50 \\
45.14 \\
47.63\end{array}$ & $\begin{array}{l}3,792 \\
3,794 \\
3,782 \\
3,795 \\
3,792\end{array}$ & $\begin{array}{l}p \\
p \\
p \\
s \\
s\end{array}$ \\
\hline & $\begin{array}{l}01-28-75 \\
02-26-75 \\
04-10-75 \\
05-07-75 \\
06-02-75\end{array}$ & & $\begin{array}{l}57.85 \\
47.97 \\
44.67 \\
43.55 \\
61.78\end{array}$ & $\begin{array}{l}3,782 \\
3,792 \\
3,795 \\
3,796 \\
3,778\end{array}$ & $\begin{array}{l}\mathrm{s} \\
\mathrm{s} \\
\mathrm{s} \\
\mathrm{s} \\
\mathrm{r}\end{array}$ \\
\hline & $\begin{array}{l}06-26-75 \\
07-24-75 \\
08-28-75 \\
09-29-75 \\
01-22-76\end{array}$ & & $\begin{array}{l}60.75 \\
58.52 \\
67.17 \\
54.26 \\
47.96\end{array}$ & $\begin{array}{l}3,779 \\
3,781 \\
3,773 \\
3,786 \\
3,792\end{array}$ & $\begin{array}{l}r \\
r \\
r \\
r \\
r\end{array}$ \\
\hline & $\begin{array}{l}05-28-76 \\
09-02-76 \\
11-18-76 \\
12-16-76 \\
02-04-77\end{array}$ & & $\begin{array}{l}65.44 \\
70.62 \\
48.50 \\
45.52 \\
64.52\end{array}$ & $\begin{array}{l}3,775 \\
3,769 \\
3,792 \\
3,794 \\
3,775\end{array}$ & $\begin{array}{l}\mathrm{r} \\
\mathrm{r} \\
\mathrm{s} \\
\mathrm{s} \\
\mathrm{r}\end{array}$ \\
\hline
\end{tabular}


SUPPLEMENTAL DATA B: Water levels--Continued

\begin{tabular}{|c|c|c|c|c|c|}
\hline $\begin{array}{l}\text { Well } \\
\text { number }\end{array}$ & $\begin{array}{c}\text { Measurement } \\
\text { date }\end{array}$ & $\begin{array}{l}\text { Land- } \\
\text { surface } \\
\text { altitude } \\
\text { (feet) }\end{array}$ & $\begin{array}{c}\text { Depth } \\
\text { to water } \\
\text { (feet below } \\
\text { land surface) }\end{array}$ & $\begin{array}{l}\text { Water- } \\
\text { table } \\
\text { altitude } \\
\text { (feet) }\end{array}$ & $\begin{array}{l}\text { Site } \\
\text { status }\end{array}$ \\
\hline \multirow[t]{7}{*}{$7 S / 3 E-31 Q 1$} & $\begin{array}{l}03-24-77 \\
04-21-77 \\
06-08-77 \\
07-21-77 \\
08-24-77\end{array}$ & 3,840 & $\begin{array}{l}74.50 \\
45.39 \\
51.18 \\
43.95 \\
76.85\end{array}$ & $\begin{array}{l}3,766 \\
3,795 \\
3,789 \\
3,796 \\
3,763\end{array}$ & $\begin{array}{l}r \\
s \\
r \\
s \\
r\end{array}$ \\
\hline & $\begin{array}{l}09-22-77 \\
11-21-77 \\
12-19-77 \\
01-25-78 \\
02-16-78\end{array}$ & & $\begin{array}{l}66.95 \\
45.58 \\
47.57 \\
45.37 \\
50.90\end{array}$ & $\begin{array}{l}3,773 \\
3,794 \\
3,792 \\
3,795 \\
3,789\end{array}$ & $\begin{array}{l}r \\
s \\
s \\
s \\
r\end{array}$ \\
\hline & $\begin{array}{l}03-08-78 \\
07-19-78 \\
10-10-78 \\
01-11-79 \\
02-07-79\end{array}$ & & $\begin{array}{l}45.65 \\
45.55 \\
40.47 \\
46.68 \\
38.66\end{array}$ & $\begin{array}{l}3,794 \\
3,794 \\
3,800 \\
3,793 \\
3,801\end{array}$ & $\begin{array}{l}\mathrm{s} \\
\mathrm{r} \\
\mathrm{s} \\
\mathrm{r} \\
\mathrm{s}\end{array}$ \\
\hline & $\begin{array}{l}03-30-79 \\
04-25-79 \\
05-14-79 \\
06-28-79 \\
08-13-79\end{array}$ & & $\begin{array}{l}34.47 \\
32.63 \\
32.32 \\
33.17 \\
35.03\end{array}$ & $\begin{array}{l}3,806 \\
3,807 \\
3,808 \\
3,807 \\
3,805\end{array}$ & $\begin{array}{l}\mathrm{s} \\
\mathrm{s} \\
\mathrm{s} \\
\mathrm{s} \\
\mathrm{s}\end{array}$ \\
\hline & $\begin{array}{l}09-14-79 \\
10-16-79 \\
11-15-79 \\
12-20-79 \\
01-23-80\end{array}$ & & $\begin{array}{l}36.04 \\
37.07 \\
37.29 \\
39.78 \\
36.03\end{array}$ & $\begin{array}{l}3,804 \\
3,803 \\
3,803 \\
3,800 \\
3,804\end{array}$ & $\begin{array}{l}s \\
s \\
s \\
p \\
s\end{array}$ \\
\hline & $\begin{array}{l}02-28-80 \\
03-31-80 \\
05-14-80 \\
07-02-80 \\
07-30-80\end{array}$ & & $\begin{array}{l}56.95 \\
28.77 \\
42.72 \\
40.35 \\
34.36\end{array}$ & $\begin{array}{l}3,783 \\
3,811 \\
3,797 \\
3,800 \\
3,806\end{array}$ & $\begin{array}{l}r \\
s \\
r \\
r \\
s\end{array}$ \\
\hline & $\begin{array}{l}09-03-80 \\
10-10-80 \\
11-07-80 \\
12-11-80 \\
01-27-81\end{array}$ & & $\begin{array}{l}34.38 \\
40.10 \\
36.80 \\
35.28 \\
37.52\end{array}$ & $\begin{array}{l}3,806 \\
3,800 \\
3,803 \\
3,805 \\
3,802\end{array}$ & $\begin{array}{l}s \\
r \\
s \\
s \\
s\end{array}$ \\
\hline
\end{tabular}


SUPPLEMENTAL DATA B: Water levels--Continued

\begin{tabular}{|c|c|c|c|c|c|}
\hline $\begin{array}{l}\text { Well } \\
\text { number }\end{array}$ & $\begin{array}{c}\text { Measurement } \\
\text { date }\end{array}$ & $\begin{array}{l}\text { Land- } \\
\text { surface } \\
\text { altitude } \\
\text { (feet) }\end{array}$ & $\begin{array}{c}\text { Depth } \\
\text { to water } \\
\text { (feet below } \\
\text { land surface) }\end{array}$ & $\begin{array}{l}\text { Water- } \\
\text { table } \\
\text { altitude } \\
\text { (feet) }\end{array}$ & $\begin{array}{l}\text { Site } \\
\text { status }\end{array}$ \\
\hline \multirow[t]{5}{*}{$7 \mathrm{~S} / 3 \mathrm{E}-31 \mathrm{Q} 1$} & $\begin{array}{l}02-17-81 \\
03-10-81 \\
04-07-81 \\
06-04-81 \\
07-08-81\end{array}$ & 3,840 & $\begin{array}{l}56.23 \\
37.80 \\
50.69 \\
33.92 \\
38.62\end{array}$ & $\begin{array}{l}3,784 \\
3,802 \\
3,789 \\
3,806 \\
3,801\end{array}$ & $\begin{array}{l}r \\
r \\
r \\
s \\
r\end{array}$ \\
\hline & $\begin{array}{l}08-06-81 \\
09-15-81 \\
10-15-81 \\
12-28-81 \\
03-03-82\end{array}$ & & $\begin{array}{l}36.47 \\
44.68 \\
55.86 \\
41.73 \\
33.55\end{array}$ & $\begin{array}{l}3,804 \\
3,795 \\
3,784 \\
3,798 \\
3,806\end{array}$ & $\begin{array}{l}\mathrm{s} \\
\mathrm{r} \\
\mathrm{r} \\
\mathrm{r} \\
\mathrm{s}\end{array}$ \\
\hline & $\begin{array}{l}04-12-82 \\
06-29-82 \\
08-24-82 \\
12-02-82 \\
03-24-83\end{array}$ & & $\begin{array}{l}30.98 \\
33.20 \\
35.91 \\
34.70 \\
29.03\end{array}$ & $\begin{array}{l}3,809 \\
3,807 \\
3,804 \\
3,806 \\
3,811\end{array}$ & $\begin{array}{l}\mathbf{s} \\
\mathbf{s} \\
\mathbf{s} \\
\mathrm{s} \\
\mathrm{s}\end{array}$ \\
\hline & $\begin{array}{l}06-28-83 \\
10-05-83 \\
12-09-83 \\
03-15-84 \\
06-26-84\end{array}$ & & $\begin{array}{l}44.71 \\
33.36 \\
32.18 \\
31.14 \\
34.00\end{array}$ & $\begin{array}{l}3,795 \\
3,807 \\
3,808 \\
3,809 \\
3,806\end{array}$ & $\begin{array}{l}\mathrm{p} \\
\mathrm{s} \\
\mathrm{r} \\
\mathrm{s} \\
\mathrm{s}\end{array}$ \\
\hline & $\begin{array}{l}10-02-84 \\
01-07-86 \\
07-14-86\end{array}$ & & $\begin{array}{l}36.38 \\
31.35 \\
37.86\end{array}$ & $\begin{array}{l}3,804 \\
3,809 \\
3,802\end{array}$ & $\begin{array}{l}r \\
s \\
s\end{array}$ \\
\hline $7 \mathrm{~S} / 3 \mathrm{E}-34 \mathrm{E} 1$ & $\begin{array}{l}04-19-46 \\
01-31-51 \\
03-08-51 \\
04-05-51 \\
05-08-51\end{array}$ & $3,876.51$ & $\begin{array}{l}39.40 \\
34.50 \\
34.70 \\
36.90 \\
36.20\end{array}$ & $\begin{array}{l}3,837 \\
3,842 \\
3,842 \\
3,840 \\
3,840\end{array}$ & $\begin{array}{l}\mathrm{s} \\
\mathrm{s} \\
\mathrm{s} \\
\mathrm{s} \\
\mathrm{s}\end{array}$ \\
\hline & $\begin{array}{l}06-13-51 \\
07-09-51 \\
07-31-51 \\
09-06-51 \\
10-03-51\end{array}$ & & $\begin{array}{l}37.90 \\
37.90 \\
37.00 \\
36.70 \\
36.30\end{array}$ & $\begin{array}{l}3,839 \\
3,839 \\
3,840 \\
3,840 \\
3,840\end{array}$ & $\begin{array}{l}\mathrm{s} \\
\mathrm{s} \\
\mathrm{s} \\
\mathrm{s} \\
\mathrm{s}\end{array}$ \\
\hline
\end{tabular}


SUPPLEMENTAL DATA B: Water levels--Continued

\begin{tabular}{|c|c|c|c|c|c|}
\hline $\begin{array}{c}\text { We11 } \\
\text { number }\end{array}$ & $\begin{array}{c}\text { Measurement } \\
\text { date }\end{array}$ & $\begin{array}{l}\text { Land- } \\
\text { surface } \\
\text { altitude } \\
(\text { feet) }\end{array}$ & $\begin{array}{c}\text { Depth } \\
\text { to water } \\
\text { (feet below } \\
\text { land surface) }\end{array}$ & $\begin{array}{l}\text { Water- } \\
\text { table } \\
\text { altitude } \\
\text { (feet) }\end{array}$ & $\begin{array}{l}\text { Site } \\
\text { status }\end{array}$ \\
\hline $7 \mathrm{~S} / 3 \mathrm{E}-34 \mathrm{E} 1$ & $\begin{array}{l}11-07-51 \\
11-15-51 \\
01-03-52 \\
11-24-53 \\
05-07-54\end{array}$ & $3,876.51$ & $\begin{array}{l}35.90 \\
37.30 \\
34.70 \\
37.60 \\
38.20\end{array}$ & $\begin{array}{l}3,841 \\
3,839 \\
3,842 \\
3,839 \\
3,838\end{array}$ & $\begin{array}{l}\mathrm{s} \\
\mathrm{s} \\
\mathrm{s} \\
\mathrm{s} \\
\mathrm{s}\end{array}$ \\
\hline & $\begin{array}{l}08-25-60 \\
10-30-69 \\
06-13-72 \\
07-19-72 \\
08-24-72\end{array}$ & & $\begin{array}{l}48.17 \\
58.32 \\
68.50 \\
70.41 \\
70.46\end{array}$ & $\begin{array}{l}3,828 \\
3,818 \\
3,808 \\
3,806 \\
3,806\end{array}$ & $\begin{array}{l}\mathrm{s} \\
\mathrm{s} \\
\mathrm{r} \\
\mathrm{r} \\
\mathrm{r}\end{array}$ \\
\hline & $\begin{array}{l}09-27-72 \\
10-16-72 \\
11-30-72 \\
01-03-73 \\
02-06-73\end{array}$ & & $\begin{array}{l}70.53 \\
69.75 \\
66.22 \\
65.51 \\
68.52\end{array}$ & $\begin{array}{l}3,806 \\
3,807 \\
3,810 \\
3,811 \\
3,808\end{array}$ & $\begin{array}{l}r \\
s \\
s \\
s \\
s\end{array}$ \\
\hline & $\begin{array}{l}03-09-73 \\
04-19-73 \\
05-31-73 \\
07-24-73 \\
08-29-73\end{array}$ & & $\begin{array}{l}64.85 \\
67.75 \\
66.84 \\
76.75 \\
70.55\end{array}$ & $\begin{array}{l}3,812 \\
3,809 \\
3,810 \\
3,800 \\
3,806\end{array}$ & $\begin{array}{l}\mathrm{s} \\
\mathrm{s} \\
\mathrm{s} \\
\mathrm{s} \\
\mathrm{s}\end{array}$ \\
\hline & $\begin{array}{l}09-14-73 \\
10-12-73 \\
11-16-73 \\
12-24-73 \\
01-25-74\end{array}$ & & $\begin{array}{l}70.98 \\
71.99 \\
72.61 \\
69.64 \\
68.30\end{array}$ & $\begin{array}{l}3,806 \\
3,805 \\
3,804 \\
3,807 \\
3,808\end{array}$ & $\begin{array}{l}\mathrm{s} \\
\mathrm{s} \\
\mathrm{s} \\
\mathrm{s} \\
\mathrm{s}\end{array}$ \\
\hline & $\begin{array}{l}02-22-74 \\
03-26-74 \\
04-18-74 \\
05-09-74 \\
06-05-74\end{array}$ & & $\begin{array}{l}69.38 \\
69.93 \\
68.75 \\
69.66 \\
71.32\end{array}$ & $\begin{array}{l}3,807 \\
3,807 \\
3,808 \\
3,807 \\
3,805\end{array}$ & $\begin{array}{l}\mathrm{s} \\
\mathrm{s} \\
\mathrm{p} \\
\mathrm{s} \\
\mathrm{s}\end{array}$ \\
\hline & $\begin{array}{l}07-05-74 \\
08-06-74 \\
09-05-74 \\
10-03-74 \\
11-11-74\end{array}$ & & $\begin{array}{l}72.00 \\
72.90 \\
71.55 \\
70.94 \\
71.49\end{array}$ & $\begin{array}{l}3,805 \\
3,804 \\
3,805 \\
3,806 \\
3,805\end{array}$ & $\begin{array}{l}r \\
p \\
r \\
p \\
p\end{array}$ \\
\hline
\end{tabular}


SUPPLEMENTAL DATA B: Water levels--Continued

\begin{tabular}{|c|c|c|c|c|c|}
\hline $\begin{array}{l}\text { Well } \\
\text { number }\end{array}$ & $\begin{array}{l}\text { Measurement } \\
\text { date }\end{array}$ & $\begin{array}{l}\text { Land- } \\
\text { surface } \\
\text { altitude } \\
\text { (feet) }\end{array}$ & $\begin{array}{c}\text { Depth } \\
\text { to water } \\
\text { (feet below } \\
\text { land surface) }\end{array}$ & $\begin{array}{l}\text { Water- } \\
\text { table } \\
\text { altitude } \\
\text { (feet) }\end{array}$ & $\begin{array}{l}\text { Site } \\
\text { status }\end{array}$ \\
\hline $7 \mathrm{~S} / 3 \mathrm{E}-34 \mathrm{E} 1$ & $\begin{array}{l}12-27-74 \\
01-28-75 \\
02-26-75 \\
04-10-75 \\
05-07-75\end{array}$ & $3,876.51$ & $\begin{array}{l}68.75 \\
68.26 \\
70.47 \\
69.72 \\
69.95\end{array}$ & $\begin{array}{l}3,808 \\
3,808 \\
3,806 \\
3,807 \\
3,807\end{array}$ & $\begin{array}{l}\mathrm{s} \\
\mathrm{s} \\
\mathrm{s} \\
\mathrm{s} \\
\mathrm{s}\end{array}$ \\
\hline & $\begin{array}{l}06-02-75 \\
06-26-75 \\
07-24-75 \\
08-28-75 \\
09-29-75\end{array}$ & & $\begin{array}{l}71.95 \\
72.58 \\
72.63 \\
73.00 \\
70.52\end{array}$ & $\begin{array}{l}3,805 \\
3,804 \\
3,804 \\
3,804 \\
3,806\end{array}$ & $\begin{array}{l}r \\
r \\
r \\
s \\
s\end{array}$ \\
\hline & $\begin{array}{l}11-05-75 \\
12-10-75 \\
01-22-76 \\
03-29-76 \\
05-27-76\end{array}$ & & $\begin{array}{l}70.71 \\
70.60 \\
68.90 \\
71.30 \\
71.24\end{array}$ & $\begin{array}{l}3,806 \\
3,806 \\
3,808 \\
3,805 \\
3,805\end{array}$ & $\begin{array}{l}r \\
s \\
s \\
s \\
s\end{array}$ \\
\hline & $\begin{array}{l}07-07-76 \\
08-04-76 \\
09-02-76 \\
10-12-76 \\
11-18-76\end{array}$ & & $\begin{array}{l}72.41 \\
72.88 \\
73.04 \\
72.27 \\
72.44\end{array}$ & $\begin{array}{l}3,804 \\
3,804 \\
3,803 \\
3,804 \\
3,804\end{array}$ & $\begin{array}{l}r \\
s \\
s \\
r \\
r\end{array}$ \\
\hline & $\begin{array}{l}12-16-76 \\
02-04-77 \\
03-24-77 \\
04-21-77 \\
06-08-77\end{array}$ & & $\begin{array}{l}71.68 \\
70.69 \\
69.69 \\
70.45 \\
70.30\end{array}$ & $\begin{array}{l}3,805 \\
3,806 \\
3,807 \\
3,806 \\
3,806\end{array}$ & $\begin{array}{l}r \\
s \\
s \\
s \\
s\end{array}$ \\
\hline & $\begin{array}{l}07-21-77 \\
08-24-77 \\
09-22-77 \\
11-21-77 \\
12-19-77\end{array}$ & & $\begin{array}{l}72.28 \\
71.61 \\
71.83 \\
71.28 \\
70.29\end{array}$ & $\begin{array}{l}3,804 \\
3,805 \\
3,805 \\
3,805 \\
3,806\end{array}$ & $\begin{array}{l}\mathrm{s} \\
\mathrm{s} \\
\mathrm{s} \\
\mathrm{s} \\
\mathrm{s}\end{array}$ \\
\hline & $\begin{array}{l}01-25-78 \\
02-16-78 \\
03-08-78 \\
07-19-78 \\
09-07-78\end{array}$ & & $\begin{array}{l}69.66 \\
64.57 \\
61.44 \\
71.30 \\
72.40\end{array}$ & $\begin{array}{l}3,807 \\
3,812 \\
3,815 \\
3,805 \\
3,804\end{array}$ & $\begin{array}{l}s \\
s \\
s \\
s \\
s\end{array}$ \\
\hline
\end{tabular}


SUPPLEMENTAL DATA B: Water levels--Continued

\begin{tabular}{|c|c|c|c|c|c|}
\hline $\begin{array}{l}\text { Well } \\
\text { number }\end{array}$ & $\begin{array}{c}\text { Measurement } \\
\text { date }\end{array}$ & $\begin{array}{l}\text { Land- } \\
\text { surface } \\
\text { altitude } \\
\text { (feet) }\end{array}$ & $\begin{array}{c}\text { Depth } \\
\text { to water } \\
\text { (feet below } \\
\text { land surface) }\end{array}$ & $\begin{array}{l}\text { Water- } \\
\text { table } \\
\text { altitude } \\
\text { (feet) }\end{array}$ & $\begin{array}{l}\text { Site } \\
\text { status }\end{array}$ \\
\hline $7 \mathrm{~S}-3 \mathrm{E}-34 \mathrm{E} 1$ & $\begin{array}{l}10-10-78 \\
01-11-79 \\
02-10-79 \\
03-30-79 \\
04-25-79\end{array}$ & $3,876.51$ & $\begin{array}{l}70.20 \\
68.59 \\
68.35 \\
67.93 \\
68.37\end{array}$ & $\begin{array}{l}3,806 \\
3,808 \\
3,808 \\
3,809 \\
3,808\end{array}$ & $\begin{array}{l}\mathrm{s} \\
\mathrm{s} \\
\mathrm{s} \\
\mathrm{s} \\
\mathrm{s}\end{array}$ \\
\hline & $\begin{array}{l}05-14-79 \\
06-28-79 \\
08-13-79 \\
09-14-79 \\
10-16-79\end{array}$ & & $\begin{array}{l}68.55 \\
67.64 \\
67.29 \\
67.08 \\
66.89\end{array}$ & $\begin{array}{l}3,808 \\
3,809 \\
3,809 \\
3,809 \\
3,810\end{array}$ & $\begin{array}{l}\mathrm{s} \\
\mathrm{s} \\
\mathrm{s} \\
\mathrm{s} \\
\mathrm{s}\end{array}$ \\
\hline & $\begin{array}{l}11-15-79 \\
12-20-79 \\
01-23-80 \\
02-28-80 \\
03-31-80\end{array}$ & & $\begin{array}{l}66.60 \\
66.22 \\
65.99 \\
65.51 \\
64.99\end{array}$ & $\begin{array}{l}3,810 \\
3,810 \\
3,811 \\
3,811 \\
3,812\end{array}$ & $\begin{array}{l}\mathrm{s} \\
\mathrm{s} \\
\mathrm{s} \\
\mathrm{s} \\
\mathrm{s}\end{array}$ \\
\hline & $\begin{array}{l}05-14-80 \\
07-02-80 \\
07-30-80 \\
09-03-80 \\
10-10-80\end{array}$ & & $\begin{array}{l}64.55 \\
67.35 \\
67.65 \\
66.97 \\
65.59\end{array}$ & $\begin{array}{l}3,812 \\
3,809 \\
3,809 \\
3,810 \\
3,811\end{array}$ & $\begin{array}{l}\mathrm{s} \\
\mathrm{s} \\
\mathrm{s} \\
\mathrm{s} \\
\mathrm{s}\end{array}$ \\
\hline & $\begin{array}{l}11-07-80 \\
12-11-80 \\
01-27-81 \\
02-17-81 \\
03-10-81\end{array}$ & & $\begin{array}{l}64.52 \\
63.76 \\
62.94 \\
62.58 \\
62.61\end{array}$ & $\begin{array}{l}3,812 \\
3,813 \\
3,814 \\
3,814 \\
3,814\end{array}$ & $\begin{array}{l}\mathrm{s} \\
\mathrm{s} \\
\mathrm{s} \\
\mathrm{s} \\
\mathrm{s}\end{array}$ \\
\hline & $\begin{array}{l}04-07-81 \\
06-04-81 \\
07-08-81 \\
08-06-81 \\
09-15-81\end{array}$ & & $\begin{array}{l}61.99 \\
64.23 \\
66.68 \\
67.68 \\
67.74\end{array}$ & $\begin{array}{l}3,815 \\
3,812 \\
3,810 \\
3,809 \\
3,812\end{array}$ & $\begin{array}{l}\mathrm{s} \\
\mathrm{s} \\
\mathrm{s} \\
\mathrm{s} \\
\mathrm{s}\end{array}$ \\
\hline & $\begin{array}{l}10-15-81 \\
12-28-81 \\
03-03-82 \\
04-12-82 \\
06-29-82\end{array}$ & & $\begin{array}{l}63.51 \\
61.92 \\
61.15 \\
60.83 \\
63.88\end{array}$ & $\begin{array}{l}3,813 \\
3,815 \\
3,815 \\
3,816 \\
3,813\end{array}$ & $\begin{array}{l}\mathrm{s} \\
\mathrm{s} \\
\mathrm{s} \\
\mathrm{s} \\
\mathrm{s}\end{array}$ \\
\hline
\end{tabular}


SUPPLEMENTAL DATA B: Water levels--Continued

\begin{tabular}{|c|c|c|c|c|c|}
\hline $\begin{array}{l}\text { We11 } \\
\text { number }\end{array}$ & $\begin{array}{c}\text { Measurement } \\
\text { date }\end{array}$ & $\begin{array}{l}\text { Land- } \\
\text { surface } \\
\text { altitude } \\
\text { (feet) }\end{array}$ & $\begin{array}{c}\text { Depth } \\
\text { to water } \\
\text { (feet below } \\
\text { land surface) }\end{array}$ & $\begin{array}{l}\text { Water- } \\
\text { table } \\
\text { altitude } \\
\text { (feet) }\end{array}$ & $\begin{array}{l}\text { Site } \\
\text { status }\end{array}$ \\
\hline $7 \mathrm{~S} / 3 \mathrm{E}-34 \mathrm{E} 1$ & $\begin{array}{l}08-24-82 \\
12-02-82 \\
06-28-83 \\
10-05-83 \\
12-09-83\end{array}$ & $3,876.51$ & $\begin{array}{l}62.98 \\
60.66 \\
61.35 \\
58.88 \\
57.50\end{array}$ & $\begin{array}{l}3,814 \\
3,816 \\
3,815 \\
3,818 \\
3,819\end{array}$ & $\begin{array}{l}\mathrm{s} \\
\mathrm{s} \\
\mathrm{s} \\
\mathrm{s} \\
\mathrm{s}\end{array}$ \\
\hline & $\begin{array}{l}03-15-84 \\
06-26-84 \\
10-02-84 \\
12-03-84 \\
03-15-85\end{array}$ & & $\begin{array}{l}57.64 \\
56.60 \\
55.83 \\
54.70 \\
53.73\end{array}$ & $\begin{array}{l}3,819 \\
3,820 \\
3,821 \\
3,822 \\
3,823\end{array}$ & $\begin{array}{l}\mathrm{s} \\
\mathrm{s} \\
\mathrm{s} \\
\mathrm{s} \\
\mathrm{s}\end{array}$ \\
\hline & $\begin{array}{l}06-05-85 \\
09-12-85 \\
06-13-86 \\
06-18-86 \\
06-29-86\end{array}$ & & $\begin{array}{l}56.74 \\
58.86 \\
56.02 \\
57.14 \\
58.04\end{array}$ & $\begin{array}{l}3,820 \\
3,818 \\
3,820 \\
3,819 \\
3,818\end{array}$ & $\begin{array}{l}\mathrm{s} \\
\mathrm{s} \\
\mathrm{s} \\
\mathrm{s} \\
\mathrm{s}\end{array}$ \\
\hline & $07-31-86$ & & 61.50 & 3,815 & $\mathbf{s}$ \\
\hline $7 \mathrm{~S} / 3 \mathrm{E}-36 \mathrm{~B} 1$ & $\begin{array}{l}01-14-86 \\
07-31-86\end{array}$ & 4,240 & $\begin{array}{r}98.50 \\
106.66\end{array}$ & $\begin{array}{l}4,142 \\
4,133\end{array}$ & $\begin{array}{l}\mathrm{s} \\
\mathrm{s}\end{array}$ \\
\hline $7 S / 3 E-36 E 3$ & $\begin{array}{l}01-14-86 \\
04-09-86 \\
07-15-86\end{array}$ & 4,060 & $\begin{array}{l}79.30 \\
78.51 \\
91.98\end{array}$ & $\begin{array}{l}3,981 \\
3,981 \\
3,968\end{array}$ & $\begin{array}{l}\mathrm{s} \\
\mathrm{s} \\
\mathrm{s}\end{array}$ \\
\hline $7 \mathrm{~S} / 3 \mathrm{E}-36 \mathrm{~F} 1$ & $01-14-86$ & 4,165 & 67.95 & 4,097 & $\mathbf{s}$ \\
\hline $7 \mathrm{~S} / 3 \mathrm{E}-36 \mathrm{Gl}$ & $\begin{array}{l}01-14-86 \\
04-09-86 \\
07-15-86 \\
07-30-86\end{array}$ & 4,170 & $\begin{array}{l}80.88 \\
81.84 \\
91.18 \\
84.94\end{array}$ & $\begin{array}{l}4,089 \\
4,088 \\
4,079 \\
4,085\end{array}$ & $\begin{array}{l}\mathrm{s} \\
\mathrm{s} \\
\mathrm{r} \\
\mathrm{s}\end{array}$ \\
\hline $7 \mathrm{~S} / 4 \mathrm{E}-19 \mathrm{~K} 1$ & $\begin{array}{l}08-07-69 \\
08-02-73 \\
08-01-86\end{array}$ & 4,550 & $\begin{array}{l}44.94 \\
61.70 \\
30.57\end{array}$ & $\begin{array}{l}4,505 \\
4,488 \\
4,519\end{array}$ & $\begin{array}{l}\mathrm{s} \\
\mathrm{s} \\
\mathrm{s}\end{array}$ \\
\hline
\end{tabular}


SUPPLEMENTAL DATA B: Water levels--Continued

\begin{tabular}{|c|c|c|c|c|c|}
\hline $\begin{array}{l}\text { We11 } \\
\text { number }\end{array}$ & $\begin{array}{c}\text { Measurement } \\
\text { date }\end{array}$ & $\begin{array}{l}\text { Land- } \\
\text { surface } \\
\text { a1titude } \\
\text { (feet) }\end{array}$ & $\begin{array}{c}\text { Depth } \\
\text { to water } \\
\text { (feet below } \\
\text { land surface) }\end{array}$ & $\begin{array}{l}\text { Water- } \\
\text { table } \\
\text { a1titude } \\
\text { (feet) }\end{array}$ & $\begin{array}{l}\text { Site } \\
\text { status }\end{array}$ \\
\hline $8 \mathrm{~S} / 2 \mathrm{E}-4 \mathrm{P} 1$ & $\begin{array}{l}11-22-85 \\
01-08-86 \\
04-07-86 \\
07-14-86\end{array}$ & 3,634 & $\begin{array}{l}88.14 \\
88.38 \\
89.21 \\
89.81\end{array}$ & $\begin{array}{l}3,546 \\
3,546 \\
3,545 \\
3,544\end{array}$ & $\begin{array}{l}r \\
s \\
s \\
s\end{array}$ \\
\hline $8 S / 2 E-5 B 1$ & $11-22-85$ & 3,460 & 53.40 & 3,407 & s \\
\hline $8 S / 2 E-5 G 1$ & $\begin{array}{l}01-09-86 \\
04-07-86 \\
07-31-86\end{array}$ & 3,475 & $\begin{array}{l}26.20 \\
26.42 \\
26.35\end{array}$ & $\begin{array}{l}3,449 \\
3,449 \\
3,449\end{array}$ & $\begin{array}{l}s \\
s \\
s\end{array}$ \\
\hline $8 \mathrm{~S} / 2 \mathrm{E}-5 \mathrm{~K} 1$ & $\begin{array}{l}01-10-86 \\
04-07-86 \\
07-17-86\end{array}$ & 3,540 & $\begin{array}{l}85.39 \\
85.58 \\
87.25\end{array}$ & $\begin{array}{l}3,454 \\
3,454 \\
3,453\end{array}$ & $\begin{array}{l}s \\
s \\
s\end{array}$ \\
\hline $8 S / 2 E-9 B 1$ & $\begin{array}{l}08-29-73 \\
11-21-85 \\
07-31-86\end{array}$ & 3,680 & $\begin{array}{l}68.50 \\
62.28 \\
66.68\end{array}$ & $\begin{array}{l}3,612 \\
3,618 \\
3,613\end{array}$ & $\begin{array}{l}s \\
s \\
s\end{array}$ \\
\hline $8 S / 3 E-1 P 1$ & $\begin{array}{l}01-23-86 \\
04-07-86 \\
07-15-86 \\
07-30-86\end{array}$ & 3,870 & $\begin{array}{l}60.09 \\
58.44 \\
69.63 \\
60.05\end{array}$ & $\begin{array}{l}3,810 \\
3,812 \\
3,800 \\
3,810\end{array}$ & $\begin{array}{l}\mathrm{s} \\
\mathrm{s} \\
\mathrm{p} \\
\mathrm{s}\end{array}$ \\
\hline $8 \mathrm{~S} / 3 \mathrm{E}-2 \mathrm{~A} 1$ & $\begin{array}{l}02-05-86 \\
06-15-86 \\
06-18-86 \\
06-29-86\end{array}$ & 3,905 & $\begin{array}{l}90.11 \\
87.75 \\
89.99 \\
90.60\end{array}$ & $\begin{array}{l}3,815 \\
3,817 \\
3,815 \\
3,814\end{array}$ & $\begin{array}{l}\mathrm{s} \\
\mathrm{s} \\
\mathrm{s} \\
\mathrm{s}\end{array}$ \\
\hline $8 \mathrm{~S} / 3 \mathrm{E}-2 \mathrm{D} 1$ & $\begin{array}{l}07-25-60 \\
10-30-69 \\
06-13-72 \\
07-19-72 \\
08-24-72\end{array}$ & 3,900 & $\begin{array}{l}44.08 \\
69.09 \\
69.15 \\
71.86 \\
69.39\end{array}$ & $\begin{array}{l}3,856 \\
3,831 \\
3,831 \\
3,828 \\
3,831\end{array}$ & $\begin{array}{l}\mathrm{s} \\
\mathrm{s} \\
\mathrm{s} \\
\mathrm{s} \\
\mathrm{s}\end{array}$ \\
\hline & $\begin{array}{l}09-27-72 \\
10-16-72 \\
11-30-72 \\
01-03-73 \\
02-06-73\end{array}$ & & $\begin{array}{l}69.18 \\
68.79 \\
65.88 \\
70.39 \\
65.82\end{array}$ & $\begin{array}{l}3,831 \\
3,831 \\
3,834 \\
3,830 \\
3,834\end{array}$ & $\begin{array}{l}\mathrm{s} \\
\mathrm{s} \\
\mathrm{s} \\
\mathrm{s} \\
\mathrm{s}\end{array}$ \\
\hline
\end{tabular}


SUPPLEMENTAL DATA B: Water levels--Continued

\begin{tabular}{|c|c|c|c|c|c|}
\hline $\begin{array}{l}\text { We11 } \\
\text { number }\end{array}$ & $\begin{array}{c}\text { Measurement } \\
\text { date }\end{array}$ & $\begin{array}{l}\text { Land- } \\
\text { surface } \\
\text { altitude } \\
\text { (feet) }\end{array}$ & $\begin{array}{c}\text { Depth } \\
\text { to water } \\
\text { (feet below } \\
\text { land surface) }\end{array}$ & $\begin{array}{l}\text { Water- } \\
\text { table } \\
\text { altitude } \\
\text { (feet) }\end{array}$ & $\begin{array}{l}\text { Site } \\
\text { status }\end{array}$ \\
\hline $8 \mathrm{~S} / 3 \mathrm{E}-2 \mathrm{D} 1$ & $\begin{array}{l}03-09-73 \\
04-19-73 \\
05-31-73 \\
07-29-73 \\
08-29-73\end{array}$ & 3,900 & $\begin{array}{l}66.89 \\
64.96 \\
69.91 \\
69.20 \\
72.80\end{array}$ & $\begin{array}{l}3,836 \\
3,835 \\
3,830 \\
3,831 \\
3,827\end{array}$ & $\begin{array}{l}\mathrm{s} \\
\mathrm{s} \\
\mathrm{s} \\
\mathrm{s} \\
\mathrm{s}\end{array}$ \\
\hline & $\begin{array}{l}09-14-73 \\
10-12-73 \\
11-16-73 \\
12-29-73 \\
01-25-74\end{array}$ & & $\begin{array}{l}70.82 \\
77.00 \\
78.99 \\
67.18 \\
66.09\end{array}$ & $\begin{array}{l}3,829 \\
3,823 \\
3,821 \\
3,833 \\
3,834\end{array}$ & $\begin{array}{l}s \\
s \\
s \\
s \\
s\end{array}$ \\
\hline & $\begin{array}{l}02-22-74 \\
03-26-74 \\
04-18-74 \\
05-09-74 \\
06-05-74\end{array}$ & & $\begin{array}{l}66.52 \\
66.85 \\
66.78 \\
67.61 \\
69.00\end{array}$ & $\begin{array}{l}3,833 \\
3,833 \\
3,833 \\
3,832 \\
3,831\end{array}$ & $\begin{array}{l}\mathrm{s} \\
\mathrm{s} \\
\mathrm{s} \\
\mathrm{s} \\
\mathrm{s}\end{array}$ \\
\hline & $\begin{array}{l}07-05-74 \\
08-06-74 \\
09-05-74 \\
10-03-74 \\
11-11-74\end{array}$ & & $\begin{array}{l}69.79 \\
69.61 \\
70.28 \\
69.76 \\
68.96\end{array}$ & $\begin{array}{l}3,830 \\
3,830 \\
3,830 \\
3,830 \\
3,831\end{array}$ & $\begin{array}{l}\mathrm{s} \\
\mathrm{s} \\
\mathrm{s} \\
\mathrm{s} \\
\mathrm{s}\end{array}$ \\
\hline & $\begin{array}{l}12-27-74 \\
01-28-75 \\
02-26-75 \\
04-10-75 \\
05-07-75\end{array}$ & & $\begin{array}{l}67.27 \\
66.92 \\
67.44 \\
67.21 \\
67.70\end{array}$ & $\begin{array}{l}3,833 \\
3,833 \\
3,833 \\
3,833 \\
3,832\end{array}$ & $\begin{array}{l}\mathrm{s} \\
\mathrm{s} \\
\mathrm{s} \\
\mathrm{s} \\
\mathrm{s}\end{array}$ \\
\hline & $\begin{array}{l}06-02-75 \\
06-26-75 \\
07-24-75 \\
08-28-75 \\
09-29-75\end{array}$ & & $\begin{array}{l}69.42 \\
70.48 \\
70.63 \\
70.84 \\
69.83\end{array}$ & $\begin{array}{l}3,831 \\
3,830 \\
3,829 \\
3,829 \\
3,830\end{array}$ & $\begin{array}{l}\mathrm{s} \\
\mathrm{s} \\
\mathrm{s} \\
\mathrm{s} \\
\mathrm{s}\end{array}$ \\
\hline & $\begin{array}{l}11-05-75 \\
12-10-75 \\
01-22-76 \\
03-29-76 \\
05-27-76\end{array}$ & & $\begin{array}{l}68.75 \\
68.58 \\
67.58 \\
68.64 \\
69.78\end{array}$ & $\begin{array}{l}3,831 \\
3,831 \\
3,832 \\
3,831 \\
3,830\end{array}$ & $\begin{array}{l}\mathrm{s} \\
\mathrm{s} \\
\mathrm{s} \\
\mathrm{s} \\
\mathrm{s}\end{array}$ \\
\hline
\end{tabular}


SUPPLEMENTAL DATA B: Water levels--Continued

\begin{tabular}{|c|c|c|c|c|c|}
\hline $\begin{array}{l}\text { We11 } \\
\text { number }\end{array}$ & $\begin{array}{c}\text { Measurement } \\
\text { date }\end{array}$ & $\begin{array}{l}\text { Land- } \\
\text { surface } \\
\text { altitude } \\
\text { (feet) }\end{array}$ & $\begin{array}{c}\text { Depth } \\
\text { to water } \\
\text { (feet below } \\
\text { land surface) }\end{array}$ & $\begin{array}{l}\text { Water- } \\
\text { table } \\
\text { altitude } \\
\text { (feet) }\end{array}$ & $\begin{array}{l}\text { Site } \\
\text { status }\end{array}$ \\
\hline $8 \mathrm{~S} / 3 \mathrm{E}-2 \mathrm{D} 1$ & $\begin{array}{l}07-07-76 \\
08-04-76 \\
09-02-76 \\
10-12-76 \\
11-18-76\end{array}$ & 3,900 & $\begin{array}{l}70.81 \\
71.51 \\
71.72 \\
70.40 \\
70.18\end{array}$ & $\begin{array}{l}3,830 \\
3,828 \\
3,828 \\
3,830 \\
3,830\end{array}$ & $\begin{array}{l}\mathrm{s} \\
\mathrm{s} \\
\mathrm{s} \\
\mathrm{s} \\
\mathrm{s}\end{array}$ \\
\hline & $\begin{array}{l}12-16-76 \\
02-04-77 \\
03-24-77 \\
04-21-77 \\
06-08-77\end{array}$ & & $\begin{array}{l}69.53 \\
69.02 \\
68.64 \\
69.93 \\
71.40\end{array}$ & $\begin{array}{l}3,830 \\
3,831 \\
3,831 \\
3,830 \\
3,829\end{array}$ & $\begin{array}{l}\mathbf{s} \\
\mathbf{s} \\
\mathbf{s} \\
\mathbf{s} \\
\mathbf{s}\end{array}$ \\
\hline & $\begin{array}{l}07-21-77 \\
08-24-77 \\
09-22-77 \\
11-21-77 \\
12-19-77\end{array}$ & & $\begin{array}{l}72.90 \\
72.47 \\
73.20 \\
71.70 \\
71.04\end{array}$ & $\begin{array}{l}3,827 \\
3,828 \\
3,827 \\
3,828 \\
3,829\end{array}$ & $\begin{array}{l}\mathbf{s} \\
\mathbf{s} \\
\mathrm{s} \\
\mathrm{s} \\
\mathrm{s}\end{array}$ \\
\hline & $\begin{array}{l}01-25-78 \\
02-16-78 \\
03-08-78 \\
07-19-78 \\
09-07-78\end{array}$ & & $\begin{array}{l}70.26 \\
67.41 \\
64.93 \\
72.00 \\
71.99\end{array}$ & $\begin{array}{l}3,830 \\
3,833 \\
3,835 \\
3,828 \\
3,828\end{array}$ & $\begin{array}{l}\mathrm{s} \\
\mathrm{s} \\
\mathrm{s} \\
\mathrm{s} \\
\mathrm{s}\end{array}$ \\
\hline & $\begin{array}{l}10-10-78 \\
01-11-79 \\
02-10-79 \\
03-30-79 \\
04-25-79\end{array}$ & & $\begin{array}{l}70.79 \\
68.99 \\
68.73 \\
68.36 \\
68.82\end{array}$ & $\begin{array}{l}3,829 \\
3,831 \\
3,831 \\
3,832 \\
3,831\end{array}$ & $\begin{array}{l}\mathrm{s} \\
\mathrm{s} \\
\mathrm{s} \\
\mathrm{s} \\
\mathrm{s}\end{array}$ \\
\hline & $\begin{array}{l}05-14-79 \\
06-28-79 \\
08-13-79 \\
09-14-79 \\
10-16-79\end{array}$ & & $\begin{array}{l}69.13 \\
69.29 \\
69.03 \\
69.13 \\
69.08\end{array}$ & $\begin{array}{l}3,831 \\
3,831 \\
3,831 \\
3,831 \\
3,831\end{array}$ & $\begin{array}{l}\mathrm{s} \\
\mathrm{s} \\
\mathrm{s} \\
\mathrm{s} \\
\mathrm{s}\end{array}$ \\
\hline & $\begin{array}{l}11-15-79 \\
12-20-79 \\
01-23-80 \\
02-28-80 \\
03-31-80\end{array}$ & & $\begin{array}{l}68.41 \\
67.99 \\
67.67 \\
67.18 \\
66.80\end{array}$ & $\begin{array}{l}3,832 \\
3,832 \\
3,832 \\
3,833 \\
3,833\end{array}$ & $\begin{array}{l}\mathbf{s} \\
\mathrm{s} \\
\mathrm{s} \\
\mathrm{s} \\
\mathrm{s}\end{array}$ \\
\hline
\end{tabular}


SUPPLEMENTAL DATA B: Water levels--Continued

\begin{tabular}{|c|c|c|c|c|c|}
\hline $\begin{array}{l}\text { Well } \\
\text { number }\end{array}$ & $\begin{array}{c}\text { Measurement } \\
\text { date }\end{array}$ & $\begin{array}{l}\text { Land- } \\
\text { surface } \\
\text { altitude } \\
\text { (feet) }\end{array}$ & $\begin{array}{c}\text { Depth } \\
\text { to water } \\
\text { (feet below } \\
\text { land surface) }\end{array}$ & $\begin{array}{l}\text { Water- } \\
\text { table } \\
\text { altitude } \\
\text { (feet) }\end{array}$ & $\begin{array}{l}\text { Site } \\
\text { status }\end{array}$ \\
\hline \multirow[t]{4}{*}{$8 S / 3 E-2 D 1$} & $\begin{array}{l}05-14-80 \\
07-02-80 \\
11-07-80 \\
12-11-80 \\
01-27-81\end{array}$ & 3,900 & $\begin{array}{l}73.78 \\
74.65 \\
73.90 \\
69.34 \\
68.14\end{array}$ & $\begin{array}{l}3,826 \\
3,825 \\
3,826 \\
3,831 \\
3,832\end{array}$ & $\begin{array}{l}r \\
r \\
r \\
s \\
s\end{array}$ \\
\hline & $\begin{array}{l}02-17-81 \\
03-10-81 \\
04-07-81 \\
06-04-81 \\
09-15-81\end{array}$ & & $\begin{array}{l}68.09 \\
67.44 \\
66.94 \\
70.92 \\
73.70\end{array}$ & $\begin{array}{l}3,832 \\
3,833 \\
3,833 \\
3,829 \\
3,826\end{array}$ & $\begin{array}{l}s \\
s \\
s \\
s \\
r\end{array}$ \\
\hline & $\begin{array}{l}10-15-81 \\
12-28-81 \\
03-03-82 \\
04-12-82 \\
06-29-82\end{array}$ & & $\begin{array}{l}73.72 \\
68.27 \\
67.26 \\
66.84 \\
73.90\end{array}$ & $\begin{array}{l}3,826 \\
3,832 \\
3,833 \\
3,833 \\
3,826\end{array}$ & $\begin{array}{l}r \\
s \\
s \\
s \\
r\end{array}$ \\
\hline & $\begin{array}{l}08-24-82 \\
12-02-82 \\
03-24-83 \\
10-05-83 \\
12-09-83 \\
06-26-84\end{array}$ & & $\begin{array}{l}74.68 \\
68.08 \\
74.29 \\
75.17 \\
66.75 \\
74.15\end{array}$ & $\begin{array}{l}3,825 \\
3,832 \\
3,826 \\
3,825 \\
3,833 \\
3,826\end{array}$ & $\begin{array}{l}r \\
s \\
r \\
r \\
s \\
r\end{array}$ \\
\hline $8 \mathrm{~S} / 3 \mathrm{E}-2 \mathrm{E} 1$ & $\begin{array}{l}12-06-50 \\
01-31-51 \\
03-08-51 \\
04-05-41 \\
05-08-51\end{array}$ & 3,892 & $\begin{array}{l}32.10 \\
32.50 \\
35.80 \\
33.90 \\
34.40\end{array}$ & $\begin{array}{l}3,860 \\
3,860 \\
3,856 \\
3,858 \\
3,858\end{array}$ & $\begin{array}{l}\mathrm{s} \\
\mathrm{s} \\
\mathrm{s} \\
\mathrm{s} \\
\mathrm{s}\end{array}$ \\
\hline & $\begin{array}{l}06-13-51 \\
07-09-51 \\
07-31-51 \\
09-06-51 \\
10-03-51\end{array}$ & & $\begin{array}{l}36.30 \\
34.20 \\
34.20 \\
34.20 \\
34.10\end{array}$ & $\begin{array}{l}3,856 \\
3,858 \\
3,858 \\
3,858 \\
3,858\end{array}$ & $\begin{array}{l}\mathrm{s} \\
\mathrm{s} \\
\mathrm{s} \\
\mathrm{s} \\
\mathrm{s}\end{array}$ \\
\hline & $\begin{array}{l}11-07-51 \\
11-15-51 \\
01-03-52 \\
02-04-52 \\
03-04-52\end{array}$ & & $\begin{array}{l}34.00 \\
33.90 \\
32.20 \\
33.00 \\
34.80\end{array}$ & $\begin{array}{l}3,858 \\
3,858 \\
3,860 \\
3,859 \\
3,857\end{array}$ & $\begin{array}{l}\mathrm{s} \\
\mathrm{s} \\
\mathrm{s} \\
\mathrm{s} \\
\mathrm{s}\end{array}$ \\
\hline
\end{tabular}


SUPPLEMENTAL DATA B: Water levels--Continued

\begin{tabular}{|c|c|c|c|c|c|}
\hline $\begin{array}{l}\text { Well } \\
\text { number }\end{array}$ & $\begin{array}{c}\text { Measurement } \\
\text { date }\end{array}$ & $\begin{array}{l}\text { Land- } \\
\text { surface } \\
\text { altitude } \\
(\text { feet) }\end{array}$ & $\begin{array}{c}\text { Depth } \\
\text { to water } \\
\text { (feet below } \\
\text { land surface) }\end{array}$ & $\begin{array}{l}\text { Water- } \\
\text { table } \\
\text { altitude } \\
\text { (feet) }\end{array}$ & $\begin{array}{l}\text { Site } \\
\text { status }\end{array}$ \\
\hline \multirow[t]{4}{*}{$8 \mathrm{~S} / 3 \mathrm{E}-2 \mathrm{E} 1$} & $\begin{array}{l}04-14-52 \\
05-13-52 \\
06-10-52 \\
07-08-52 \\
07-30-52\end{array}$ & 3,892 & $\begin{array}{l}32.70 \\
35.50 \\
34.00 \\
34.40 \\
36.00\end{array}$ & $\begin{array}{l}3,859 \\
3,856 \\
3,858 \\
3,858 \\
3,856\end{array}$ & $\begin{array}{l}\mathrm{s} \\
\mathrm{s} \\
\mathrm{s} \\
\mathrm{s} \\
\mathrm{s}\end{array}$ \\
\hline & $\begin{array}{l}08-25-52 \\
10-21-52 \\
01-16-53 \\
02-27-53 \\
03-27-53\end{array}$ & & $\begin{array}{l}35.50 \\
35.40 \\
33.40 \\
33.50 \\
33.10\end{array}$ & $\begin{array}{l}3,856 \\
3,857 \\
3,859 \\
3,858 \\
3,859\end{array}$ & $\begin{array}{l}\mathrm{s} \\
\mathrm{s} \\
\mathrm{s} \\
\mathrm{s} \\
\mathrm{s}\end{array}$ \\
\hline & $\begin{array}{l}05-27-53 \\
07-03-53 \\
08-10-53 \\
09-01-53 \\
10-08-53\end{array}$ & & $\begin{array}{l}33.90 \\
34.30 \\
34.80 \\
35.50 \\
35.50\end{array}$ & $\begin{array}{l}3,858 \\
3,858 \\
3,857 \\
3,856 \\
3,856\end{array}$ & $\begin{array}{l}\mathbf{s} \\
\mathrm{s} \\
\mathrm{s} \\
\mathrm{s} \\
\mathrm{s}\end{array}$ \\
\hline & $\begin{array}{l}11-23-53 \\
01-06-54 \\
02-04-54 \\
04-01-54 \\
08-25-60 \\
10-30-69\end{array}$ & & $\begin{array}{l}34.40 \\
34.50 \\
34.50 \\
34.00 \\
43.09 \\
42.31\end{array}$ & $\begin{array}{l}3,858 \\
3,858 \\
3,858 \\
3,858 \\
3,849 \\
3,850\end{array}$ & $\begin{array}{l}\mathrm{s} \\
\mathrm{s} \\
\mathrm{s} \\
\mathrm{s} \\
\mathrm{p} \\
\mathrm{s}\end{array}$ \\
\hline $8 \mathrm{~S} / 3 \mathrm{E}-2 \mathrm{~K} 1$ & $\begin{array}{l}06-13-72 \\
07-19-72 \\
08-24-72 \\
09-27-72 \\
10-16-72\end{array}$ & 3,870 & $\begin{array}{l}45.89 \\
47.70 \\
48.60 \\
47.75 \\
45.45\end{array}$ & $\begin{array}{l}3,824 \\
3,822 \\
3,821 \\
3,822 \\
3,825\end{array}$ & $\begin{array}{l}\mathrm{s} \\
\mathrm{s} \\
\mathrm{s} \\
\mathrm{s} \\
\mathrm{s}\end{array}$ \\
\hline & $\begin{array}{l}11-30-72 \\
01-03-73 \\
02-06-73 \\
03-16-73 \\
04-19-73\end{array}$ & & $\begin{array}{l}39.65 \\
39.97 \\
39.70 \\
36.20 \\
36.65\end{array}$ & $\begin{array}{l}3,830 \\
3,830 \\
3,830 \\
3,834 \\
3,833\end{array}$ & $\begin{array}{l}\mathrm{s} \\
\mathrm{s} \\
\mathrm{s} \\
\mathrm{s} \\
\mathrm{s}\end{array}$ \\
\hline & $\begin{array}{l}05-31-73 \\
07-24-73 \\
08-29-73 \\
09-14-73 \\
10-12-73\end{array}$ & & $\begin{array}{l}42.10 \\
45.63 \\
49.50 \\
50.67 \\
50.09\end{array}$ & $\begin{array}{l}3,828 \\
3,824 \\
3,820 \\
3,819 \\
3,820\end{array}$ & $\begin{array}{l}\mathbf{s} \\
\mathbf{s} \\
\mathrm{s} \\
\mathrm{s} \\
\mathrm{s}\end{array}$ \\
\hline
\end{tabular}


SUPPLEMENTAL DATA B: Water levels--Continued

\begin{tabular}{|c|c|c|c|c|c|}
\hline $\begin{array}{l}\text { Well } \\
\text { number }\end{array}$ & $\begin{array}{c}\text { Measurement } \\
\text { date }\end{array}$ & $\begin{array}{l}\text { Land- } \\
\text { surface } \\
\text { altitude } \\
\text { (feet) }\end{array}$ & $\begin{array}{c}\text { Depth } \\
\text { to water } \\
\text { (feet below } \\
\text { land surface) }\end{array}$ & $\begin{array}{l}\text { Water- } \\
\text { table } \\
\text { altitude } \\
\text { (feet) }\end{array}$ & $\begin{array}{l}\text { Site } \\
\text { status }\end{array}$ \\
\hline $8 S / 3 E-2 K 1$ & $\begin{array}{l}11-16-73 \\
12-24-73 \\
01-25-74 \\
02-22-74 \\
03-26-74\end{array}$ & 3,870 & $\begin{array}{l}46.56 \\
43.16 \\
40.84 \\
40.74 \\
40.16\end{array}$ & $\begin{array}{l}3,823 \\
3,827 \\
3,829 \\
3,829 \\
3,830\end{array}$ & $\begin{array}{l}\mathrm{s} \\
\mathrm{s} \\
\mathrm{s} \\
\mathrm{s} \\
\mathrm{s}\end{array}$ \\
\hline & $\begin{array}{l}04-18-74 \\
05-09-74 \\
06-05-74 \\
07-05-74 \\
08-06-74\end{array}$ & & $\begin{array}{l}41.41 \\
42.86 \\
46.14 \\
50.06 \\
52.51\end{array}$ & $\begin{array}{l}3,829 \\
3,827 \\
3,824 \\
3,820 \\
3,817\end{array}$ & $\begin{array}{l}\mathrm{s} \\
\mathrm{s} \\
\mathrm{s} \\
\mathrm{s} \\
\mathrm{s}\end{array}$ \\
\hline & $\begin{array}{l}09-05-74 \\
10-03-74 \\
11-11-74 \\
12-27-74 \\
01-28-75\end{array}$ & & $\begin{array}{l}54.66 \\
54.76 \\
49.18 \\
45.30 \\
44.17\end{array}$ & $\begin{array}{l}3,815 \\
3,815 \\
3,821 \\
3,825 \\
3,826\end{array}$ & $\begin{array}{l}\mathrm{s} \\
\mathrm{s} \\
\mathrm{s} \\
\mathrm{s} \\
\mathrm{s}\end{array}$ \\
\hline & $\begin{array}{l}02-26-75 \\
04-10-75 \\
05-07-75 \\
06-02-75 \\
06-26-75\end{array}$ & & $\begin{array}{l}43.35 \\
43.30 \\
44.31 \\
46.98 \\
51.22\end{array}$ & $\begin{array}{l}3,827 \\
3,827 \\
3,826 \\
3,823 \\
3,819\end{array}$ & $\begin{array}{l}\mathbf{s} \\
\mathbf{s} \\
\mathrm{s} \\
\mathrm{s} \\
\mathrm{s}\end{array}$ \\
\hline & $\begin{array}{l}07-24-75 \\
08-28-75 \\
09-29-75 \\
11-05-75 \\
12-10-75\end{array}$ & & $\begin{array}{l}53.56 \\
54.91 \\
51.28 \\
48.67 \\
48.08\end{array}$ & $\begin{array}{l}3,816 \\
3,815 \\
3,819 \\
3,821 \\
3,822\end{array}$ & $\begin{array}{l}\mathrm{s} \\
\mathrm{s} \\
\mathrm{s} \\
\mathrm{s} \\
\mathrm{s}\end{array}$ \\
\hline & $\begin{array}{l}01-22-76 \\
03-29-76 \\
05-28-76 \\
07-07-76 \\
08-04-76\end{array}$ & & $\begin{array}{l}47.26 \\
47.05 \\
52.03 \\
54.40 \\
55.98\end{array}$ & $\begin{array}{l}3,823 \\
3,823 \\
3,818 \\
3,816 \\
3,814\end{array}$ & $\begin{array}{l}\mathrm{s} \\
\mathrm{s} \\
\mathrm{s} \\
\mathrm{s} \\
\mathrm{s}\end{array}$ \\
\hline & $\begin{array}{l}09-02-76 \\
10-12-76 \\
11-18-76 \\
12-16-76 \\
02-04-77\end{array}$ & & $\begin{array}{l}57.32 \\
52.07 \\
50.51 \\
49.40 \\
48.30\end{array}$ & $\begin{array}{l}3,813 \\
3,818 \\
3,819 \\
3,821 \\
3,822\end{array}$ & $\begin{array}{l}\mathrm{s} \\
\mathrm{s} \\
\mathrm{s} \\
\mathrm{s} \\
\mathrm{s}\end{array}$ \\
\hline
\end{tabular}


SUPPLEMENTAL DATA B: Water levels--Continued

\begin{tabular}{|c|c|c|c|c|c|}
\hline $\begin{array}{l}\text { We11 } \\
\text { number }\end{array}$ & $\begin{array}{c}\text { Measurement } \\
\text { date }\end{array}$ & $\begin{array}{l}\text { Land- } \\
\text { surface } \\
\text { altitude } \\
\text { (feet) }\end{array}$ & $\begin{array}{c}\text { Depth } \\
\text { to water } \\
\text { (feet below } \\
\text { land surface) }\end{array}$ & $\begin{array}{l}\text { Water- } \\
\text { table } \\
\text { altitude } \\
\text { (feet) }\end{array}$ & $\begin{array}{l}\text { Site } \\
\text { status }\end{array}$ \\
\hline $8 \mathrm{~S} / 3 \mathrm{E}-2 \mathrm{~K} 1$ & $\begin{array}{l}03-24-77 \\
04-21-77 \\
06-08-77 \\
07-21-77 \\
08-24-77\end{array}$ & 3,870 & $\begin{array}{l}48.44 \\
53.14 \\
52.12 \\
56.61 \\
56.53\end{array}$ & $\begin{array}{l}3,822 \\
3,817 \\
3,818 \\
3,813 \\
3,813\end{array}$ & $\begin{array}{l}\mathrm{s} \\
\mathrm{s} \\
\mathrm{s} \\
\mathrm{s} \\
\mathrm{s}\end{array}$ \\
\hline & $\begin{array}{l}09-22-77 \\
11-21-77 \\
12-19-77 \\
01-25-78 \\
02-16-78\end{array}$ & & $\begin{array}{l}54.78 \\
52.13 \\
50.84 \\
49.38 \\
49.07\end{array}$ & $\begin{array}{l}3,815 \\
3,818 \\
3,819 \\
3,821 \\
3,821\end{array}$ & $\begin{array}{l}\mathbf{s} \\
\mathbf{s} \\
\mathrm{s} \\
\mathrm{s} \\
\mathrm{s}\end{array}$ \\
\hline & $\begin{array}{l}03-08-78 \\
07-19-78 \\
09-07-78 \\
10-10-78 \\
01-11-79\end{array}$ & & $\begin{array}{l}46.14 \\
53.20 \\
52.50 \\
50.74 \\
48.34\end{array}$ & $\begin{array}{l}3,824 \\
3,817 \\
3,818 \\
3,819 \\
3,822\end{array}$ & $\begin{array}{l}\mathbf{s} \\
\mathrm{s} \\
\mathrm{s} \\
\mathrm{s} \\
\mathrm{s}\end{array}$ \\
\hline & $\begin{array}{l}02-07-79 \\
03-30-79 \\
04-25-79 \\
05-14-79 \\
06-28-79\end{array}$ & & $\begin{array}{l}47.98 \\
49.54 \\
51.70 \\
52.31 \\
54.65\end{array}$ & $\begin{array}{l}3,822 \\
3,820 \\
3,818 \\
3,818 \\
3,815\end{array}$ & $\begin{array}{l}\mathbf{s} \\
\mathbf{s} \\
\mathrm{s} \\
\mathrm{s} \\
\mathrm{s}\end{array}$ \\
\hline & $\begin{array}{l}08-13-79 \\
09-14-79 \\
10-16-79 \\
11-15-79 \\
12-20-79\end{array}$ & & $\begin{array}{l}58.86 \\
55.76 \\
53.41 \\
50.73 \\
48.95\end{array}$ & $\begin{array}{l}3,813 \\
3,814 \\
3,817 \\
3,819 \\
3,821\end{array}$ & $\begin{array}{l}s \\
s \\
s \\
s\end{array}$ \\
\hline & $\begin{array}{l}01-23-80 \\
02-28-80 \\
03-31-80 \\
05-14-80 \\
07-02-80\end{array}$ & & $\begin{array}{l}48.76 \\
47.40 \\
46.66 \\
47.80 \\
53.96\end{array}$ & $\begin{array}{l}3,821 \\
3,823 \\
3,823 \\
3,822 \\
3,816\end{array}$ & $\begin{array}{l}\mathrm{s} \\
\mathrm{s} \\
\mathrm{s} \\
\mathrm{s} \\
\mathrm{s}\end{array}$ \\
\hline & $\begin{array}{l}07-30-80 \\
11-07-80 \\
12-11-80 \\
01-27-81 \\
02-17-81\end{array}$ & & $\begin{array}{l}55.94 \\
54.34 \\
51.22 \\
50.46 \\
49.59\end{array}$ & $\begin{array}{l}3,814 \\
3,816 \\
3,819 \\
3,820 \\
3,820\end{array}$ & $\begin{array}{l}\mathbf{s} \\
\mathrm{s} \\
\mathrm{s} \\
\mathrm{s} \\
\mathrm{s}\end{array}$ \\
\hline
\end{tabular}


SUPPLEMENTAL DATA B: Water levels--Continued

\begin{tabular}{|c|c|c|c|c|c|}
\hline $\begin{array}{l}\text { We11 } \\
\text { number }\end{array}$ & $\begin{array}{l}\text { Measurement } \\
\text { date }\end{array}$ & $\begin{array}{l}\text { Land- } \\
\text { surface } \\
\text { altitude } \\
(\text { feet })\end{array}$ & $\begin{array}{c}\text { Depth } \\
\text { to water } \\
\text { (feet below } \\
\text { land surface) }\end{array}$ & $\begin{array}{l}\text { Water- } \\
\text { table } \\
\text { altitude } \\
\text { (feet) }\end{array}$ & $\begin{array}{l}\text { Site } \\
\text { status }\end{array}$ \\
\hline $8 \mathrm{~S} / 3 \mathrm{E}-2 \mathrm{~K} 1$ & $\begin{array}{l}03-10-81 \\
04-07-81 \\
06-04-81 \\
07-08-81 \\
08-06-81\end{array}$ & 3,870 & $\begin{array}{l}48.84 \\
49.81 \\
53.31 \\
55.79 \\
58.18\end{array}$ & $\begin{array}{l}3,821 \\
3,820 \\
3,817 \\
3,814 \\
3,812\end{array}$ & $\begin{array}{l}\mathrm{s} \\
\mathrm{s} \\
\mathrm{s} \\
\mathrm{s} \\
\mathrm{s}\end{array}$ \\
\hline & $\begin{array}{l}09-15-81 \\
10-15-81 \\
12-28-81 \\
03-03-82 \\
04-12-82\end{array}$ & & $\begin{array}{l}60.45 \\
57.36 \\
50.82 \\
49.41 \\
54.24\end{array}$ & $\begin{array}{l}3,810 \\
3,813 \\
3,819 \\
3,821 \\
3,816\end{array}$ & $\begin{array}{l}\mathrm{s} \\
\mathrm{s} \\
\mathrm{s} \\
\mathrm{s} \\
\mathrm{s}\end{array}$ \\
\hline & $\begin{array}{l}06-29-82 \\
08-24-82 \\
12-02-82 \\
03-24-83 \\
06-28-83\end{array}$ & & $\begin{array}{l}57.76 \\
59.18 \\
50.76 \\
48.31 \\
56.18\end{array}$ & $\begin{array}{l}3,812 \\
3,811 \\
3,819 \\
3,822 \\
3,814\end{array}$ & $\begin{array}{l}\mathrm{s} \\
\mathrm{s} \\
\mathrm{s} \\
\mathrm{s} \\
\mathrm{s}\end{array}$ \\
\hline & $\begin{array}{l}10-05-83 \\
12-09-83 \\
03-15-84 \\
06-26-84 \\
10-02-84\end{array}$ & & $\begin{array}{l}51.35 \\
48.03 \\
53.09 \\
49.67 \\
48.48\end{array}$ & $\begin{array}{l}3,819 \\
3,822 \\
3,817 \\
3,820 \\
3,822\end{array}$ & $\begin{array}{l}\mathrm{s} \\
\mathrm{s} \\
\mathrm{s} \\
\mathrm{s} \\
\mathrm{s}\end{array}$ \\
\hline & $\begin{array}{l}12-03-84 \\
03-15-85 \\
06-05-85 \\
09-12-85 \\
06-13-86\end{array}$ & & $\begin{array}{l}46.00 \\
45.68 \\
51.86 \\
56.32 \\
46.58\end{array}$ & $\begin{array}{l}3,824 \\
3,824 \\
3,818 \\
3,814 \\
3,823\end{array}$ & $\begin{array}{l}\mathrm{s} \\
\mathrm{s} \\
\mathrm{s} \\
\mathrm{s} \\
\mathrm{s}\end{array}$ \\
\hline & $\begin{array}{l}06-18-86 \\
06-29-86 \\
07-17-86\end{array}$ & & $\begin{array}{l}46.70 \\
47.33 \\
48.23\end{array}$ & $\begin{array}{l}3,823 \\
3,823 \\
3,822\end{array}$ & $\begin{array}{l}\mathrm{s} \\
\mathrm{s} \\
\mathrm{s}\end{array}$ \\
\hline $8 S / 3 E-5 Q 1$ & $07-30-86$ & 4,250 & 106.52 & 4,143 & $\mathrm{~s}$ \\
\hline $8 \mathrm{~S} / 3 \mathrm{E}-6 \mathrm{~B} 1$ & $\begin{array}{l}01-07-86 \\
07-14-86\end{array}$ & 3,910 & $\begin{array}{l}50.28 \\
52.00\end{array}$ & $\begin{array}{l}3,860 \\
3,858\end{array}$ & $\begin{array}{l}\mathrm{s} \\
\mathrm{s}\end{array}$ \\
\hline $8 \mathrm{~S} / 3 \mathrm{E}-6 \mathrm{~J} 1$ & $\begin{array}{l}01-06-86 \\
07-14-86\end{array}$ & 3,990 & $\begin{array}{l}61.72 \\
63.56\end{array}$ & $\begin{array}{l}3,928 \\
3,926\end{array}$ & $\begin{array}{l}\mathrm{s} \\
\mathrm{s}\end{array}$ \\
\hline
\end{tabular}


SUPPLEMENTAL DATA B: Water levels--Continued

\begin{tabular}{|c|c|c|c|c|c|}
\hline $\begin{array}{l}\text { Well } \\
\text { number }\end{array}$ & $\begin{array}{c}\text { Measurement } \\
\text { date }\end{array}$ & $\begin{array}{l}\text { Land- } \\
\text { surface } \\
\text { altitude } \\
\text { (feet) }\end{array}$ & $\begin{array}{c}\text { Depth } \\
\text { to water } \\
\text { (feet below } \\
\text { land surface) }\end{array}$ & $\begin{array}{l}\text { Water- } \\
\text { table } \\
\text { altitude } \\
\text { (feet) }\end{array}$ & $\begin{array}{l}\text { Site } \\
\text { status }\end{array}$ \\
\hline $8 \mathrm{~S} / 3 \mathrm{E}-10 \mathrm{~B} 1$ & $\begin{array}{l}07-19-73 \\
04-09-86 \\
07-15-86\end{array}$ & 4,070 & $\begin{array}{l}197.75 \\
191.32 \\
191.75\end{array}$ & $\begin{array}{l}3,872 \\
3,879 \\
3,878\end{array}$ & $\begin{array}{l}\mathrm{s} \\
\mathrm{s} \\
\mathrm{s}\end{array}$ \\
\hline $8 \mathrm{~S} / 3 \mathrm{E}-10 \mathrm{R} 2$ & $\begin{array}{l}01-14-86 \\
04-09-86 \\
07-16-86\end{array}$ & 4,020 & $\begin{array}{l}195.98 \\
195.56 \\
195.60\end{array}$ & $\begin{array}{l}3,824 \\
3,824 \\
3,824\end{array}$ & $\begin{array}{l}\mathrm{s} \\
\mathrm{s} \\
\mathrm{s}\end{array}$ \\
\hline $8 \mathrm{~S} / 3 \mathrm{E}-11 \mathrm{~A} 2$ & $\begin{array}{l}07-18-73 \\
07-31-86\end{array}$ & 3,870 & $\begin{array}{l}52.16 \\
40.77\end{array}$ & $\begin{array}{l}3,818 \\
3,829\end{array}$ & $\begin{array}{l}\mathrm{s} \\
\mathrm{s}\end{array}$ \\
\hline $8 \mathrm{~S} / 3 \mathrm{E}-11 \mathrm{C} 2$ & $\begin{array}{l}01-13-86 \\
07-15-86\end{array}$ & 3,925 & $\begin{array}{l}109.35 \\
109.81\end{array}$ & $\begin{array}{l}3,816 \\
3,816\end{array}$ & $\begin{array}{l}\mathrm{s} \\
\mathrm{s}\end{array}$ \\
\hline $8 \mathrm{~S} / 3 \mathrm{E}-11 \mathrm{E} 1$ & $\begin{array}{l}01-14-86 \\
07-17-86\end{array}$ & 3,950 & $\begin{array}{l}127.00 \\
128.49\end{array}$ & $\begin{array}{l}3,823 \\
3,822\end{array}$ & $\begin{array}{l}\mathrm{p} \\
\mathrm{s}\end{array}$ \\
\hline $8 \mathrm{~S} / 3 \mathrm{E}-11 \mathrm{~F} 1$ & $\begin{array}{l}01-14-86 \\
04-09-86 \\
07-30-86\end{array}$ & 3,930 & $\begin{array}{l}110.86 \\
100.19 \\
111.29\end{array}$ & $\begin{array}{l}3,819 \\
3,830 \\
3,819\end{array}$ & $\begin{array}{l}\mathbf{s} \\
\mathbf{s} \\
\mathbf{s}\end{array}$ \\
\hline $8 \mathrm{~S} / 3 \mathrm{E}-11 \mathrm{R} 1$ & $\begin{array}{l}07-17-73 \\
04-09-86 \\
07-30-86\end{array}$ & 3,920 & $\begin{array}{l}101.03 \\
101.94 \\
101.15\end{array}$ & $\begin{array}{l}3,819 \\
3,818 \\
3,819\end{array}$ & $\begin{array}{l}\mathrm{s} \\
\mathrm{s} \\
\mathrm{s}\end{array}$ \\
\hline $8 \mathrm{~S} / 3 \mathrm{E}-12 \mathrm{~K} 1$ & $\begin{array}{l}07-18-73 \\
07-31-86\end{array}$ & 3,880 & $\begin{array}{l}67.45 \\
77.08\end{array}$ & $\begin{array}{l}3,813 \\
3,803\end{array}$ & $\begin{array}{l}\mathrm{s} \\
\mathrm{s}\end{array}$ \\
\hline $8 S / 3 E-14 A 3$ & $\begin{array}{l}01-22-86 \\
07-16-86\end{array}$ & 4,100 & $\begin{array}{l}118.86 \\
124.24\end{array}$ & $\begin{array}{l}3,981 \\
3,976\end{array}$ & $\begin{array}{l}\mathrm{p} \\
\mathrm{p}\end{array}$ \\
\hline $8 \mathrm{~S} / 3 \mathrm{E}-14 \mathrm{E} 1$ & $\begin{array}{l}01-10-86 \\
07-16-86\end{array}$ & 4,060 & $\begin{array}{l}154.70 \\
174.53\end{array}$ & $\begin{array}{l}3,905 \\
3,885\end{array}$ & $\begin{array}{l}\mathbf{s} \\
\mathbf{s}\end{array}$ \\
\hline $8 \mathrm{~S} / 3 \mathrm{E}-14 \mathrm{Gl}$ & $08-01-86$ & 4,005 & 171.53 & 3,833 & $\mathbf{s}$ \\
\hline $8 \mathrm{~S} / 3 \mathrm{E}-15 \mathrm{~A} 2$ & $\begin{array}{l}01-13-86 \\
07-16-86\end{array}$ & 4,040 & $\begin{array}{l}228.20 \\
227.23\end{array}$ & $\begin{array}{l}3,812 \\
3,813\end{array}$ & $\begin{array}{l}\mathrm{s} \\
\mathrm{s}\end{array}$ \\
\hline
\end{tabular}


SUPPLEMENTAL DATA B: Water levels--Continued

\begin{tabular}{lccccc}
\hline $\begin{array}{c}\text { We11 } \\
\text { number }\end{array}$ & $\begin{array}{c}\text { Measurement } \\
\text { date }\end{array}$ & $\begin{array}{c}\text { Land- } \\
\text { surface } \\
\text { altitude } \\
\text { (feet) }\end{array}$ & $\begin{array}{c}\text { Depth } \\
\text { to water } \\
\text { feet below } \\
\text { land surface) }\end{array}$ & $\begin{array}{c}\text { Water- } \\
\text { table } \\
\text { altitude } \\
\text { (feet) }\end{array}$ & $\begin{array}{c}\text { Site } \\
\text { status }\end{array}$ \\
\hline 8S/3E-16D1 & $07-24-69$ & 4,330 & 159.77 & 4,170 & $\mathrm{~s}$ \\
& $07-31-73$ & & 130.15 & 4,200 & $\mathrm{~s}$ \\
& $04-09-86$ & & 74.19 & 4,256 & $\mathrm{r}$ \\
8S/4E-6F5 & $07-30-86$ & & 71.30 & 4,259 & $\mathrm{~s}$ \\
& $07-30-73$ & 4,000 & 185.46 & 3,815 & $\mathrm{~s}$ \\
& $04-07-86$ & & 190.52 & 3,809 & $\mathrm{~s}$ \\
8S/4E-7A1 & $07-31-86$ & & 190.58 & 3,809 & $\mathrm{~s}$ \\
& $07-03-73$ & 3,870 & 50.41 & 3,820 & $\mathrm{~s}$ \\
& $04-09-86$ & & 49.65 & 3,820 & $\mathrm{~s}$ \\
& $07-15-86$ & & 50.59 & 3,819 & $\mathrm{~s}$ \\
\hline
\end{tabular}




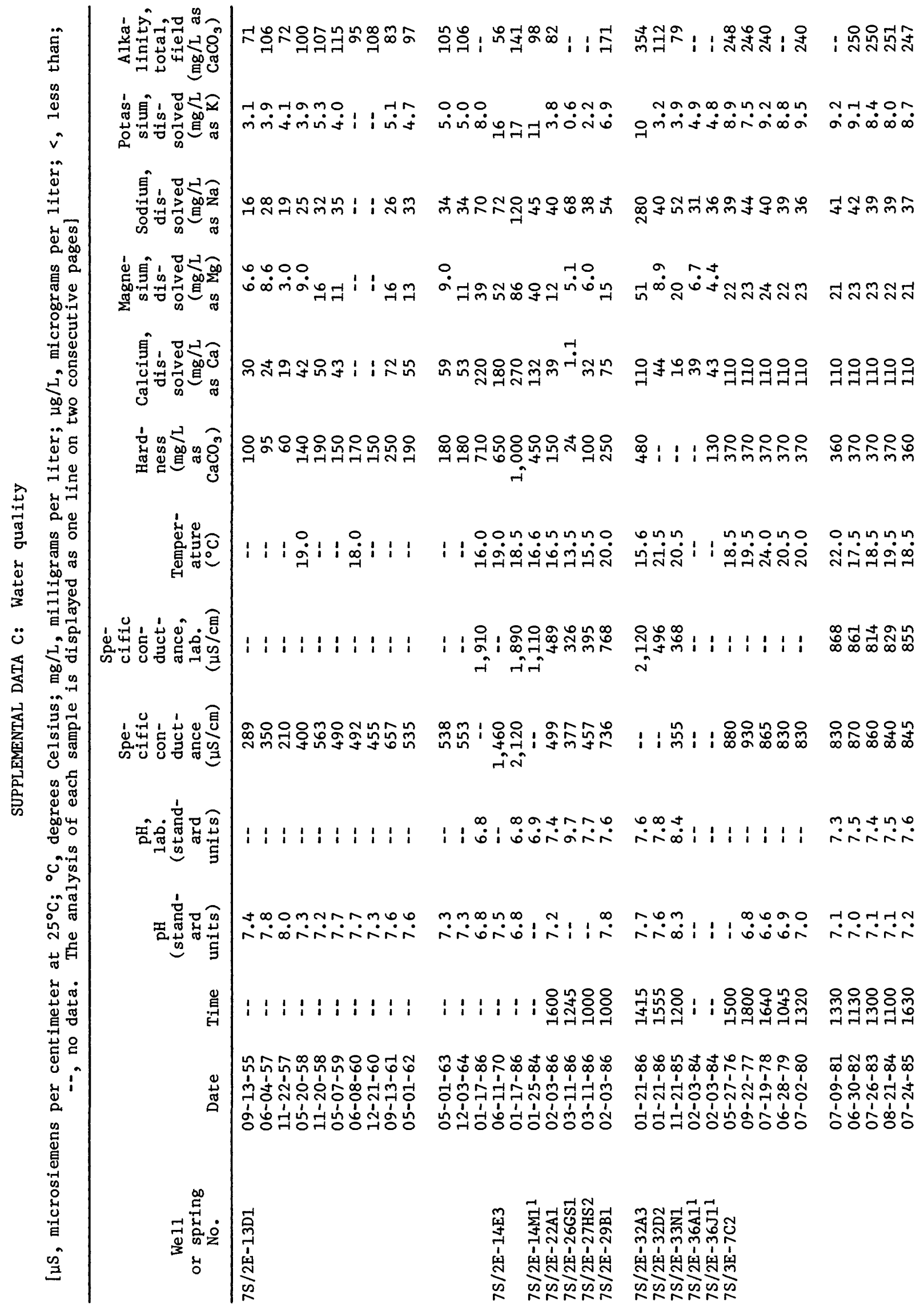




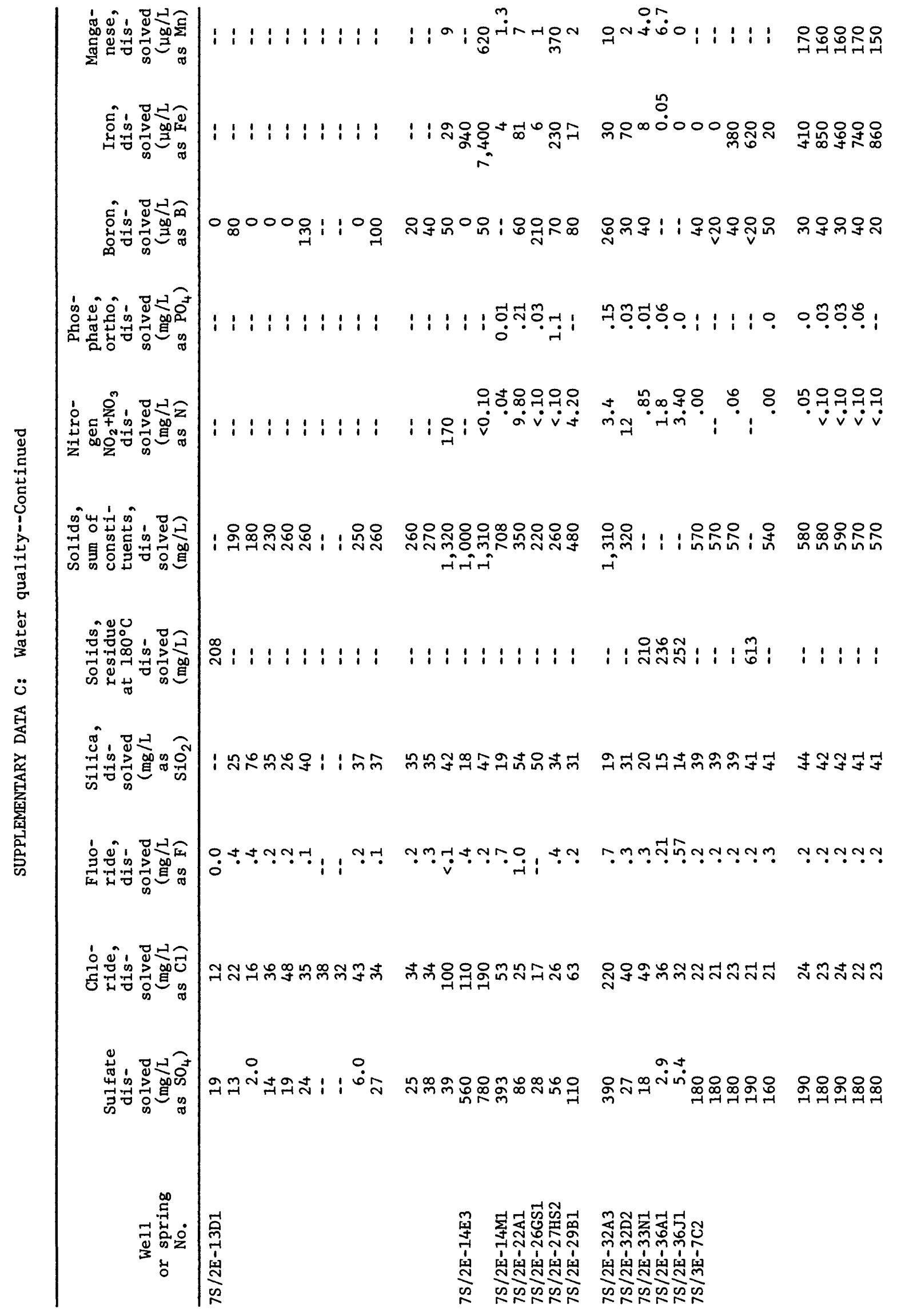




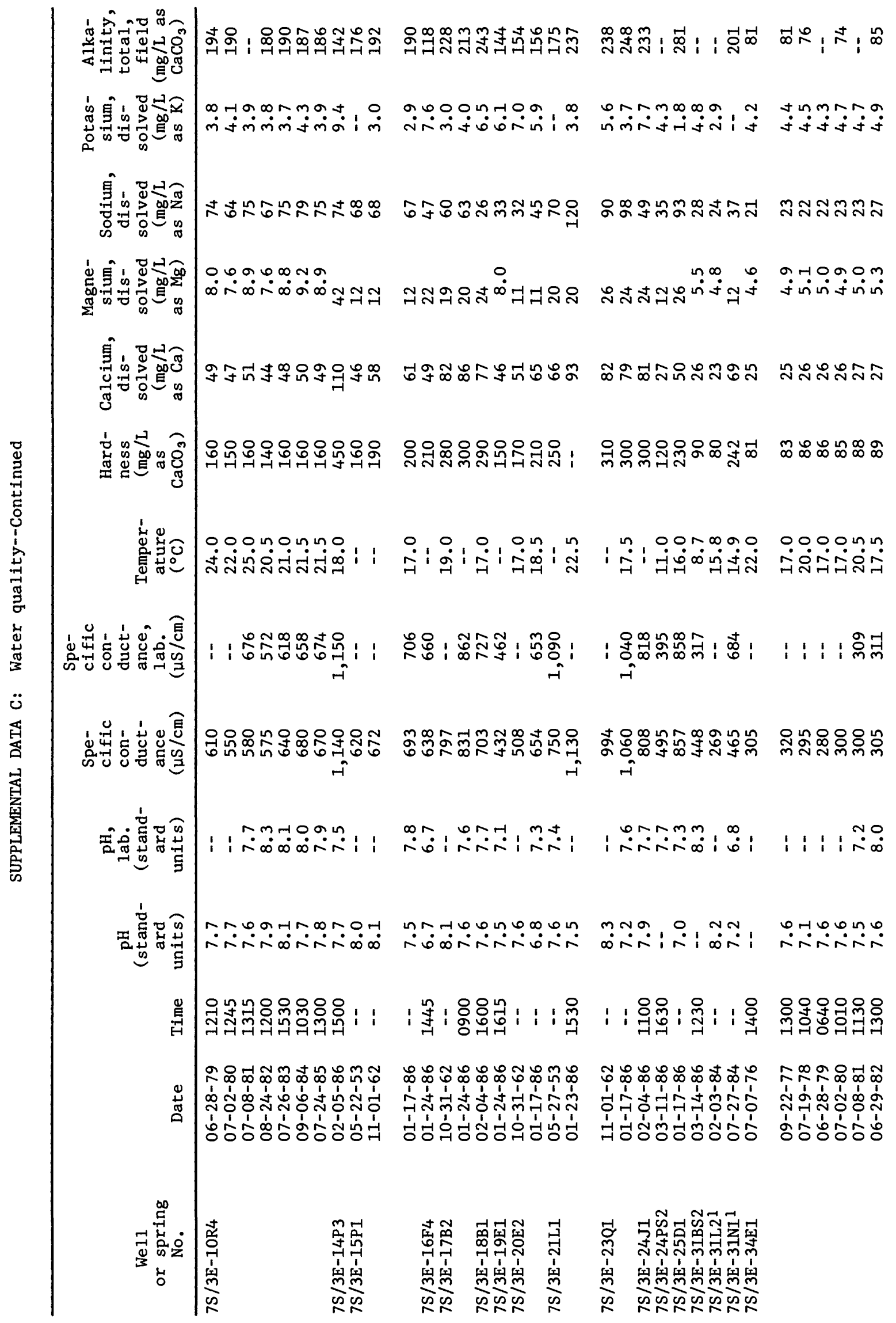




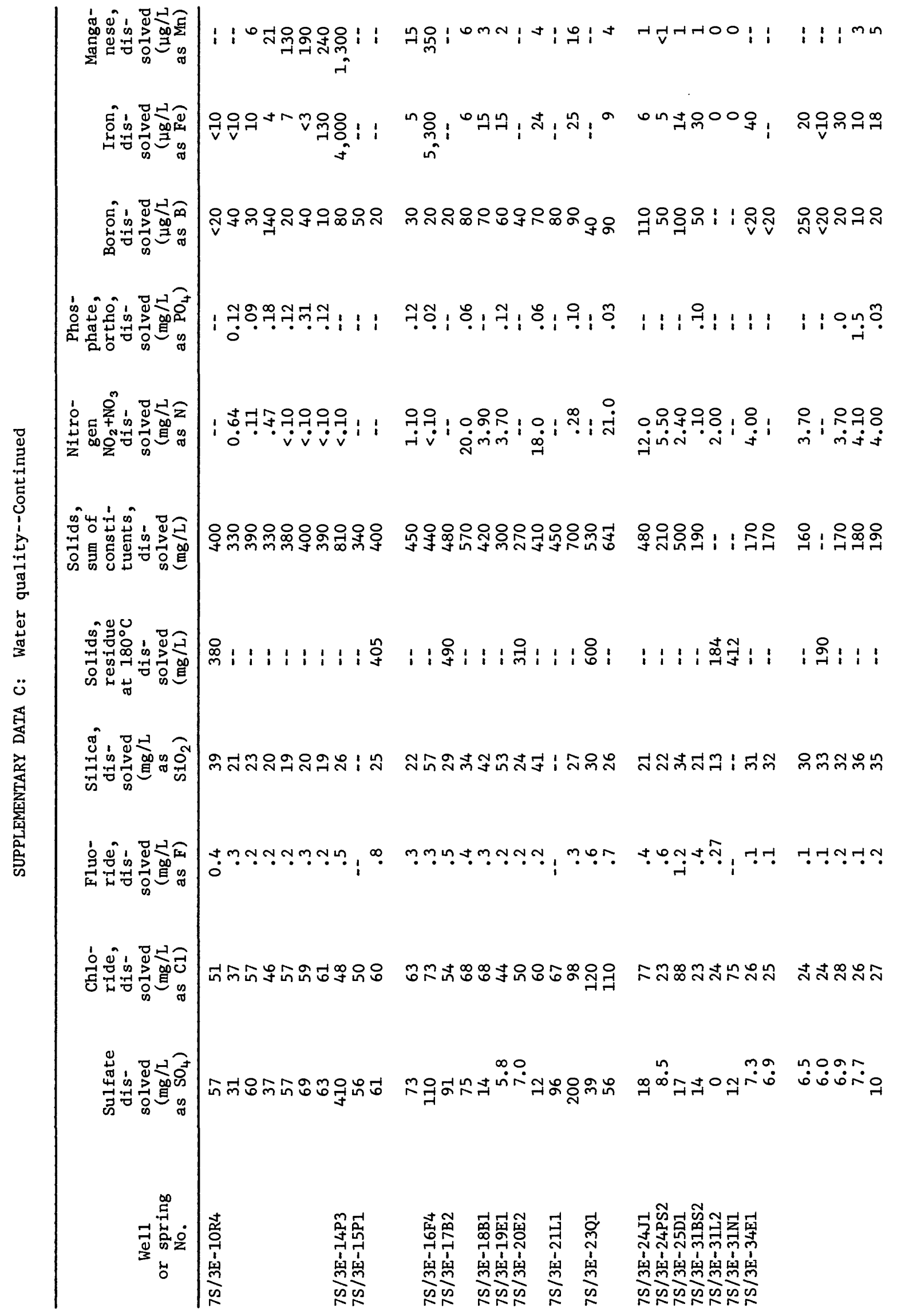




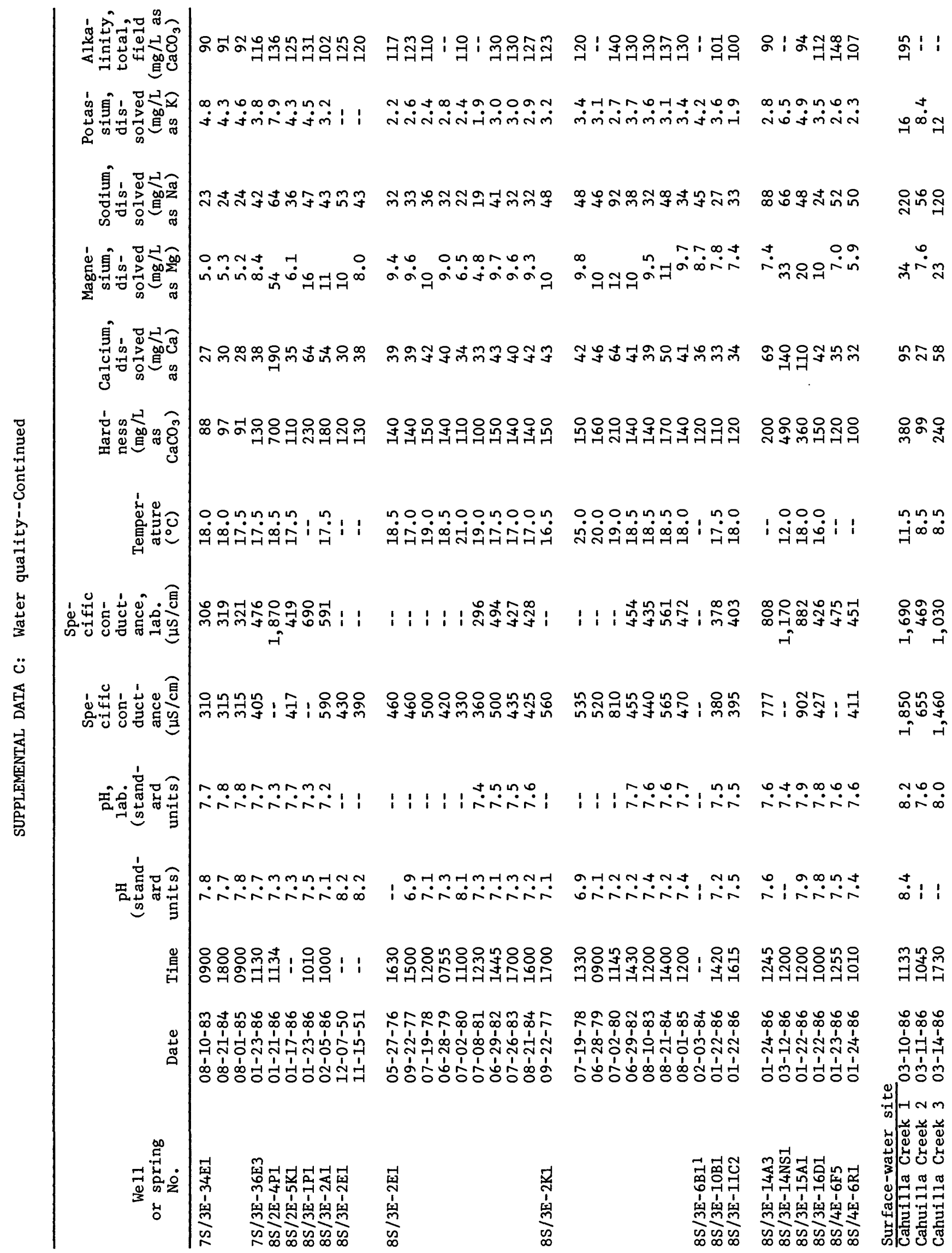




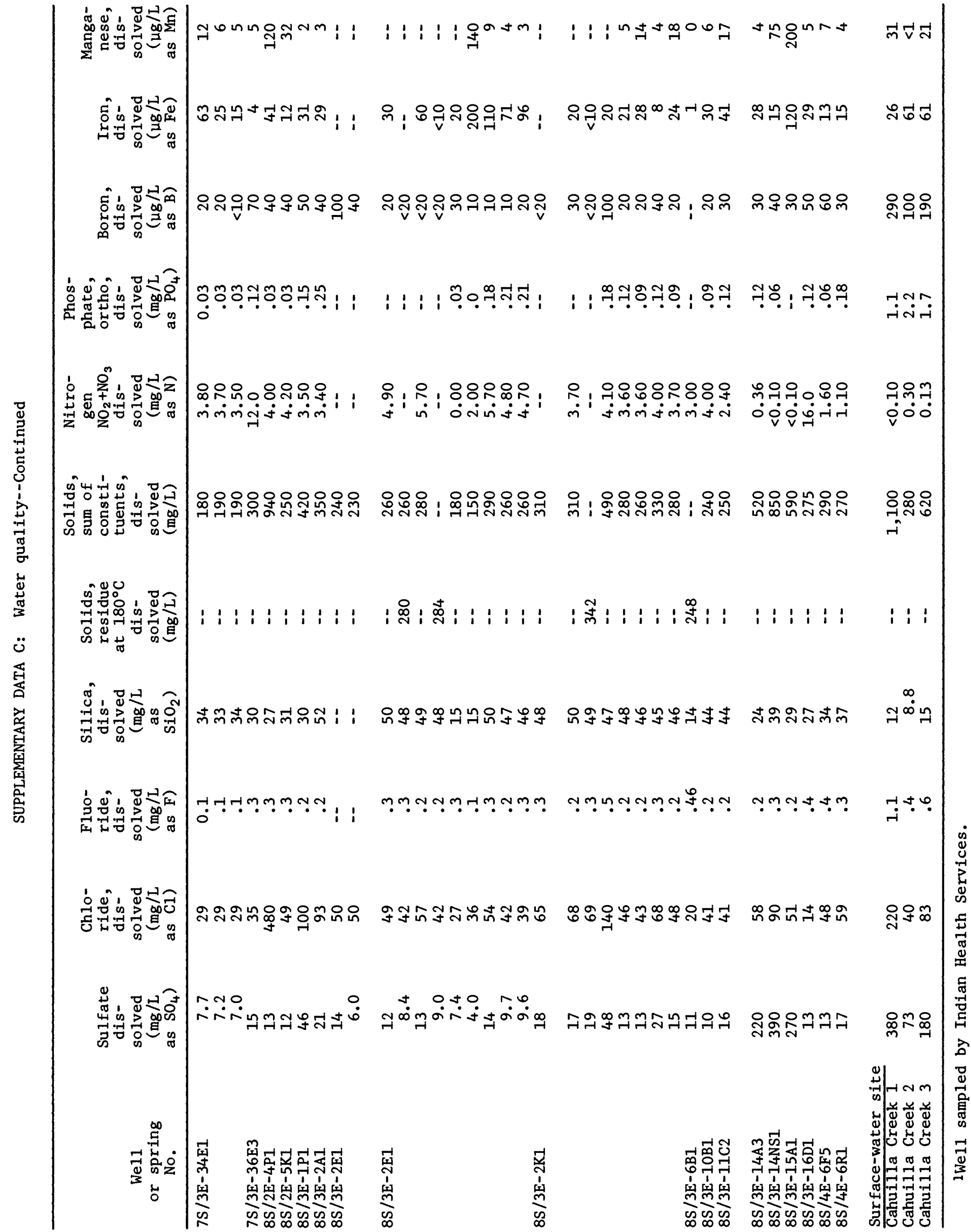

